\title{
ESTIMATIVAS DE PARÂMETROS GENÉTICOS DE CARACTERES DE PLANTA E BULBO DE CEBOLA (Allium cepa L.)
}

\author{
JOSÉ AMAURI BUSO \\ Engenheiro Agrônomo \\ EMBRAPA
}

Orientador: PROF. CYRO PAULINO DA COSTA

Dissertação apresentada á Escola Superior de Agricultura "Luiz de Queiroz", da Universidade de São Paulo, para obtenção do título de Mestre em Genética e Melhoramento de Plantas

PIRACICABA

Estado de São Paulo - Brasil

Março 1978 


\section{DEDICO}

A meu pai (in memoriam),

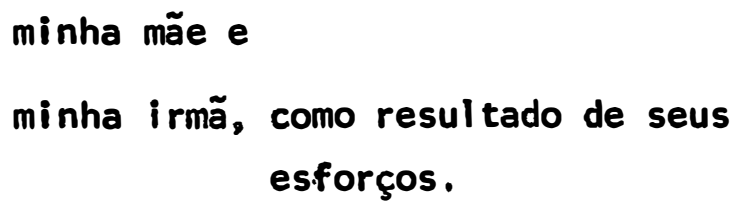

A meu irmão. 
iii.

\section{CURRICULUM VITAE}

José Amauri Buso, filho de Felisbino Buso e Dna. Amélia Deliberali Buso, nasceu em Piracicaba (SP) a 29 de outubro de 1952. Fez seus estudos em Jundiaí (SP) e diplomou-se Engenheiro-Agrônomo pela Escola Superior de Agricultura "Luiz de Queiroz", em dezembro de 1975.

Em março de 1976 iniciou o curso de Mestrado em Gené tica e Melhoramento de Plantas, também na ESALQ/USP e, no mesmo mês, foi contratado pela Empresa Brasileira de Pesquisa Agropecuária (EM BRAPA). Em março de 1978 iniciou suas atividades profissionais como pesquisador da UEPAE de Brasília, na área de Melhoramento de Hortaliças 。 


\section{AGRADECIMENTOS}

Este trabalho é o resultado da colaboração conjunta de muitas pessoas. Dessa forma, seria impossível mencionar o nome de todas que, de uma forma ou de outra, contribuiram para sua reali zação. A elas $e$. muito especialmente,

ao Prof. Dr. Cyro Paulino da Costa, pela orientação, amizade e in centivo constante:

ao Engenheiro Agrônomo MS Isaias Olívio Geraldi, pela revisão e críticas da metodologia:

ao Engenheiro-Agrônomo José Fernando Machado Menten, pela colaboração durante a parte experimental e na revisão final;

à Professora Marília Buso, pela revisão gramatical do texto original;

aos Senhores Alcides Martin. Antonio Cella, Antonio Minucci e José Guerrệro pela colaboração valiosa durante os trabalhos de cam po e de laboratório;

à Srta. M.A. Bouchardet, pela colaboração no preparo do texto original:

ao Instituto e Departamento de Genética da ESALQ/USP, na pessoa de seu Diretor, Prof. Dr. Ernesto Paterniani, pelas facilidades concedidas;

à Empresa Brasileira de Pesquisa Agropecuāria (EMBRAPA), pela oportunidade de realização do curso que ora concluímos;

à Gráfica Horizonte (Jundiaf, SP), na pessoa do Sr. Ivan Siqueira, pela confecção das capas;

aos professores e colegas do curso, pelos ensinamentos e pela amizade constante:

os nossos mais sinceros agradecimentos. 
Pág.

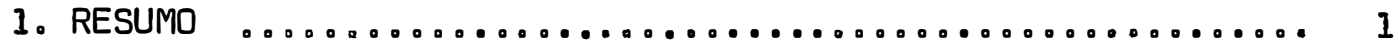

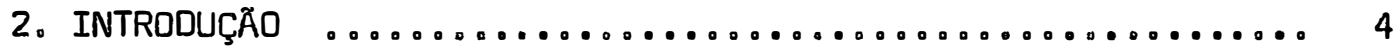

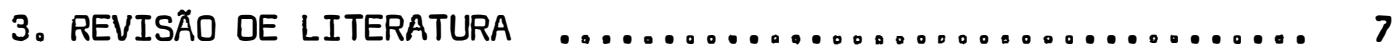

3.1 - Coeficientes de herdabilidades de caracteres de bulbo 7

3.2 - Correlações entre caracteres de bulbo e planta de ce-

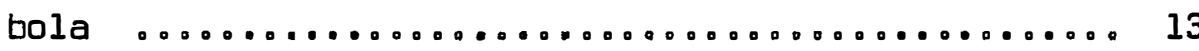

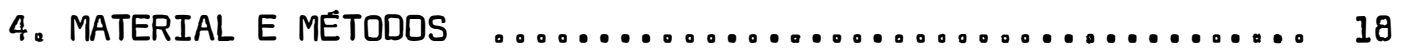

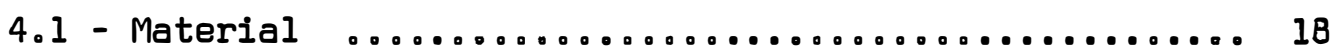

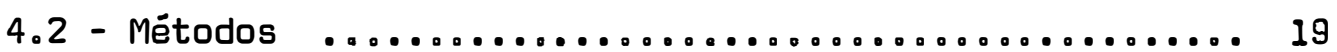

4.2 .1 - Condução do experimento ............. 19

4.2 .2 - Delineamento experimental ............ 21

4.2 .3 - Obtenção dos dados experimentais $\ldots \ldots \ldots \ldots .21$

4.2.3.1 - Caracteres avaliados ao nível de par celas o.................. 21

4.2.3.2 - Caracteres avaliados ao nível de in divíduos ................... 22

4.3 - Correlação entre os caracteres teor de sólidos solüveis das escamas externas e teor total do bulbo ... 23

4.4 - Métodos Genético-Estatísticos $\ldots \ldots \ldots \ldots \ldots \ldots \ldots \ldots$

4.4.1 - Caracteres avaliados ao nível de parcelas .. 23

4.4.2 - Caracteres avaliados ao nível de indivíduos 27

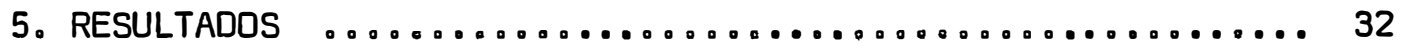

5.1 - Caracteres avaliados ao nível de parcelas ....... 32 
vi。

Pảg.

5.2 - Caracteres avaliados ao nível de indivíduos ...... 35

5.3 - Coeficiente de herdabilidade para caracteres de bulbo e planta de cebola ....................... 37

5.3.1 - Caracteres avaliados ao nível de parcelas .. 37

5.3.2 - Caracteres avaliados ao nível de indivíduos.. 40

5.4 - Correlações entre caracteres de planta e bulbo de ce-

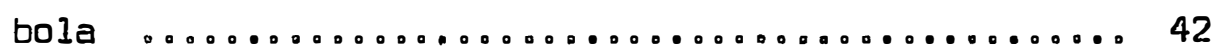

5.4.1 - Caracteres avaliados ao nível de parcelas . . 42

5.4.2 - Caracteres avaliados ao nível de indivíduos.. 44

5.5 - Gradiente do teor de sólidos solúveis do bulbo de ce-

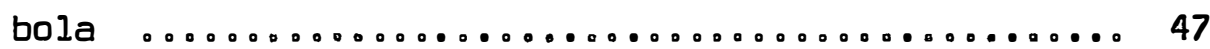

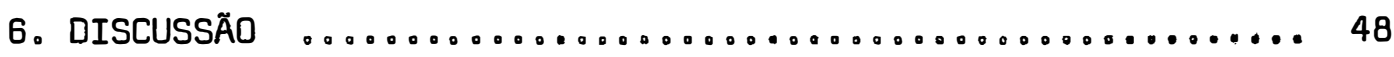

6.1 - Coeficiente de herdabilidade para caracteres avaliados ao nível de parcelas ................... 48

6.2 - Coeficiente de herdabilidade para caracteres avaliados ao nível de indivíduos ................. 56

6.3 - Correlações entre caracteres de planta e bulbo de ce-

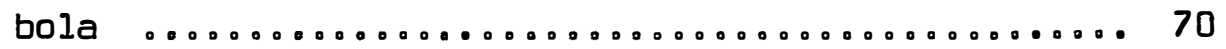

6.3 .1 - Caracteres avaliados ao nível de parcelas ... 70 6.3.2 - Caracteres avaliados ao nível de indivíduos.. 77

7. CONCLUSÕES $\ldots \ldots \ldots \ldots \ldots \ldots \ldots \ldots \ldots \ldots \ldots \ldots \ldots \ldots \ldots \ldots \ldots \ldots \ldots \ldots \ldots \ldots \ldots$

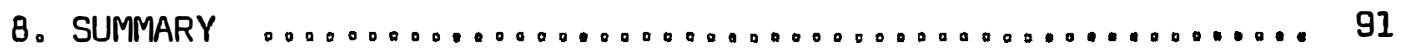

9. LITERATURA CITADA $\ldots \ldots \ldots \ldots \ldots \ldots \ldots \ldots \ldots \ldots \ldots \ldots \ldots \ldots \ldots$

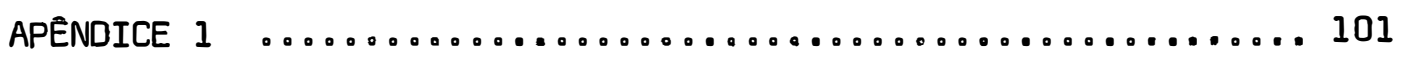

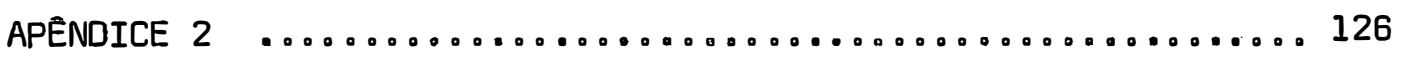


1. RESUMO

Herdabilidades e correlações genéticas e fenotípicas constituem parâmetros genético-estatisticos que caracterizam a variação genética e as associações entre caracteres de natureza poligênica. O objetivo do presente trabalho foi estimar as herdabilidades e correlações entre caracteres de planta e bulbo de cebola, para a população $C_{5}$ Baia Periforme Precoce $\times$ Red Creole. Utilizou-se de 54 progênies de meios irmãos, avaliadas em dois locais, Piracica ba e Anhembi, na época de cultivo mais favorável para a cebola, com a semeadura em maio. Os caracteres avaliados ao nível de parcelas foram produção, sobrevivência, plantas improdutivas e bulbos comerciais. Os caracteres avaliados ao nível de indivíduos, considerando-se uma amostra de dez bulbos por parcela, foram peso, diâmetro, In dice de formato e teor de sólidos solúveis. 0 delineamento experimen tal foi em blocos ao acaso, com quatro repetições. Os parâmetros ge 
néticos foram estimados através de componentes de variância e covariância. As herdabilidades dos caracteres avaliados ao nível de par celas foram estimadas considerando-se médias de progênies de meios irmãos. As herdabilidades mais elevadas foram para produção por àrea: 67,63 e $41,64 \%$, e número de plantas improdutivas: 39,92 e 52,39\%, respectivamente para Piracicaba e Anhembi. Foram positivas e significativas as correlações fenotípicas considerando-se médias de progênies, entre produção e sobrevivência, produção e número de bulbos comerciais; foi negativa entre número de bulbos comerciais e número de plantas improdutivas, para o local Anhembi. Para Piracicaba a cor relação fenotípica significativa foi positiva entre sobrevivência e número de bulbos comerciais, porém negativa entre número de bulbos comerciais e número de plantas improdutivas. As maiores correlações genéticas aditivas entre as progênies foram: entre sobrevivência e número de bulbos comerciais: 0,9375 e -0,4935, e entre número de bul bos comerciais e número de plantas improdutivas: -0,9436 e -0,8051, respectivamente para Piracicaba e Anhembi.

As maiores herdabilidades para os caracteres do bulbo foram: peso, 39,09 e 12,01\%:e teor de sólidos solúveis: 40,73 e $32,98 \%$, respectivamente para Piracicaba e Anhembi. A herdabilidade do Indice de formato foi de $99,57 \%$ para o local Anhembi. As maiores correlações fenotípicas entre caracteres ao nível de indivíduos foram entre peso e teor de sólidos solúveis: -0,8561 e -0,2685; diāmetro e índice de formato: $-0,4965$ e 0,2991. As maiores correlações genéticas para os caracteres de bulbo foram entre peso e diāmetro: 
$-0,9622$ e -0,2529; peso e teor de sólidos solúveis: $-0,6983$ e -0,3954: diâmetro e indice de formato: $-0,4175$ e $-0,6189$, respectivamente para Piracicaba e Anhembi.

0 melhoramento da cebola visando ao aumento da produ tividade é promissor, fazendo-se seleção das melhores progénies de meios irmãos ou seleção massal dentro de progênies.

A população $C_{5}$ Baia $\times$ Red Creole apresenta variabilidade genética para a maioria dos caracteres estudados. 


\section{INTRODUÇÃO}

A cebola é uma das espécies hortícolas mais polimórficas, e sua domesticação remonta a mais de 6.000 anos. A cebola. inicialmente como uma planta medicinal, e posteriormente como uma hortaliça, teve sua domesticação provavelmente baseada em seleção de caracteres de planta e bulbo através da seleção massal, feita antes do florescimento,

Os caracteres de natureza qualitativa, como a colora ção de bulbo, apresentam-se hoje bastante estudados. Porém, são raros os estudos de caracteres de natureza genética quantitativa. A seleção massal para esses caracteres tem se mostrado eficiente, como o expresso através do acentuado polimorfismo existente, observado nas inümeras cultivares, contrastantes para inúmeros caracteres de bulbo e planta, tanto em cebolas do grupo de dias longos como de dias curtos. 
A seleção massal se caracteriza por ser efetuada nos caracteres de bulbo "per se". No entanto, a característica de produ ção mais importante é a relacionada à produção de bulbos comerciais por área. Deve-se ressaltar também que existem outros caracteres de planta e bulbo que são diretamente relacionados com a produção, como peso de bulbo, sobrevivência, nümero de plantas improdutivas e outros. Com poucas exceções como a coloração de bulbo, que é um caráter qualitativo, os outros caracteres de planta e bulbo de cebola são de natureza quantitativa. 0 melhoramento genético de população, quando se trata de caracteres quantitativos, deve se basear no conhecimento de certos parâmetros genético-estatísticos, que possibilitam aumentar-se a eficiência do melhoramento da cebola para carac teres de planta e bulbo.

As herdabilidades e correlações constituem parâmetros genéticos que possibilitam estudos teóricos relativos à eficiência de diferentes esquemas seletivos, como a seleção massal, a seleção entre progênies e outros.

A herdabilidade permite caracterizar a parte genética existente na variação fenotípica total de um caráter. Já as correlações têm valor por mostrar a existência e a magnitude das associações entre os caracteres, e sua aplicação se relaciona à existên cia de possíveis respostas correlacionadas, em decorrência da seleção.

Convém ressaltar que os parâmetros genéticos, como a herdabilidade e as correlações, são dependentes da população estuda 
da, do sistema e da época de cultivo, e também dos locais considera dos.

0 presente trabalho visou conhecer a estrutura genética da população $C_{5}$ Baia Periforme Precoce $\times$ Red Creole, com relação a vários caracteres de bulbo e planta, quando cultivada em dois locais. Assim, procurou-se conhecer para cada local:

a) a variação genética aditiva presente para cada caráter;

b) o coeficiente de herdabilidade de cada caräter;

c) o progresso esperado com a seleção entre progênies de meios irmãos para alguns caracteres, e com a seleção massal estra tificada para outros;

d) as correlações genéticas e fenotípicas entre caracteres de bulbo, ao nível de individuos, e entre os outros caracteres ao nível de médias de progênies de meios irmãos;

e) procurou-se também estabelecer a correlação fenotípica entre os caracteres teor de sólidos solúveis, obtido através de técnicas não destrutivas, com o teor total de sólidos so lúveis do bulbo. 


\section{REVISÃO DE LITERATURA}

Há na literatura poucos trabalhos relacionados a estimativas de coeficientes de herdabilidades e correlações entre caracteres da cebola, usando-se progênies de meios irmãos.

\section{1 - Coeficiente de herdabilidade de caracteres de bulbo}

A cebola é uma das espécies olerícolas mais polimörficas. Existem diferenças quanto a formato, tamanho, coloração,teor de sólidos solúveis, reação a fotoperiodismo e outros caracteres do bulbo (JONES e MANN, 1963). A variação entre bulbos para tamanho. formato e teor de matéria seca sugere que esses caracteres são herdados quantitativamente. Segundo FALCONER (1964), a determinação do coeficiente de herdabilidade é um dos primeiros objetivos no estudo genético de um caráter métrico. O coeficiente de herdabilidade no 
sentido restrito foi definido cọmo o quociente entre a variância ge nética aditiva e a variāncia fenotípica de um caráter (HANSON, 1963). A importância da herdabilidade reside em que esta expressa a valida de do valor fenotípico como um guia do valor genotípico para melhoramento (FALCONER, 1964).

Segundo LONNQUIST (1965), o melhoramento de uma população por seleção depende da variação genética aditiva que está prê sente. Portanto, o coeficiente de herdabilidade serve para orientação no melhoramento sobre a quantidade relativa da variação genética que è utilizável no melhoramento (VENCOVSKY, 1969)。

Muitas decisões práticas sobre procedimentos quanto a métodos de melhoramento dependem da magnitude da herdabilidade (FAL CONER, 1964 ).

Há métodos de seleção relativamente simples e que são eficientes para selecionar efeitos genéticos aditivos. Entre es ses está a seleção massal, que possui as vantagens de ter uma dụração mínima do ciclo, oferecer oportunidade para máxima recombinação e permitir máximas intensidades de seleção (LONNQUIST, 1965). Na cebola a seleção massal tem sido extensivamente utilizada (JONES e MANN, 1963; DIAS e COSTA, 1967). Na cebola os pro gressos genéticos esperados são maiores com esse tipo de seleção, porque esta é feita antes do florescimento, para todos os caracteres importantes. Há contribuição dos dois sexos para o progresso genéti co total esperado.

0 peso do bulbo é um dos caracteres que o melhorista 
leva bastante em consideração na seleção. Estã relecionado com a produção (KNOTT, 1951). De modo geral, os autores verificam que a herdabilidade para esse carāter é baixa. Isso significa que se trata de um caräter altamente influenciado pelo ambiente. Segundo KNOTT (1951), o peso do bulbo é afetado entre outros fatores, pelo tamanho da muda, e principalmente pela competição entre plantas para nu trientes e níveis de água.

NAKAMURA (1959) obteve na cultivar Senshuki uma herdabilidade de $0 \%$ para peso de bulbo, estimada por regressão entre progenitores e respectivas progènies.

Estimada por regressão entre progenitores e respecti vas progênies autofecundadas, a herdabilidade para peso de bulbo va riou entre $0 \%$ e $11 \%$ em quatro populações da cultivar de dias longos Yellow Sweet Spanish e duas da cultivar White Sweet Spanish (McCOLLUM, 1966).

Utilizando regressão entre progenitores e respectivas progênies de meios irmãos e também componentes da variância. Mc COLLUM (1968) obteve estimativas de herdabilidade para peso de bulbo de 0 e $28 \%$ respectivamente, para outras populações da cultivar White Sweet Spanish. McCOLLUM (1971) também estimou a herdabilidade para peso de bulbo em dez populações de cebola, através de regressão entre progenitores e respectivas progênies e usando componentes da variāncia. A herdabilidade variou entre 0 e $22 \%$

A herdabilidade tem valor primário como método de quantificar o conceito relativo de facilidade ou dificuldade de ob- 
ter progresso por seleção em programa de melhoramento (HANSON,1963). Assim, pode-se admitir que peso de bulbo é um caráter difícil de ser modificado por seleção "per se" devido a sua baixa herdabilidade.En tretanto, ocorrem cultivares dentro do grupo de cebola de dias curtos com bulbos grandes, como a cultivar Texas Grano, e de bulbos pequenos, como a cultivar Red Creole, em iguais condições de cultivo (JONES E MANN, 1963)。

0 formado do bulbo tem sido representado como um índice pela relação entre altura e diâmetro de bulbo. Assim, para bul bos redondos, o indice seria próximo ou igual a 1, e para bulbos cha tos próximo ou igual a 0,5. Segundo MAGRUDER et alii (citado por Mc COLLUM, 1966), a altura do bulbo seria a medida que vai da inserção das raízes até a constrição do pescoço, no ponțo onde a curvatura muda de convexa para côncava. 0 diâmetro seria a maior distância en tre os lados opostos do bulbo, em um ângulo reto à medida da altura.

A variação fenotípica do formato do bulbo e de suas componentes altura e diâmetro, sugerem que esses caracteres são her dados quantitativamente (McCOLLUM, 1971)。

Para diámetro de bulbo a herdabilidade variou entre 0 e $27 \%$, estimada por regressão ou por componentes da variância, pa ra dezessete populações de cebolas de dias longos (McCOLLUM, 1966, 1968 e 1971)。

Para o Índice de formato de bulbo, isto é, a relação entre altura e diâmetro, NAKAMURA (1959) estimou uma herdabilidade de 0,32 , utilizando-se de regressão entre progenitores e respectivas 
progênies. Já para seis populações de cebola de dias longos, a herdabilidade para a relação altura e diâmetro variou entre 0,33 e 0,67 (McCOLLUM, 1966). Para outras populações de cebolas, McCOLLuM(1968) obteve uma hẹrdabilidade estimada entre 0,28 e 0,95 para o índice de formato de bulbo. Também McCOLLUM (1971) estimou a herdabilidade para o índice de formato de bulbo de 0,89 e 0,62 , obtida respectiva mente por regressão e componentes da variāncia.

O conhecimento da herdabilidade pode ser útil ao melhorista ao predizer a efetividade de seleção para um dado caräter. Segundo FALCONER (1964) a herdabilidade é uma propriedade não somen te de um caráter, mas de uma população e do ambiente ao qual os indivíduos estão sujeitos. Observa-se que a herdabilidade para a rela ção entre altura e diâmetro do bulbo é média ou alta para todas as populações estudadas, sugerindo ser este um caráter relativamente fạ cil de ser modificado por seleção.

O teor de matéria seca vem a ser outro caráter bastante variável no bulbo de cebola, entre cultivares e também entre bulbos dentro das cultivares.

Segundo JONES e MANN (1963) as cultivares de cebola têm um teor de matéria seca variável entre 4 e $25 \%$.

Os carbohidratos constituem a maior parte da matéria seca do bulbo de cebola (JONES e MANN, 1963). Segundo BACON (1957), os carbohidratos solúveis em água no bulbo de cebola constituem-se de frutose, glucose e oligossacarídeos.

Como teor de matéría seca e teor de sólidos solúveis 
do bulbo são altamente correlacionados, em trabalhos de melhoramento utiliza-se o teor de sölidos solúveis por ser mais prático. Um refratômetro de campo pode fornecer rapidamente, por leitura direta, a porcentagem de sölidos solúveis (brix) do extrato do bulbo (MANN e HOYLE, 1945).

Segundo WARID (citado por McCOLLUM, 1968), o teor de sólidos solúveis no bulbo apresenta alta herdabilidade. Sugeriu-se que, possivelmente, de quatro a dez pares de genes estão envolvidos nas diferenças entre fenótipos contrastantes. McCOLLUM (1968) verificou também alta herdabilidade para teor de sólidos solúveis, esti mada por regressão e por componentes da variância.

A importância do teor de sólidos solúveis ẽ que ele está relacionado com o rendimento industrial da desidratação de cebola e também com perdas por apodrecimento durante armazenamento de bulbos (JONES E MANN, 1963).

Como a resposta à seleção praticada para um caráter depende da herdabilidade do carāter na geração do qual os progenito rés são selecionados (FALCONER, 1964), pode ser fácil de se modificar por seleção o teor de sólidos solúveis. O teor de matéria seca e sōlidos solúveis é variável também dentro do bulbo. Segundo ZELLER (citado por MANN e HOYLE, 1945), varia a concentração de açüca res crescendo do exterior para o interior e do ápice para a base do bulbo. Os oligosacarídeos estão distribuídos em gradiente nos bulbos maduros de cebola. As escamas internas possuem maior teor de oligosacarídeos que as escamas externas, e há maior teor na base da 
escama que em seu ápice (BACON, 1957)。

MANN e HOYLE (1945) observaram que a matéria seca au menta das escamas externas para as internas. E também maior o teor de sólidos solúveis no centro e base do bulbo que nas escamas exter nas, segundo MELO et alii (1975), para várias cultivares de cebola. A cultivar Red Creole apresentou um brix de 7,8 para a escama exter na e uma média para todo o bulbo de 10,4, e a cultivar Baia do Cedo apresentou 5,8 e 7,7 respectivamente (MELO et alii, 1975)。

\section{2 - Correlações entre caracteres de bulbo e planta de cebola}

As variações que ocorrem em populações segregantes são atribuídas a três fatores principais, a saber: efeitos ambientais, efeitos genéticos aditivos e efeitos genéticos não aditivos, devido à interação intra-alélica (dominância) e à interação inter-alélica (epistasia). Quando cada um destes efeitos varia conjuntamente, eles dão origem às respectivas covariâncias e conduzem à exis tência de correlação entre caracteres. Das correlações possíveislfẹ notípica, genética e ambiental), apenas a correlação genética aditî va expressa uma inter-relação herdável (ROBINSON et alii, 1951)。

Segundo FALCONER (1964), a correlação genética é cau sada principalmente pela pleiotropia e, transitoriamente, pela liga ção gênica, especialmente em indivíduos resultantes de cruzamentos divergentes. A importância do estudo da correlação entre caracteres está em que ela pode indicar como a seleção para um caráter poderá 
causar mudanças em outros caracteres, simultaneamente.

Segundo DEMPSTER (1963), se a correlação genética en tre dois caracteres é alta, algumas vezes pode ser útil modificar um caráter por seleção em outro caráter. As circunstâncias favoráveis são alta herdabilidade e facilidade de seleção para o caráter a ser selecionado, e alta correlação genética entre os dois caracteres.

As correlações entre caracteres do bulbo e planta de cebola variam conforme a população e a cultivar considerada. As cor relações genéticas e fenotípicas entre peso e diâmetro de bulbo foram positivas, segundo McCOLLUM (1966, 1968 e 1971).

As correlações fenotípicas entre peso e índice de for mato de bulbo foram negativas. Foram nulas ou negativas as correlações genéticas (McCOLLUM, 1966, 1968 e 1971). A correlação fenotípI ca negativa entre peso e índice de formato foi confirmada por KOBA$\mathrm{BE}(1968)$ 。

Entre Indice de formato e diâmetro de bulbo, as correlações fenotípicas foram negativas: as correlações genéticas foram também negativas, segundo McCOLLUM (1966, 1968 e 1971)。

OWENS (citado por McCOLLUM, 1968) observou uma correlação fenotípica pequena, porém não significativa, entre peso e teor de sólidos solúveis do bulbo. Por outro lado, McCOLLUM (1968) observou uma correlação fenotípica positiva e significativa entre peso e teor de sólidos solúveis, na cultivar White Sweet Spanish. A correlação genética aditiva foi de valor negativo. 
A correlação de teor de sōlidos solúveis com diâmetro de bulbo mostrou ser positiva quando fenotípica, e negativa quan do estimada geneticamente (McCOLLUM, 1968).

Não ocọrreu correlação fenotípica entre peso e teor de matéria seca do bulbo em oito cultivares de cebola, segundo MANN e HOYLE (1945), exceto para uma cultivar, onde foi negativa.

Segundo SCHWEISGUTH (1973) foi negativa a correlação fenotípica entre teor de matéria seca e produtividade.

Correlação fenotĩpica positiva entre teor de matéria seca do bulbo inteiro e teor de sólidos solúveis das escamas externas, medidas por refratōmetro, foi observado por MANN e HOYLE(1945) e WARID (citado por McCOLLUM, 1968). Por outro lado, uma correlação fenotípica positiva foi observada por FOSKETT e PETERSON (1950) en tre índice de refração (leitura de refratômetro) e teor de matéria seca.

A correlação entre índice de refração e apodrecimento durante o armazenamento de bulbos foi negativa (FOSKETT e PETERSON, 1950). Constataram haver melhor qualidade de armazenamento para cultivares que apresentavam alto teor de matéria seca.

As cultivares de cebola podem ser classificadas como de dias longos, intermediärios e curtos, segundo sua reação para a formação do bulbo, em relação às exigências de fotoperiodismo (J0NES e MANN, 1963). Para grupos de dias longos ou dias curtos, a maturidade da cebola pode ser expressa em tipos precoces ou tardios. Segundo NAKAMURA e TERABUM (1956), há correlação genética positiva 
entre maturidade e peso de bulbo. Também ZIMMERMANN (1973) obteve uma correlação genética positiva entre os dois caracteres, tanto entre progênies de meios irmãos como entre progênies $S_{1}$, na cultivar Barreiro. A correlação fenotípica foi positiva para os dois tipos de progênies.

Uma correlação genotípica negativa entre maturidade e produtividade foi observada por SCHWEISGUTH (1973), em três ensaios anuais sucessivos.Este resultado foi confirmado por DOWKER et $a Z_{i}$ (1976) em 84 famílias de uma população panmítica. Para progênies $S_{3}$, existe correlação genética negativa entre os dois caracteres, segundo DOWKER et alii (1976). O mesmo autor observou haver cor relação fenotípica e genética positiva entre população de plantas por unidade de área e produção por área. Correlações genéticas e fe notípicas negativas entre populações de plantas por unidade de área e maturidade foram observadas por DOWKER et alii (1976), entre progênies $\mathrm{S}_{3}$.

ZIMMERMANN (1973) observou que há correlação fenotipica e genética positiva entre maturidade e plantas improdutivas,pa ra progênies $S_{1}$. Para progênies de meios irmãos, a correlação fenotípica foi não significativa e a genética foi positiva. 0 mesmo autor observou correlação fenotípica e genética negativa entre os caracteres incidência de plantas improdutivas e florescimento prematu ro.

Há também uma correlação genética positiva para os caracteres plantas improdutivas e perfilhamento de bulbos, conside- 
rando-se progênies de meios irmãos (ZIMMERMANN, 1973).

Pode-se admitir que, fazendo-se a seleção para um ca ráter de bulbo ou planta de cebola, possivelmente se terá mudanças em outros caracteres, devido às correlações genéticas existentes. 
18.

4. MATERIAL E METODOS

\section{1 - Material}

0 material utilizado no presente trabalho constitui-se de 54 progênies de meios irmãos da geração $C_{5}$ originária do cru zamento das cultivares Baia Periforme Precoce com a Red Creole, e de duas testemunhas indicadas na relação abaixo:

- cultivar Red Creole;

- cultivar Composto Baia SMP-V.

As gerações que antecederam a $C_{5}$ foram mantidas por seleção massal em plantios na ëpoca mais favorável de cultivo. Somente selecionaram-se os caracteres de bulbo individual como formato, coloração, e indiretamente, maior teor de sólidos solúveis "in vivo", isto é, eliminaram-se bulbos de baixa conservação (brotados e podres). A obtenção das progênies de meios irmãos (geração $C_{5}$ ), 
deu-se a partir de plantas individuais, da população $C_{4}$, de polinização livre.

Como a autofecundação causa uma queda acentuada no vigor da muda (ZIMMERMANN, 1973), considerou-se que todas as mudas transplantadas provieram de sementes de intercruzamento. No transplante tomaram-se apenas as mudas vigorosas, procedimento normal em programas de melhoramento e no cultivo comercial.

\section{2 - Métodos}

\subsection{1 - Condução do experimento}

As progênies de meios irmãos e as testemunhas foram avaliadas em dois locais a saber: Campo Experimental do Instituto de Genética da Escola Superior de Agricultura "Luiz de Queiroz", em Pí racicaba, solo de terra roxa misturada e na Estação Experimental de Anhembi, do mesmo Instituto, Município de Piracicaba, em solo areno so.

O sistema de cultivo utilizado foi o transplante. As mudas foram produzidas em canteiros, previamente adubados, utilizan do-se $5 \mathrm{~g}$ de semente por $\mathrm{m}^{2}$ de canteiro. A semeadura deu-se em $12 /$ 05/77 e o transplante em 06/07/77 e 07/07/77, para Piracicaba e Anhembi, respectivamente. O transplante das mudas no campo foi reali zado tomando-se ao acaso, 40 mudas vigorosas de cada tratamento,pro gênie ou testemunha, que constituiram uma parcela.

A adubação química utilizada constituiu-se de $50 \mathrm{~g}$ 
por metro de sulco, da fórmula 4:30:20. Posteriormente, foram feitas adubações nitrogenadas em cobertura, quando necessārio.

Como bordadura, utilizaram-se 2 linhas nas laterais do campo, e dois metros de linha na cabeceira \& no final de cada li nha, contendo os tratamentos.

Os tratos culturais utilizados durante o desenvolvimento das plantas foram os normais e usuais para a cultura da cebola. Assim, fizeram-se pulverizações semanais com inseticidas e fungicidas, seguindo o procedimento normal dos programas de melhoramen to de cebola do Instituto de Genética. A irrigação em Piracicaba foi por infiltração e em Anhembi foi por aspersão, em frequência de uma ou duas vezes por semana, a fim de manter a umidade ideal do solo e o bom desenvolvimento vegetativo das plantas de cebola.

A colheita dos bulbos foi realizada quando no mínimo 80\% das plantas das parcelas apresentavam maturação do bulbo, expres so pelo tombamento da haste e inicio de secamento das folhas. Na co lheita, foram avaliadosos caracteres ao nivel de parcelas.

Cada parcela foi colhida separadamente, em sacos de malha grossa de "nylon", e transportada para galpões ventilados, on de se procedeu à pesagem de cada uma delas.

Posteriormente, de cada parcela foi retirada uma amos tra de dez bulbos, após o que se fizeram determinações dos caracteres ao nivel de indivíduos. 


\subsection{2 - Delineamento Experimental}

Para cada local adotou-se o delineamento em blocos ao acaso, segundo PIMENTEL GOMES (1973). As progênies de meios irmãos constituiram as parcelas.

Cada parcela constituiu-se de $2,00 \mathrm{~m}^{2}$ de ärea, para um "stand" ideal de 40 plantas, no espaçamento de $50 \mathrm{~cm}$ entre linhas e $10 \mathrm{~cm}$ entre plantas na linha, para uma população ideal de 200.000 plantas por hectare.

\section{2 .3 - Obtenção dos dados experimentais}

De cada local foram tomados dados de caracteres ao nível de parcelas e de outros caracteres ao nível de indivíduos.

\subsubsection{1 - Caracteres avaliados ao nivel de parcelas}

Em cada parcela foram obtidos dados dos seguintes ca racteres, avaliados ao nível de parcelas:

a) produção: representa o peso de bulbos comerclais, por $2 \mathrm{~m}^{2}$ de àrea, após terem sido eliminadas as raízes e folhas:

b) sobrevivência: é o número de plantas remanescentes, por oca sião da colheita, para um número ideal de 40 plantas em $2 \mathrm{~m}^{2}$ de área;

c) número de plantas improdutivas: considerou-se o número de plantas que por ocasião da colheita, não formaram bulbos, ou formaram bulbos sem valor comercial; 
d) nümero de bulbos comerciais: expresso pelo nümero de plantas que resultaram em bülbos de qualidáde desejável no comércio.

\subsubsection{2 - Caracteres avaliados ao nivel de indivi duos}

De cada parcela foi tomada ao acaso uma amostra de dez bulbos, e fizeram-se determinações individuais dos seguintes ca racteres:

a) peso de bulbo: expresso em gramas, após eliminação de folhas e raízes;

b) diâmetro de bulbo: em cm, conforme definição de MAGRUDERlci tado por McCOLLUM, 1966):

c) Índice de formato: expresso pela relação entre altura e diạa metro de bulbo;

d) teor de sólidos solūveis: de cada bulbo foi retirado um dis co de aproximadamente $2 \mathrm{~cm}$ de diâmetro, contendo 1 ou 2 escamas externas, na região de maiọr diâmetro do bulbo. A seguir, essa amostra de escamas foi esmagada em um espremedor e uma amostra de suco foi colocada em refratômetro de campo, marca Zeiss. A leitura no re fratômetro forneceu o teor de sólidos solüveis, expresso em graus brix (porcentagem de sólidos solúveis).

Limpou-se com papel absorvente o refratômetro e o es premedor após cada leitura, procurando-se eliminar uma provável fon te de erro. A utilização desse método não destrutivo permite a se- 
leção dos bulbos de maior teor de sólidos solúveis, que irão compor a população selecionada.

Os procedimentos de leitura de brix pelo método não destrutivo seguiram, em linhas gerais, a metodologia relatada em FOS KETT \& PETERSON (1950).

\section{3 - Correlação entre os caracteres teor de sölidos solüveis das escamas externas e teor total do bulbo}

Foi retirada da população uma amostra de 80 bulbos, ao acaso, e nestes foram feitas determinações do teor de sólidos solúveis para diferentes partes do bulbo. Cada bulbo foi amostrado em quatro regiões: externa, compreendendo as duas primeiras escamas na região de maior diâmetro; basal, compreendendo a zona de crescimento do bulbo: apical, e central, compreendendo o centro do bulbo. As amostras contendo aproximadamente $2 \mathrm{~cm}$ de diâmetro foram esmagadas e a leitura fez-se em um refratômetro marca Zeiss, de campo.

A leitura do teor de sólidos solúveis, considerando-se o bulbo inteiro, foi feita de uma amostra obtida da secção longitudinal do bulbo, compreendendo todas as regiões do mesmo.

\section{4 - Mëtodos Genētico-Estatisticos}

\subsection{1 - Caracteres avaliados ao nivel de parcelas}

As análises de variância, para cada caräter avaliado ao nível de parcelas, foram feitas separadamente para cada local, de 
acordo com a metodologia relatada em COCHERHAM (1963). Todos os caracteres expressos em nümero foram transformados em $\sqrt{\text { numero }}$ ou

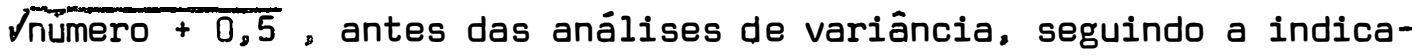
ção de STEEL e TORRIE (1960). O modelo da análise de variância com as respectivas esperanças dos quadrados médios, está apresentada na tabela 1 , considerando-se um local.

Cada componente dos quadrados médios foi estimado do seguinte modo, para cada local:

$$
\begin{aligned}
& \sigma_{p}^{2}=\frac{Q_{2}^{\prime}-Q_{1}^{\prime}}{r}, \\
& \sigma_{e}^{2}=Q_{1}^{\prime}
\end{aligned}
$$

De acordo com essa metodologia, a $\sigma_{p}^{2}$ é igual a $\frac{1}{4}$ da $\hat{\sigma}_{A}^{2}$ (COCHERHAM, 1963; FALCONER, 1964), sendo $\hat{\sigma}_{A}^{2}$ a estimativa da variância genética aditiva do caráter considerado, ao nível de parcelas.

Os coeficientes de herdabilidade foram estimados, pa ra cada local, considerando-se seleção entre médias de progênies de meios irmãos, como segue:

$$
\hat{h}^{2}=\frac{\frac{1}{4} \hat{\sigma}_{A}^{2}}{\hat{\sigma}_{F}^{2}}
$$

onde, $\hat{h}^{2}=$ coeficiente de herdabilidade do caráter considerado; $\hat{\sigma}_{A}^{\prime}=$ variância genética aditiva presente, à nível de parcelas: 
$\tilde{\sigma}_{\bar{F}}^{2}=$ variância fenotípica entre médias de progênies de meios irmãos. Quando o nümero.de prog̣ệnies é suficientemente grande, a $\hat{\sigma}_{\bar{F}}^{2}$ corresponde a

$$
\hat{\sigma}_{F}^{2}=\tilde{\sigma}_{p}^{2}+\frac{\dot{\sigma}_{e}^{2}}{I}
$$

(VELLO e VENCOVSKY, 1974), considerando-se um local.

0 progresso genētico eșperado com a seleção $\left(\Delta G^{\prime}\right)$ foi estimado para cada caräter considerando-se seleção entre médias de progênies de meios irmãos, para cada local, como segue:

$$
\hat{\Delta G^{\prime}}=i \cdot \frac{\frac{1}{4} \hat{\sigma}_{A}^{2}}{\sqrt{\sigma_{\frac{2}{F}}^{2}}} .
$$

onde, $\hat{\sigma}_{A_{i}}^{2}$ e $\hat{\sigma}_{\bar{F}_{i}^{2}}^{2}$ têm os mesmos significados anteriormente descritos, e $i=$ coeficiente associado à intensidade de seleção (FALCONER, 1964).

Para esses caracteres considerou-se uma intensidade de seleção de $10 \%$, à qual corresponde o coeficiente de 1,76 (FALCDNER, 1964)。

0 coeficiente de variação genética ( C.V.gen $\%$ ) foi cal culado, para cada local, pelo seguinte processo:

$$
C \cdot V \cdot \text { gen }^{\%}=\frac{\sqrt{\tilde{\sigma}_{p_{i}^{\prime}}^{2}}}{\bar{x}^{\prime}} \times 100 \text {, }
$$

onde, $\bar{x}^{\prime}=$ média familiar do caráter, para cada local. 
As análises de covariância entre dois caracteres $x^{\prime} e$ $y^{\prime}$ foram feitas segundo a metodologia relatada em KEMPTHORNE(1966), da maneira exposta em 4.2.4.2. Apenas não se obteve a fonte de variação dentro de parcelas.

Obtidos os componentes dos produtos médios, estimaram-se os coeficierites de correlação fenotípica e genética segundo as metodologias relatadas em QUEIROZ (1969) e FALCONER (1964). Segundo essas metodologias; tem-se, para cada local:

$$
\hat{r}_{A\left(x^{\prime}, y^{\prime}\right)}^{\prime}=\frac{\frac{1}{4} \operatorname{cov}_{A\left(x^{\prime}, y^{\prime}\right)}}{\sqrt{\left(\frac{1}{4} \hat{\sigma}_{A x^{\prime}}^{-2}\right)\left(\frac{1}{4} \hat{\sigma}_{A y^{\prime}}^{\prime}\right)}},
$$

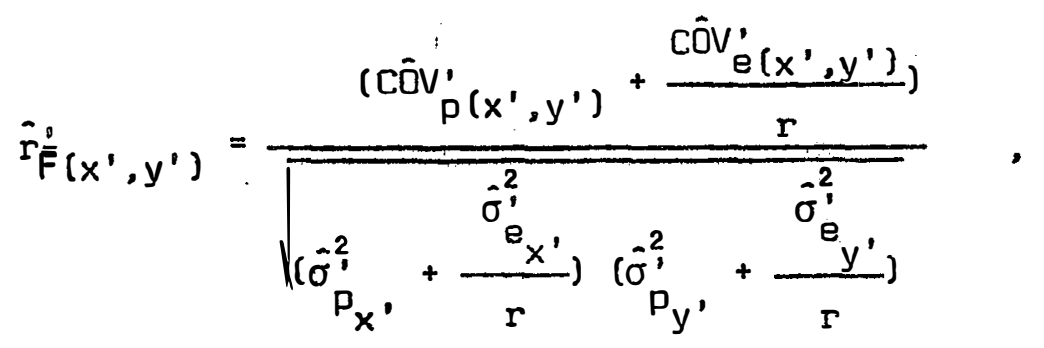

onde, $\hat{r}_{A\left(x^{\prime}, y^{\prime}\right)}=$ coeficiente de correlação genética aditiva entre os caracteres $x^{\prime} e y^{\prime}$, entre progênies de meios irmãos :

$$
\begin{aligned}
\hat{r}_{\bar{F}}^{\prime}\left(x^{\prime}, y^{\prime}\right)= & \text { coeficiente de correlação fenotfipica entre os ca- } \\
& \text { racteres } x^{\prime} \text { e } y^{\prime} \text {, entre médias de progênies; } \\
\operatorname{côv}_{A\left(x^{\prime}, y^{\prime}\right)=} & \text { covariância genética aditiva entre os caracteres } \\
& x^{\prime} \text { e } y^{\prime}, \text { ao nível de parcelas: }
\end{aligned}
$$




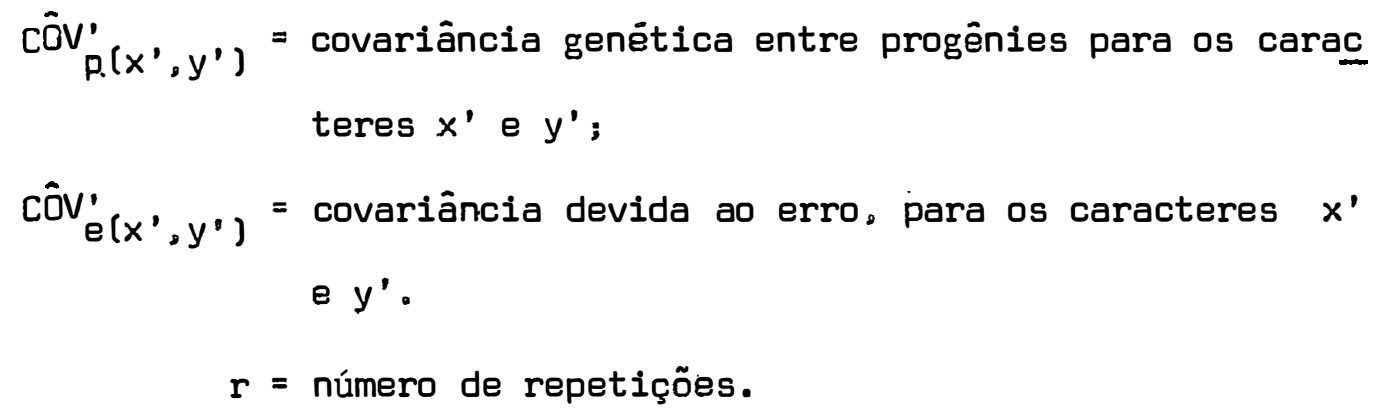
teres $x^{\prime}$ e $y^{\prime}$;

$\operatorname{côv}_{e}^{\prime}\left(x^{\prime}, y^{\prime}\right)=$ covariância devida ao erro, para os caracteres $x^{\prime}$ e $y^{\prime}$.

$r$ = número de repetições.

Os demais termos já foram definidos anteriormente.

Os coeficientes de correlação fenotípica, tiveram sua significância avaliada pelo teste de $t$, após transformação de $\hat{r}_{\bar{F}}$ em $z\left(\hat{r}_{\bar{F}}^{\prime}\right)$, segundo PIMENTEL GOMES (1973).

\subsection{2 - Caracteres avaliados ao nivel de individuos}

Para a obtenção das estimativas dos parâmetros genéticos, as análises de variância para cada caráter ao nível de indivíduos, foram feitas separadamente para cada local, de acordo com a metodologia relatada por VENCOVSKY (1969). O esquema da análise de variância, considerando-se um local, encontra-se na tabela 2.

Cada componente dos quadrados médios foi estimado con siderando-se cada local, da seguinte forma:

$$
\begin{aligned}
& \tilde{\sigma}_{p}^{2}=\frac{Q_{3}-Q_{2}}{r K}, \\
& \bar{\sigma}_{e}^{2}=\frac{Q_{2}-Q_{1}}{K}, \\
& \bar{\sigma}_{d}^{2}=Q_{1}
\end{aligned}
$$


Segundo essa metodologia tem-se que $\tilde{\sigma}_{p}^{2}$ é igual a $\frac{1}{4}$ da $\hat{\sigma}_{A}^{2}$ (COCHERHAM, 1963; FALCONER, 1964); sendo $\hat{\sigma}_{A}^{2}$ a variância genética aditiva do caráter considerado.

Os coeficientes de herdabilidade, no sentido restrito, e ao nível de indivíduos, foram calculados, para cada local, da seguinte forma:

$$
\bar{h}^{2}=\frac{\hat{\sigma}_{A}^{2}}{\hat{\sigma}_{F}^{2}},
$$

onde, $\hat{\sigma}_{A}^{2}=$ variância genétiça aditiva, presente para cada local, ao nível de indivíduos:

$$
\begin{aligned}
\hat{\sigma}_{F}^{2}= & \text { variância fenotípica, para cada local, e onde } \hat{\sigma}_{F}^{2}=\hat{\sigma}_{d}^{2}+ \\
& +\hat{\sigma}_{\mathrm{e}}^{2}+\hat{\sigma}_{\mathrm{p}}^{2}
\end{aligned}
$$

0 progresso genético esperado com a seleção $(\Delta G)$, foi estimado considerando-se dols esquemas seletivos, como segue, para cada local:

$$
\begin{aligned}
& \hat{\Delta G}_{1}=i_{1} \frac{\hat{\sigma}_{A}^{2}}{\sqrt{\sigma_{F}^{2}}} \\
& \hat{\Delta G}_{2}=i_{2} \frac{\frac{3}{4} \tilde{\sigma}_{A}^{2}}{\sqrt{\sigma_{d}^{2}}}
\end{aligned}
$$

onde, $\Delta \hat{G}_{1}=$ progresso genético esperado com a seleção massal estratrificada, sendo cada bloco um estrato, em ambos os sexos: 


\begin{abstract}
$\hat{\Delta G}_{2}=$ progresso genético esperado com a seleção massal estratificada, sendo cada parcela um estrato, em ambos os se xos:

$i_{1}$ e $1_{2}=$ coeficientes associados às intensidades de seleção (FAL CONER。 1964 ).
\end{abstract}

No presente trabalho considerou-se para $\hat{\Delta G}_{1}$ uma inten sidade de seleção de $20 \%$ e para $\hat{\Delta G}_{2}$ uma intensidade de seleção de $20 \%$ às quais correspondem os coeficientes de 1,40 (FALCONER, 1964) e de 1,27 (FISHER e YATES, 1971, tabela $x x$ ), respectivamente para $\hat{\Delta G}_{1}$ e $\hat{\Delta G}_{2}$. Os demais componentes, isto $\dot{e}_{0} \hat{\sigma}_{A}^{2}, \hat{\sigma}_{F}^{2}$ e $\hat{\sigma}_{d}^{2}$, têm os mesmos significados anteriormente descritos. 0 progresso genético espe rado foi calculado como $\hat{\Delta G}$, obtido pela divisão do $\Delta \bar{G}$ pela média do carāter na população, e o resultado dessa divisão sendo multiplicado por 100 .

Calculou-se o coeficiente de variação genética(C.V. gen \%) para cada local, da seguinte forma:

$$
C . V \text {.gen } \%=\frac{\sqrt{\bar{\sigma}_{p}^{2}}}{\bar{x}} \times 100 \text {, }
$$

onde: $\bar{x}=$ média do caráter, para cada local.

As análises de covariância entre dois caracteres $x \mathrm{e}$ y foram feitas de acordo com a metodologia relatada por KEMPTHORNE (1966), em blocos ao acaso. Inicialmente fez-se a análise da variân cia da soma $u$ de dois caracteres, $x$ e y, para cada local, segundo os processos citados anteriormente. O produto médio entre os carae- 
teres foi obtido para cada fonte de variação e para cada local, a partir do quadrado médio, da soma dos caracteres e dos quadrados médios individuais de cada caráter, da seguinte forma:

$$
P M_{(x, y)}=\frac{1}{2}\left(Q M_{u}-Q M_{y}-Q M_{x}\right)
$$

onde, $P M_{(x, y)}=$ produto médio entre os caracteres $x$ e $y$; $Q M_{u}=$ quadrado médio de $u$, onde $u=x+y$; $Q M_{y}=$ quadrado médio para o caráter $y:$ $Q M_{X}=$ quadrado médio para o caráter $x_{0}$

O esquema da análise de covariância no delineamento de blocos ao acaso e as respectivas esperanças matemáticas dos produtos médios, aplicando-se essa metodologia, encontra-se na tabela 3. As componentes dos produtos médios foram obtidas separadamente pa ra cada local. De acordo com essa metodologia, a côv $p(x, y)$ é igual a $\frac{1}{4}$ da $\operatorname{Côv}_{A(x, y)}$ (FALCONER, 1964), onde a $\operatorname{Côv}_{A(x, y)}$ é a covariāncia genética aditiva entre os caracteres $x$ e $y$.

Os coeficientes de correlação genética e fenotípica entre os caracteres $x$ e $y$, foram estimados utilizando-se das metodo logias descritas por FALCONER (1964) e QUEIROZ (1969) da seguinte forma, para cada local:

$$
\tilde{r}_{A(x, y)}=\frac{C \hat{O} v_{A(x, y)}}{\sqrt{\sigma_{A_{x}}^{2} \cdot \hat{\sigma}_{A}^{2}}}
$$




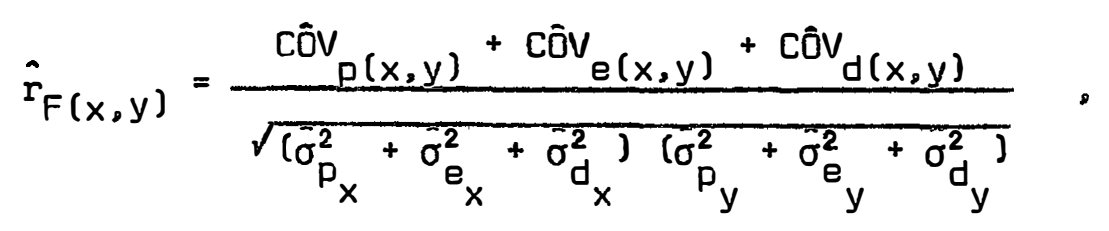

onde, $\tilde{r}_{A(x, y)}=$ coeficiente de correlação genética aditiva entre os caracteres $x$ e $y$, ao nível de indivíduos:

$\dot{r}_{F(x, y)}=$ coeficiente de correlação fenotípica entre bulbos para os caracteres $x$ e $y$.

Os demais termos já foram definidos anteriormente.

0 desvio padrão do coeficiente de correlação genéti-

ca aditiva foi calculado segundo a fórmula aproximada citada por FAL CONER (1964) e modificada por QUEIROZ (1969), como segue:

$$
\hat{\sigma}_{\left(\hat{r}_{A(x, y)}\right)} \cong \frac{4\left(1-\hat{r}_{A(x, y)}^{2}\right)}{\sqrt{T \cdot \hat{h}_{x} \cdot \bar{h}_{y}}},
$$

onde, $\hat{r}_{A(x, y)}$ = estimativa do coeficiente de correlação genética aditiva entre os caracteres $x$ e $y$ :

$h_{x}$ e $h_{y}=$ raizes quadradas das estimativas dos coeficientes de herdabilidade dos caracteres $x$ e $y$, respectivamente: $T=$ número total de bulbos analisados. 
32 .

\section{RESULTADOS}

\section{1 - Caracteres avaliados ao nivel de parcelas}

As produções médias por área de cebola, em kg por 2 $\mathrm{m}^{2}$ de parcela, relativas a 54 progênies de meios irmãos da população $C_{5}$ Baia Periforme Precoce $\times$ Red Creole, encontram-se na figura 1 como distribuições de frequiências. De um modo geral as produções das progênies de meios irmãos foram, consistentemente, maiores em Piracicaba que em Anhembi. A testemunha parental cultivar Red Creole apresentou as produções médias de $2,58 \mathrm{~kg}$ e $0,86 \mathrm{~kg}$ de bulbos co merciais por $2 \mathrm{~m}^{2}$. respectivamente para os locais Piracicaba e Anhem bi. A testemunha parental cultivar Composto Baia SMP-V produziu 4,37 $\mathrm{kg}$ e $1,36 \mathrm{~kg}$ por $2 \mathrm{~m}^{2}$ respectivamente para os mesmos locais. As pro gênies tiveram maiores produções médias por área que a testemunha cultivar Red Creole em ambos os locais. Com relação à testemunha cul 
tivar Composto Baia SMP-V, as progênies tiveram maior produção média por área em Anhembi. O coeficiente de correlação entre as prodú ções médias por área das progênies $(\bar{r}=0,1212 ; \mathrm{g} \circ 1 .=52)$ foi não significativo para os dois locais, indicação de não ocorrer associa ção entre as produções médias por ärea. Houve diferenças significativas entre as progênies para o caráter produção por área, considerando-se cada local em particular, como pode ser observado na tabela 4. Os coeficientes de variação foram de 18,56 e $29,09 \%$ respectivamente para Piracicaba e Anhembi. A precisão experimental dos presentes ensaios pode ser considerada satisfatória.

As distribuições de freqưências para a sobrevivência média pós-transplante das progênies de meios irmãos da população $C_{5}$ Baia $x$ Red Creole encontram-se na figura 2. Observa-se que a sobrevivência média em Piracicaba foi maior que em Anhembi, Para uma população ideal de 40 plantas por $2 \mathrm{~m}^{2}$, isto é. uma população de 200.000 plantas por ha, as sobrevivências médias foram de 39,12 e 34.91 plantas por $2 \mathrm{~m}^{2}$, respectivamente para Piracicaba e Anhembi. As testemunhas apresentaram maior sobrevivência que as progênies em Piracicaba. Em Anhembi a testemunha cultivar Composto Baia SMP-V apresentou menor sobrevivência que a média das progênies. As progênies de meios irmãos não diferiram significativamente entre si para o caráter sobrevivência em cada local, como pode ser observado na tabela 4. A precisão experimental foi alta, como demonstram os coeficientes de variação, de 1,48\% para Piracicaba, e 9,20\% para Anhem bi。 
Convém ressaltar que a inexistência de diferenças de sobrevivência para cada local e a obtenção de uma população quase ideal de plantas, ao nível de parcelas, favorecem as estimativas de parâmetros genéticos do presente trabalho, visto não terem sido fei tas correções para sobrevivência.

Na figura 3 observam-se as distribuições de freqüências para o nümero médio de plantas improdutivas por $2 \mathrm{~m}^{2}$. A ocorrên cia de plantas improdutivas em Piracicaba foi baixa em relação a Anhembi. Mesmo assim, em ambos os locais a incidência pode ser consí derada baixa. A testemunha cultivar Red Creole apresentou uma maior incidência de plantas improdutivas que a cultivar Composto Baia e as progênies de meios irmãos, em ambos os locais. As duas testemunhas apresentaram maior número de plantas improdutivas que as progênies, no experimento de Anhembi. As progênies de meios irmãos diferiram significativamente entre si para esse caráter, em cada local, como se observa na tabela 4. Os coeficientes de variação foram altos em decorrência de haver diferenças genéticas e ambientais mar cantes associadas a médias relativamente baixas. A precisão do expe rimento não pode ser considerada satisfatória para nenhum dos dois locais.

O caráter número médio de bulbos comerciais está apresentado na forma de distribuições de freqüências, na figura 4. Em Piracicaba o nümero de bulbos comerciais foi maior, em média. que para Anhembi. A testemunha cultivar Composto Baia apresentou-se 
com médias superiores à cultivar Red Creole para ambos os locais.As progênies de meios irmãos apresentaram em Anhembi uma média superior a ambas as testemunhas para o caráter número de bulbos comerciais. Nas condições experimentais de Anhembi, observou-se também uma amplitude elevada para esse caráter, variando de 18 a 40 bulbos comer ciais por $2 \mathrm{~m}^{2}$. 0 mesmo não ocorreu em Piracicaba. As progênies ava liadas não diferiram significativamente entre si, para cada local. Os resultados das análises de variância encontram-se na tabela 4 . A precisão experimental pode ser considerada alta, em vista dos coefi cientes de variação serem de $2,31 \%$ para Piracicaba e $13,42 \%$ para Anhembi。

\section{2 - Caracteres avaliados ao nível de individuos}

As distribuições de frequiências do caráter peso médio do bulbo "per se" das progênies de meios irmãos da população $C_{5}$ Baia x Red Creole ẽ apresentada na figura 5. 0 peso médio de bulbo para Piracicaba foi superior ao de Anhembi. A amplitude do peso médio de bulbo das progênies de meios irmãos ensaiadas em Anhembi foi de 45 a 105 g, com a média de 75,3 g. Para Piracicaba -a amplitude foi de 65 a $135 \mathrm{~g}$ 。 com a média de $98,5 \mathrm{~g}$. De modo geral, a testemunha cultivar Composto Baia apresentou peso individual em torno de $48 \%$ superior à testemunha cultivar Red Creole, em ambos os locais. As progênies de meios irmãos diferiram significativamente entre si para o caráter peso individual de bulbo, para cada local, como pode 
ser verificado na tabela 5 de análises de variância. Os coeficientes de variação relativos ao erro de parcela e a dentro de parcela, variaram de 34,95 a 60,35\% para os locais em estudo. A precisão experimental não foi satisfatöria para os dois locais estudados.

As progênies diferiram entre si significativamente ao nível de $1 \%$ em Piracicaba e ao de $5 \%$ em Anhembi para o caráter diâmetro de bulbo, como pode ser observado na tabela 6. Os coeficientes de variação relativos tanto a erro de parcela como a dentro de parcela, variaram de 13,71 a $26,57 \%$. A precisão experimental pode ser considerada satisfatória para os dois locais. As progênies ensaiadas em Anhembi tiveram um diâmetro em média menor que as ensaiadas em Piracicaba, porém foram superiores às duas testemunhas. Em Piracicaba as progênies e as testemunhas tiveram aproximadamente o mesmo diàmetro mëdio.

o caráter índice de formato foi definido como a rela ção altura sobre diâmetro de bulbo. Coms pode ser observado na tabe la 7, as progênies diferiram entre si significativamente para cada local. Isso demonstra que há variação para o formato de bulbo entre as progênies ensaiadas nas duas condições ambientais. A precisão experimental pode ser considerada satisfatória, visto os coeficientes de variação terem sido de 15,32 a 25,12\%. Pelas médias das progênies e testemunhas pode-se dizer que a testemunha cultivar Red Creole foi a de formato mais chato. As progênies expressaram o formato redondo para os dois locais, em média. 
Na figura 6 podem-se observar as distribuições de fre quiências para os teores médios de sólidos solúveis, em graus brix por bulbo, para as 54 progênies de meios irmãos da população estuda da. As progênies apresentaram para esse caráter aproximadamente a mesma amplitude de variação e a mesma média para os dois locais. A testemunha cultivar Red Creole foi consistentemente superior à outra testemunha parental e às progênies, para ambos os locais. A cul tivar Composto Baia foi inferior às progênies nos dois locais. Na tabela 8 encontram-se as análises de variância para o caráter teor de sólidos solúveis. Observa-se que as progênies diferiram significativamente entre si para esse caráter, em cada local. A precisão dos experimentos pode ser considerada satisfatória, como demonstram os coeficientes de variação do erro de parcela e dentro de parcela. que oscilaram de 14,57 a $22,06 \%$

\section{3 - Coeficientes de herdabilidade para caracteres de bulbo e planta de cebola}

\subsection{1 - Caracteres avaliados ao nivel de parcelas}

Na tabela 9 encontram-se as estimativas dos componen tes da variância de caracteres ao nível de parcelas. Através dos com ponentes da variância foram estimados os coeficientes de herdabilidade entre médias de progênies, o progresso esperado na seleção e o coeficiente de variação genética, que podem ser observados na tabela 10 . 
0 coeficiente de herdabilidade, para produção de bul bo por área, considerando-se seleção entre médias de progênies, variou conforme o local. Nas condições experimentais de Piracicaba, o coeficiente de herdabilidade para produção de bulbo por área foi de $67,63 \%$, enquanto que para Anhembi foi menor, isto $\bar{e}^{-}$de $41,64 \%$. Estimativas do progresso genético esperado, em porcentagem, com base em seleção entre progênies de meios irmãos, foram relativamente altas para produção por área, sendo que o valor estimado para Piracicaba foi maior que para Anhembi. Para o coeficiente de variação genética, os valores situaram-se em torno de 12 a $13 \%$, para os dois locais. Na população $C_{5}$ Baia Periforme $\times$ Red Creole, observa-se que, para o caráter produção por ärea as estimativas do coeficiente de herdabilidade são altas, o mesmo ocorrendo com os coeficientes de variação genética. Deve-se ressaltar que a precisão experimental dos dois ensaios pode ser considerada satisfatória para a obtenção de es timativas de componentes, como demonstram seus coeficientes de variação de 18,56 e 29,09\%, para Piracicaba e Anhembi respectivamente.

Para o caráter sobrevivência, a população mostrou bậ xos coeficientes de herdabilidade para ambos os locais, sendo que pa ra as condições de Anhembi o valor foi o dobro que para Piracicaba. - qual foi de 4,35\%. Os ganhos genéticos esperados, bem como os coe ficientes de variação genética para esse caráter, também foram pequenos. As estimativas dos componentes foram obtidas de ensaios bas tante precisos, como demonstram os coeficientes de variação de 1,48 e $9,20 \%$ respectivamente. 
Para o caráter número de plantas improdutivas ocorreu um comportamento inverso ao dos outros caracteres. Os coeficien tes de herdabilidade foram altos para ambos os locais, porém maior para Anhembi $(52,39 \%)$. Quanto ao progresso genëtico esperado, obser va-se que para as condições de Anhembi as estimativas foram o dobro das obtidas nas condiçōes de Piracicaba. Por ser um caráter indesejāvel, as estimativas do progresso genético dão valores negativos. indicando uma diminuição do nümero de plantas improdutivas na próxí ma geração. Os coeficientes de variação genética tiveram comportamento semelhante, sendo de 17,75 e $24,46 \%$ para Piracicaba e Anhembi respectivamente. Deve-se frisar que as estimativas dos componentes foram obtidas de ensaios. com precisão experimental não satisfatōrias em vista de seus elevados coeficientes de variação, respectivạ mente de $40,88 \%$ para Piracicaba e $46,63 \%$ para Anhembi.

O caräter número de bulbos comerciais apresentou um coeficiente de herdabilidade de 18,86 e $23,88 \%$, respectivamente para Anhembi e para Piracicaba. O progresso genético esperado para Pí racicaba foi o dobro do esperado para Anhembi. Os coeficientes de variação genética foram baixos para ambos os locais 12,64 e $2,91 \%$, respectivamente para Piracicaba e Anhembi)。A precisão experimental também pode ser considerada satisfatória para a obtenção de estimativas de componentes de variância, visto os coeficientes de variação de 2,31 e 13,42\%, respectivamente para Piracicaba e Anhembi. 


\subsection{2 - Caracteres avaliados ao nivel de individuos}

As estimativas dos componentes de variância para os caracteres ao nf́vel de indivíduos, encontram-se na tabela 11. Atra-

vés desses componentes foram estimados os coeficientes de herdabili dade no sentido restrito, o progresso genético esperado considerando-se dois esquemas de seleção massal, e os coeficientes de variação genética. Estas estimativas estão apresentadas na tabela 12.

Para peso de bulbo, os coeficientes de herdabilidade no sentido restrito foram de 39,09 e 12,01\% respectivamente para Pi $_{\text {. }}$ racicaba e Anhembi. A estimativa do progresso genético esperado,con siderando-se seleção massal estratificada, e cada bloco como um estrato, foi maior em Piracicaba $(21,07 \%)$ que em Anhembi $(6,63 \%)$. Igual comportamento teve a mesma estimativa de progresso esperado, considerando-se o esquema de seleção massal estratificada, tendo ca da parcela como um estrato. O coeficiente de variação genética foi duas vezes maior em Piracicaba $(12,03 \%)$ que em Anhembi $(6,83 \%)$. Esses valores foram calculados com estimativas de componentes da variância obtidos de dois ensaios que não tiveram precisão experimental satisfatória, como mostram seus elevados coeficientes de variação, oscilando entre 34,95 e $60,35 \%$.

Considerando-se o caráter diâmetro de bulbo, pode-se observar que as estimativas de coeficientes de herdabilidade e do progresso genético esperado, para os dois esquemas seletivos em Piracicaba, são aproximadamente o dobro dos valores estimados para A- 
nhembi. Os coeficientes de variação genética podem ser considerados baixos, sendo que Piracicaba apresenta valor pouco mais elevado que Anhembi, que são de 4,15 e 3,07\%, respectivamente. A precisão experimental dos dois ensaios pode ser considerada satisfatória para a obtenção de componentes de variância, para ambos os locais.

Para o indice de formato, pode-se observar que as es timativas de herdabilidade são muito elevadas; uma delas inclusive, ultrapassa seu valor de definição, ou seja, o valor l. Possivelmente problemas de amostragem insatisfatória estão relacionados a esse valor inesperado. As demais estimativas da tabela apresentam valores da mesma magnitude para os dois locais. 0 progresso genético es perado pode ser considerado elevado, porém deve-se ressaltar um pos sível erro associado a amostragem insuficiente. A precisão experimental dos ensaios pode ser considerada satisfatória, como demonstram seus coeficientes de variação entre 15,32 e $25,12 \%$.

Coeficientes de herdabilidade elevados também foram éstimados para o teor de sólidos solüveis, porém Piracicaba apresen ta-se com um coeficiente mais elevado $(40,73 \%)$. Os progressos esperados com a seleção foram de 9,41 e $7,42 \%$ respectivamente para Pira cicaba e Anhembi, considerando-se seleção massal estratificada, sen do cada bloco um estrato. Para a seleção massal estratificada, onde cada parcela é um estrato, os ganhos foram menores. Os coeficientes de variação genética tiveram valores de mesma magnitude para os dois locais. As estimativas de componentes foram obtidas de dois ensaios com precisão experimẹtal satisfatōria, como demonstram seus coefi- 
cientes de variação.

Deve-se frisar que todas as estimativas tiveram valo res mais elevados para Piracicaba que para Anhembi. Observa-se tambẻm que, para todos os caracteres, os progressos genéticos esperados considerando-se o esquema de seleção massal estratificada, sendo cada bloco um estrato, foram aproximadamente $30 \%$ superiores ao outro esquema seletivo, o de seleção massal estratificada sendo cada parcela um estrato, considerando-se a mesma intensidade de seleção para os dois estratos.

\section{4 - Correlações entre caracteres de bulbo e planta de cebola}

\section{4 .1 - Caracteres avaliados ao nivel de parcelas}

As análises de covariância para os pares de caracteres avaliados ao nível de parcelas encontram-se na tabela 13. Os produtos médios possibilitaram a obtenção das estimativas dos componentes dos produtos médios para cada associação de caracteres, estimativas essas que se encontram na tabela 14. Observa-se que essas estimativas variaram com os locais, porëm com concordância de sinal para ambos os locais, com raras exceções.

As estimativas das variâncias fenotípicas dos caracteres e das covariâncias fenotípicas para os pares de caracteres avaliados ao nível de parcelas encontram-se na tabela 15. Na diagonal encontram-se as estimativas das variâncias e acima da diagonal encontram-se as covariâncias estimadas. Essa disposição facilita a 
comparação das estimativas para os dois locais considerados. Observa-se que as covariâncias são concordantes em sinal, sendo que os valores variaram conforme o local considerado. As estimativas foram em geral maiores para Anhembi que para Piracicaba.

A partir das estimativas das variâncias e covariâncias fenotípicas, foram obtidos os coeficientes de correlação fenotí pica entre médias de caracteres. Estas estimativas encontram-se na tabela 16, com as respectivas significâncias; observa-se que os valores variaram conforme o local. De modo geral, as correlações foram concordantes para significância em ambos os locais, exceto para as correlações entre produção por ärea e sobrevivêncie e entre produção por área e número de bulbos comerciais: Os maiores valores de correlações foram obtidos para os pares de caracteres sobrevivência e número de bulbos comerciais, e nümero de bulbos comerciais e núme ro de plantas improdutivas.

As estimativas de $1 / 4$ das variâncias genéticas aditi vas dos caracteres e de $1 / 4$ das covariâncias genéticas aditivas para os pares de caracteres ao nível de parcelas, estão na tabela 17. De maneira geral, as covariâncias diferiram para os dois locais; en tretanto, foram concordantes em sinal, com exceção dos pares de caracteres produção por área e número de plantas improdutivas, sobrevivência e número de bulbos comerciais e sobrevivência e número de plantas improdutivas.

Na tabela 18 podem-se observar as estimativas dos coe ficientes de correlação genética aditiva, para os caracteres avalia 
dos ao nível de parcelas. Há uma concordância em sinal, com exceção dos pares de caracteres já citados para as covariâncias. Os valores também variaram conforme o local.

As correlações fenotípicas e genéticas, com raras ex ceções, mostram concordância de sinais.

\subsection{2 - Caracteres avaliados ao nivel de individuos}

Na tabela 19 são encontradas as análises de covariân cias para os pares de caracteres, ao nível de indivíduos. Através das análises de covariância, foram obtidos os componentes dos produ tos médios para os pares de caracteres, para cada local, como são ob servados na tabela 20 .

Observa-se que os valores das estimativas dos componentes das covariâncias variaram com o local e que não há concordân cia de sinal ou magnitude para a mesma estimativa, em ambos os locais, de maneira geral.

Na tabela 21 encontram-se as estimativas das variâncias fenotípicas dos caracteres e das covariâncias fenotípicas para os pares dos caracteres avaliados ao nível de indivíduos. Na diagonal observam-se as variâncias fenotípicas e, acima da diagonal, as covariâncias. As estimativas das covariâncias fforam diferentes para cada local, porém há concordância de sinal para os dois locais pa ra quase todos os pares de caracteres: as exceções são entre diâmetro de bulbo e índice de formato, e entre índice de formato e teor de sólidos solúveis. 
Através das variâncias e covariâncias fenotípicas foram estimados os coeficientes de correlação fenotípica para os caracteres avaliados a nível de indivíduos, que são encontrados na tạ bela 22. Pode-se notar que os valores variaram para o local conside rado. Há concordância de sinal para as mesmas estimativas, para ambos os locais, com exceção das correlações entre diâmetro de bulbo e indice de formato, e entre indice de formato e teor de sólidos so lúveis. Deve-se ressaltar que alguns valores devem ser tomados com reservas, devido ao fato de terem sido calculados a partir de compo nentes de produtos médios e quadrados médios de ensaios onde, possi velmente, as amostragens foram não satisfatórias, ou com baixa precisão experimental para a obtenção de estimativas de componentes.

O coeficiente de correlação entre peso de bulbo e ín dice de formato ultrapassou o intervalo de valores considerados, por definição, para coeficientes de correlação $\left(-1 \leq r_{F} \leq+1\right)$ devido aos problemas citados acima. Também os outros coeficientes de correlação calculados com o caráter índice de formato devem ser tomados com cautela.

Na tabela 23 encontram-se as estimativas das variâncias genéticas aditivas dos caracteres e das covariâncias genéticas aditivas dos pares de caracteres avaliados ao nível de indivíduos. Os valores variaram com o local considerado, para a mesma estimativa. Não hã em geral, concordância de sinal para ambos os locais. Os valores para Piracicaba foram consistentemente maiores que para Anhembi, com algumas exceções. 
Através das variâncias e covariâncias genéticas aditivas foram estimados os coeficientes de correlação genética aditiva entre os caracteres, a nível de indivíduos, que se encontram na tabela 24 .

Os valores das correlações genéticas aditivas variaram conforme o local considerado, porém foram concordantes em sinal, com duas exceções: as correlações entre peso e diâmetro de bul bo e entre diâmetro e teor de sólidos solúveis. Os valores das correlações entre peso e teor de sólidos solúveis e entre diâmetro e indice de formato foram consistentemente elevados para ambos rs 10cais.

0 maior valor de correlação genética ocorreu entre peso e diâmetro de bulbo, para o local Piracicaba. Já todas as correlações envolvendo Indice de formato, para o local Piracicaba, devem ser tomadas com reservas. Foram calculadas com estimativas possivelmente erradas de componentes, devido a amostragem não satisfatória, ou a erro experimental muito elevado. Devido ao mesmo erro,a correlação entre peso e índice de formato, para Piracicaba, está fo. ra do intervalo de valores considerados, por definição, para coeficientes de correlação genética $\left(-1 \leq \mathrm{r}_{\mathrm{A}} \leq+1\right)$ 。

Houve também concordância entre os coeficientes de correlação fenotípica e genética entre peso e teor de sólidos solúveis, em sinal e magnitude, para ambos os locais. 
5.5 - Gradiente do teor de sólidos solüveis do bulbo de cebola

0 bulbo de cebola apresenta teores variáveis de sóli dos solúveis, como pode ser verificado na figura 7. Há um gradiente de teores de sólidos solúveis da parte externa para a interna do bul bo, e da região apical para a basal. De modo geral as camadas inter nas, bem como as basais, apresentam de 24 a $45 \%$ mais de sólidos solúveis que as camadas apicais e as externas, respectivamente. o teor de sólidos solúveis total do bulbo deu um valor médio de $10,24 \%$. Apesar de as camadas externas apresentaram valores menores que os valores totais do bulbo, ambos os valores são altamente correlacionados, $r=0,5097 * *\left(g_{0} l_{0}=78\right)$ 。

A utilização das camadas externas para amostrar o bu bo inteiro é feita nos métodos não destrutivos, para seleção de bul bos com teores de sólidos solúveis elevados. 
48 。

\section{DISCUSSÃO}

6.1 - Coeficiente de herdabilidade para caracteres avaliados ao nivel de parcelas

A cebola é uma espécie alógama, cujo produto comercial, botanicamente denominado bulbo, antecede a fase de florescimento. No melhoramento da cebola, vêm sendo utilizados métodos simples, como a seleção massal, com relativo sucesso (JONES e MANN, 1963: DIAS e COSTA, 1967). Além do mais, os progressos são elevados porque a seleção é feita antes do florescimento, para todos os caracteres da planta e do produto comercial.

A experiência em outras espécies alógamas tem mostra do ser promissora a seleção feita com base em progênies de meios ir mãos (PATERNIANI, 1968; CARMO, 1969; DIAS et alii, 1971 e outros). No caso da cebola são inexistentes os trabalhos onde se utilizam da seleção entre progênies de meios irmãos. 
0 presente trabalho objetivou estimar alguns parâmetros, como o coeficiente de herdabilidade, a correlação entre carac teres, com base na avaliação de progênies de meios irmãos, da população $C_{5}$ Baia $\times$ Red Creole, e suas implicações no melhoramento de cebola.

Para que o melhoramento de população seja eficiente, é fundamental a existência de variabilidade genética, associada com produtividade e outras qualidades.

A produção de cebola, avaliada no presente trabalho em $\mathrm{kg}$ de bulbos comerciais por $2 \mathrm{~m}^{2}$, considerando-se uma população ideal de 200.000 plantas por hectare, é o caráter de maior importân cia para o produtor, bem como para o melhorista. As produções das progênies de meios irmãos variaram, conforme o local, entre 2,5 a 30 ton por ha. Deve-se frisar que a cultura da cebola foi feita na época normal, isto é, feita através de mudas, com semeaduras emmaio, e a colheita em outubro. Trata-se da época de cultivo mais favorável para a cebola, pois coincide com o período de menor pluviosidade e de temperaturas amenas (DIAS e COSTA, 1970)。

As menores produções para Anhembi relacionam-se, pos sivelmente, a menor fertilidade e à falta de manutenção de umidade adequada, devido ao tipo arenoso de solo. SINGH e ALDENFER (1966)ve rificaram que a cebola é sensivel ao déficit de água em qualquer es tágio do seu desenvolvimento. Também CONCEIÇÃO (1971), relatou que o nível da umidade do solo afetou a produção por área, o número de bulbos comerciais e o peso médio por bulbo. Mesmo assim, o coefici- 
ente de herdabilidade para produção por área considerando-se seleção entre médias de progênies, foi alto para os dois locais conside rados, dando a idéia de que o material ofensce ampla possibilidade de progresso, selecionando-se as progênies em condições tanto de Pi. racicaba como de Anhembi. Deve-se atentar ao fato de que os coefici entes de herdabilidade, como aqui estimados são dependentes do núme ro de repetições. Se for aumentado o número de repetições, a estima tiva da herdabilidade para produção por área diminuirá. As estimati vas de progresso genético mostram e confirmam a viabilidade de uma seleção eficiente, com base em progênies de meios irmãos, em ambos os locais.

Observando-se a figura 1 , verifica-se que a população $C_{5}$ Baia $\times$ Red Creole é promissora. A amplitude das produções mé dias das progênies por área permite uma visualização, do ponto de vista prático, da variabilidade que a população $C_{5}$ Baia $\times$ Red Creole apresenta. Algumas das progênies chegam a ser $37 \%$ mais produtivas que a testemunha de maior produção para Piracicaba. Já para Anhembi algumas progênies chegam a ser $157 \%$ mais produtivas.

o coeficiente de variação genética estima o grau de variabilidade genética presente na população. No presente trabalho, os coeficientes de variação genética foram quase da mesma magnitude. para os dois locais. Os valores do coeficiente de variação genética vêm reforçar a idéia de possibilidade de seleção para as condições ambientais estudadas. 
Não houve, também, correlação entre as produções mēdias por área das progênies avaliadas em Piracicaba e das mesmas pro gênies avaliadas em Anhembi. A ausência de correlação mostra não hạ ver associação entre as produções; as progênies com as maiores produções em Piracicaba não foram as de maiores produções em Anhembi.

0 comportamento diferencial das progênies demonstra a importāncia de o melhoramento ser feito para determinada condição am biental.

A precisão experimental pode ser considerada satisfa tória, como demonstram seus coeficientes de variação. Os valores de coeficiente de variação obtidos são maiores que o obtido por YAKOY $\underline{A}$ MA (1976), para a mesma época de cultivo.

O cultivo de cebola pelo processo de mudas é constituído de duas fases: a semeadura em canteiro, e posterior transplan te definitivo para o campo. Considerando-se que o transplante das progênies para os dois locais deu-se em época favorável de fotoperíodo e temperatura, a sobrevivência resultou alta para os dois en saios. A média da sobrevivência das progênies foi respectivamente de 97,80 e $87,28 \%$ em relação ao número ideal de 40 plantas por $2 \mathrm{~m}^{2}$,res pectivamente para Piracicaba e Anhembi. A menor sobrevivência para Anhembi deve-se prender ao fato de ai haver solos arenosos, de baixa fertilidade, e de haver dificuldade de retenção de água no solo. Existem progênies que suplantam as testemunhas quanto à maior sobre vivência nas condições de Anhembi. 
Os pequenos valores do coeficiente de herdabilidade, de $4,35 \%$ para Piracicaba e de $10,35 \%$ para Anhembi, mostram que não se terá progresso com a seleção entre progênies para sobrevivência, considerando-se a ëpoca dos ensaios. Deve-se ressaltar que todas as estimativas foram feitas com progênies que não diferiram entre si para sobrevivência. Assim pode-se considerar que não há praticamente diferenças devido a causas genéticas, mas sim devido a fatores am bientais. Portanto, a seleção das progênies para maior sobrevivência e na época considerada, praticamente não trará resultados, como tạ bém demonstram os pequenos valores de progressos genéticos esperados, para os dois locais.

A quase inexistência de variabilidade genética na po pulação para sobrevivência, considerando-se a época normal, é demons trada também pelos baixos coeficientes de variação genética obtidos, isto é, 0,16 e 1,56\% respectivamente para Piracicaba e Anhembi. 0 aumento da sobrevivência na presente população deve, então, envolver outros aspectos, como tamanho e vigor das mudas, que são relacionados com a densidade de semeadura no viveiro (KNOTT, 1951), e outros fatores ambientais, já que o pegamento dás mudas no campo é dependente do tamanho das mudas e da disponibilidade de água (JONES e MANN, 1963). A precisão experimental obtida para a sobrevivência, foi semelhante à obtida por YOKOYAMA (1976), para a mesma época de cultivo。

0 número de plantas improdutivas é um caráter de ocorrência indesejável e, de certa maneira, afeta a produtividade.As 
plantas improdutivas são plantas que na época da colheita não forma ram bulbos comerciais, por razões de natureza genética e não genéti ca.

A incidência de plantas improdutivas é baixa, como pode ser observada na figura 3. A baixa incidência se prende à épo ca favorável na qual os ensaios foram realizados. A amplitude dos valores médios das progênies para o caráter foi estreita para Piracicaba, porém, o mesmo não ocorreu para Anhembi. A alta incidência de plantas improdutivas para Anhembi, prende-se às condições ambien tais adversas. 0 solo arenoso pode ser crítico em aumentar o nümero de plantas improdutivas, por falta de umidade do solo.

Mesmo assim, as progênies diferiram significativamen te entre si, para os dois locais, para o número de plantas improdutivas. As causas genéticas nas diferenças entre as progênies são al tas, em relação às causas genéticas e ambientais da variação, como demonstram os altos coeficientes de herdabilidade 139,92 e $52,39 \%$ respectivamente para Piracicaba e Anhembi). As possibilidades de se leção para diminuir o número de plantas improdutivas são evidentes, como demonstram os progressos genéticos esperados com a seleção entre progênies $(-18,07 \%$ para Piracicaba e $-31,16 \%$ para Anhembi). Nota-se também que, para as condições de Anhembi, os ganhos serão qua se 2 vezes maiores que os de Piracicaba.

A existência de variabilidade genética é confirmada pelos valores do coeficiente de variação genética, para os dois 10cais (17,75\% para Piracicaba e $24,46 \%$ para Anhembi). As diferenças 
existentes nos valores de herdabilidade, progresso genético esperado e coeficiente de variação genética, podem ser devidos a interações do genótipo com o ambiente, não calculadas no presente trabaIho.

Deve-se frisar que os componentes da variāncia foram obtidos de ensaios com elevados coeficientes de variação, segundo o critério adotado por PIMENTEL GOMES (1973). Elevados coeficientes de variação para número de plantas improdutivas são conhecidos na lite ratura (ZIMMERMANN, 1973; YOKOYAMA, 1976)。Segundo RATERNIANI(1968) há várias causas que contribuem para o aumento do coeficiente de va riação experimental. As causas podem ser devidas a falhas na condução dos ensaios ou a fatores inerentes ao material e métodos utilizados. A existência de variabilidade genética dentro das progênies de meios irmãos e a interação genótipo por ambiente são dois desses fatores.

A produtividade da cebola pode ser medida em termos, ou de peso de bulbos por área, ou de número de bulbos comerciais por ärea. No melhoramento há maior interesse em se avaliar o peso de bul bos por área, devido ao ponto de vista comercial.

0 caráter número de bulbos comerciais serve para expressar, de certa maneira, o potencial de produção da progênie, vis to que representa o nümero de bulbos comerciais remanescentes para um total de 40 plantas por $2 \mathrm{~m}^{2}$. No presente trabalho não se verifi caram diferenças significativas entre as progênies para ambos os 10 cais considerados. Possivelmente não se conseguiram detectar peque- 
nas diferenças devido ao nümero de progênies avaliadas,já que o coe ficiente de variação genética mostra a existência de pequena variação na população (2,64\% para Piracicaba e 2,91\% para Anhembi).

0 coeficiente de herdabilidade confirma a possibilidade de progresso na seleção entre progênies, 23,88 e 18,86\% respec tivamente para Piracicaba e Anhembi, porém, como demonstram os valo res dos progressos genétịcoṣ esperados, os ganhos não serão elevados.

Os pequenos valores do coeficiente de variação genética, por outro lado, mostram que as possibilidades de progressos por várias gerações de seleção são limitadas, devido à pequena variabilidade existente na população. Este fato e compreensível visto que, ao se atingirem 40 bulbos comerciais por $2 \mathrm{~m}^{2}$, as possibilidades de seleção serão nulas, pois se atingiu o máximo para o caráter. Interessante è se observar que, para Piracicaba, os ganhos esperados são o dobro que para Anhembi, fazendo-se seleção entre progênies. Entretanto, na figura 4 pode-se observar que há em Anhembi progênies com alto número de bulbos comerciais.

Todavia, o número de bulbos comerciais deve ser considerado juntamente com a produção por $2 \mathrm{~m}^{2}$. A situação ideal sería 40 plantas resultando em bulbos comerciais com peso unitário ideal em torno de 100 gramas.

0 método tradicional de seleção para produtividade é selecionar-se o bulbo "per se". Na seleção por progênies há necessi dade de se selecionar o nümero de bulbos comerciais e a produção por 
àrea.

Deve-se observar que através da seleção de progênies de meios irmãos, há possibilidade de progresso para os caracteres produção por área, número de bulbos comerciais e diminuição do núme ro de plantas improdutivas. Praticamente a sobrevivência é um caráter que não terá progressos na seleção. Deve-se considerar que as mudas transplantadas foram escolhidas para vigor e tamanho ideal,co mo na prática dos cebolicultores. As diferenças entre as progênies para sobrevivência são, então, de natureza ambiental.

São marcantes os maiores progressos esperados para produção por área e número de bulbos comerciais, para a seleção entre progênies em Piracicaba. Maiores progressos também são esperados para diminuição do número de plantas improdutivas, na seleção en tre progênies em Anhembi. Este comportamento vem também consubstanciar a idéia de que o melhoramento de um dado caráter, feito nas con dições ambientais que possibilitam sua máxima expressão, tem maiores possibilidades de êxito.

\section{2 - Coeficiente de herdabilidade para caracteres avaliados ao nivel de individuos}

A existência de variabilidade genética é condição bá sica para a eficiência dos métodos de melhoramento de população. De modo geral, a grande variabilidade genética em plantas, está forte mente relacionada com o sistema reprodutivo da espécie (STEBBINS, 1957). A cebola é uma espécie hortícola alógama (JONNES e MANN, I963)。 
porém com pequena taxa de autofecundação natural em campo. Segundo VAN DER MEER e VAN BENNEKON (1968), há 9\% de autofecundação em condições ambientais da Holanda. Para as nossas condições não foram ainda estabelecidas.

Os métodos de melhoramento que se têm mostrado eficientes para as espécies alógamas são: seleção massal, retrocruzamento, hibridação de cultivares ou linhagens para utilizar-se do vi gor de híbrido, seleção recorrente, obtenção de variedade sintética, além de seleção entre e dentro de progênies de meios irmãos (LONNQUIST, 1965; PATERNIANI, 1968; ALLARD, 1971).

Na cebola têm sido utilizados os métodos de seleção massal e hibridação entre cultivares ou linhagens, visando à utilização de vigor de híbrido em $F_{1}$ (JONNES e MANN, 1963; DIAS e COSTA, 1967; BREWBAKER, 1969; ALLARD, 1971 e PATERNIANI, 1974)。

0 melhoramento de uma população de cebola pode ser feito objetivando o aumento da produção e da qualidade dos bulbos, para utilização direta como cultivar, ou então para obtenção de linhagens para a produção de híbridos.

0 melhoramento de uma população por seleção depende da magnitude da variância genética aditiva que está presente (LONQUIST, 1965)。Considerando-se o peso individual de bulbo, pode-se afirmar que há variância genética aditiva na população, quando se consideram isoladamente os dois locais. A diferença entre os valores pode ser explicada pela possível existência de interação genóti po por ambiente, cujo componente não foi isolado por não ter sido 
58.

feita a análise conjunta para os dois locais.

Há possibilidades de melhoramento da população para o peso do bulbo, utilizando-se mesmo de seleção massal, como demons tram os altos valores de coeficiente de herdabilidade do caráter con siderado, para cada local. Os valores de herdabilidade para peso de bulbo, estimados para Piracicaba $(39,09 \%)$ e para Anhembi $(12,01 \%)$. não concordaram com o valor estimado por NAKAMURA (1959), que foi de $0 \%$, e também com os estimados, para algumas populações da cultivar Yellow Sweet Spanish, por McCOLLUM (1966, 1968 e 1971). A herdabili dade para peso de bulbo estimada para Anhembi foi concordante em mag nitude com outras populações de cebola de dias longos, relatadas por McCOLLUM (1966). A estimativa da herdabilidade de peso de bulbo para Piracicaba foi superior à obtida em outras populações de cebola de dias longos, por McCOLLUM (1968, 1971)。

Vários efeitos ambientais influem no peso do bulbo e, consequentemente, na variância fenotípica total. CONCEIÇÃO (1971) re lata que o nível de umidade do solo afetou o peso médio do bulbo. 0 espaçamento utilizado, juntamente com a fertilidade do solo, que se relacionam à competição entre plantas, também influenciam o peso do bulbo, segundo JONES e MANN (1963).

A discrepância entre os valores estimados e os citados na literatura é explicada porque o coeficiente de herdabilidade é dependente da população, do ambiente considerado (HANSON, 1963) e também do processo utilizado para a sua estimativa (FALCONER, 1964). A diferença entre Piracicaba e Anhembi para o coeficiente de herda- 
bilidade pode ser explicado pela possível existência de interação ge nótipo por ambiente e por 'maior variação fenotípica existente em Anhembi. Deve-se considerar, também, que os coeficientes de variação para os experimentos foram muito altos, isto é, entre 34,95 e $60,35 \%$ segundo o critério adotado por PIMENTEL GOMES (1973). A falta de pre cisão experimental pode estar influindo na magnitude das estimativas de componentes de variância, que, por sua vez, estariam estiman do coeficientes de herdabilidade pouco precisos. A falta de precisão experimental é outra possível causa da discrepância entre os va lores obtidos e os citados na literatura.

As possibilidades de sucesso na seleção de peso de bulbo, na população $C_{5}$ Baia $\times$ Red Creole, para cada local considera do. são confirmadas pelos altos progressos genéticos esperados,con siderando-se seleção massal estratificada com estratos a nível de blocos ou de parcelas.

Os progressos genéticos esperados variaram com o local e com o tipo de estrato. Considerando-se cada bloco ou cada par cela como um estrato, Piracicaba apresentou valores de progresso es perado três vezes maiores, em média, que em Anhembi. As diferenças entre os progressos genéticos esperados com a seleção massal tendo cada bloco ou cada parcela como um estrato, entre os dois locais, de vem-se a diferentes estimativas de variância genética aditiva e tam bém a diferentes variâncias fenotípicas para cada local. As diferen ças entre as variâncias genéticas aditivas e entre as variâncias fe notípicas podem ser atribuídas a uma possível interação genótipo por 
60.

ambiente. Já as diferenças entre os dois esquemas seletivos, para um mesmo local, podem ser atribuídas a diferentes variâncias fenotí picas, para cada estrato considerado. E notória a diminuição em $30 \%$ no progresso genético esperado quando se considera a parcela como um estrato.

Os coeficientes de variação genética, respectivamente de 12,03 e $6,83 \%$ para Piracicaba e Anhembi, mostram também a existência de variabilidade genética para peso de bulbo, na população $C_{5}$ Baia $\times$ Red Creole para os dois locais. As diferenças entre os valores de coeficientes de variação genética estimados para Pira cicaba e Anhembi, devem ser atribuídas a uma possível interação genótipo por ambiente e também às médias diferentes para peso de bulbo, para cada local.

Para o diâmetro de bulbo, há também variância genéti ca aditiva na população $C_{5}$ Baia Periforme $\times$ Red Creole para cada lo cal considerado. Seus coeficientes de herdabilidade para o caräter em questão, respectivamente de $24,34 \%$ para Piracicaba e $12,59 \%$ para Anhembi, demonstram que há possibilidade de sucesso na seleção, mes mo utilizando-se de métodos simples como a seleção massal. Os coefí cientes de herdabilidade estimados para os dois locais concordam,em geral, com os valores estimados por McCOLLUM (1966, 1968 e 1971),pa ra dezessete populações de cebola de dias longos.

Vários efeitos ambientais podem estar influindo na va riação fenotípica total do diàmetro de bulbo, como a competição entre plantas, e o nivel de fertilidade do solo. Segundo JONES e MANN 
(1963), o tamanho do bulbo aumenta se houver espaçamentos amplos.

Os progressos genéticos esperados com a seleção massal estratificada, considerando-se o bloco ou a parcela como um estrato, confirmam a possibilidade de sucesso na seleção para o diâme tro de bulbo, nos dois locais considerados. Aqui também há diferenças para o progresso esperado, entre os dois esquemas de seleçãomas sal, sendo que a seleção massal considerando o bloco como um estrato é superior, nos dois locais, ao outro esquema seletivo.

As diferenças entre as estimativas de herdabilidade. entre o progresso genético esperado e entre os dois esquemas seleti vos, podem ser atribuídas às mesmas cáusas já citadas para peso do bulbo, isto é, possível interação genótipo por ambiente e diferentes variâncias fenotípicas obtidas.

Os coeficientes de variação genētica confirmam a exis tência de variabilidade na população para diâmetro de bulbo. Piraci caba e Anhembi apresentaram respectivamente 4,15 e 3,07\% de coefici ente de variação genética para diâmetro de bulbo, o que, de certa maneira, não pode ser considerado elevado. O sucesso da seleção para maior diâmetro será mínimo, modificando-se também o índice de for mato. Deve existir um limite a partir do qual a quantidade e a espessura das escamas do bulbo poderão limitar o diâmetro, consideran do-se ausência competitiva de plantas.

A precisão experimental pode ser considerada satisfa tória para a obtenção de estimativas de variância, como demonstram seus coeficientes de variação entre 13,71 a $26,57 \%$, nos dois ensaios. 
Para o carāter índice de formato, a população $C_{5}$ Baia $\times$ Red Creole apresentou variância genética aditiva de $4,04 \times 10^{-2} /$ /bulbo e $4,68 \times 10^{-2} /$ bulbo, respectivamente para os locais Piracica ba e Anhembi. 0 elevado coeficiente de herdabilidade para o índice de formato, no local Anhembi $(99,57 \%)$, indica que se pode prever su cesso na seleção para formato do bulbo mesmo utilizando-se de métodos simples como a seleção massal. A herdabilidade estimada para o local Anhembi discorda da relatada por NAKAMURA (1959) que foi de 32\%, e também das relatadas por McCOLLUM (1966), que variaram entre 33,58 e 67,80\%.Porém, algumas populações de cebola de dias longos estudadas por McCOLLUM (1968, 1971) apresentaram coeficientes de her dabilidade tão elevados como os obtidos para o local Anhembi.

Os progressos esperados com a seleção massal estrati ficada para Índice de formato estão entre 25,12 e $31,17 \%$, considerando-se diferentes estratos para os dois locais. Assim, confirma-se a facilidade de modificar por seleção o formato do bulbo para ambos os locais.

Deve-se ressaltar que estes valores referem-se a uma população com densidade ideal de 200.000 plantas por hectare. Para - caso de semeadura direta em que se coloca cinco vezes o número de plantas utilizado no presente trabalho, devem-se esperar menores ga nhos na seleção para formato, devido à intensa competição entre plạ tas. Segundo JONES e MANN (1963), se o espaçamento é reduzido os buI bos tornam-se usualmente mal formados e sem valor comercial. 
63.

As diferenças observadas entre as estimativas para os dois locais, podem ser atribuídas às mesmas causas citadas anteriormente para peso e diâmetro de bulbo.

Quanto aos dois esquemas seletivos considerados, observa-se que o progresso esperado com a seleção massal estratificada considerando cada bloco como um estrato, foi superior em 20 e 16\% à seleção massal estratificada considerando-se parcela como um estrato, respectivamente para Piracicaba e Anhembi. Esse resultado mos tra que a diminuição do estrato não resultará em aumento da eficiên cia da seleção, visto que se terá uma diminuição da variância genética aditiva disponível, de maneira não proporcional à diminuição da variância fenotípica dentro do estrato.

A maior eficiência esperada da seleção massal estratificada, tendo o bloco como um estrato, tem sido constante para os caracteres avaliados ao nível de indivíduos no presente trabalho.

Os coeficientes de variação genética foram iguais a $10,40 \%$ para ambos os locais, indicando a presença de variação genética na população.

Deve-se ressaltar que para Piracicaba o coeficiente de herdabilidade estimado para o caráter índice de formato ultrapas sou o valor máximo considerado por definição ( $100 \%)$. Mesmo o valor estimado para Anhembi pode ser considerado muito elevado. Ocorreu em ambos os locais uma estimativa pequena para a variância fenotípi ca total associada a uma estimativa elevada da variância genética a ditiva. 
64.

Considerando-se que a precisão experimental foi satisfatória, a estimativa de valor inesperado de herdabilidade pode ser atribuída a uma subestimada variância fenotípica dentro de parcelas $\left(\hat{\sigma}_{d}^{2}\right)$, devido à amostragem insuficiente dentro das mesmas. 0 problema de amostragem insuficiente das parcelas pode também ter ocorrido para os outros caracteres de bulbo.

A amostra de dez bulbos por parcela foi a mesma para todos os caracteres avaliados ao nível de indivíduos. A amostragem de dez bulbos pode ser ideal para peso de bulbo, mas não o é necessariamente para os outros caracteres. E difícil então, estabelecer uma única amostra representativa, para todos os caracteres simultaneamente, dentro de parcelas.

Sugere-se, para trabalhos futuros, que se aumente o tamanho da amostra dentro de parcelas, para confirmar ou não os resultados relatados no presente trabalho.

O teor de sólidos solüveis apresentou-se em gradiente no bulbo de cebolas, aumentando das partes externa para a interna e da apical para a basal, como se observa na figura 7. Este resultado vem confirmar o relatado por MELLO et alii (1975).

A correlação positiva e significativa $(r=0,5097)$ en tre os teores de sólidos solúveis das camadas externas e de bulbo como um todo, permite confirmar a validade do método não destrutivo de seleção de bulbos, utilizado no presente trabalho. A amostragem na região de maior diâmetro permite uma avaliação segura do bulbo, e este, após tratamento com fungicidas como benlate, e após ter si- 
submetido a frigorificação, ficará menos sujeito ao apodrecimento no campo.

$$
\text { Para o caráter teor de sólidos solúveis, a população }
$$

$C_{5}$ Baia $\times$ Red Creole apresenta variância genética aditiva, para cada local considerado, como vai demonstrado na tabela 11. Observa-se que em Piracicaba existe maior magnitude que em Anhembi. A diferença entre os valores estimados para os dois locais pode ser atribuída, em parte, a uma possível variação, não isolada das estimativas obtidas, variação essa devida à interação genótipo por ambiente. A estimativa de variância genética aditiva obtida em um só local è su perestimada, pois, associada a ela, encontra-se a variância devidaà interação genótipo por ambiente (GARDNER, 1963; ALLARD, 1971).

A população apresenta possibilidades de sucesso na se leção para teor de sólidos solúveis, para cada local, mesmo utilizan do-se de métodos simples como a seleção massal. A facilidade de seleção ẽ mostrada pelos elevados coeficientes de herdabilidade, de 40,73 e $32,98 \%$, respectivamente para Piracicaba e Anhembi. Os valores estimados da herdabilidade para teor de sólidos solúveis são me nores que os obtidos por WARID (citado por McCOLLUM, 1968), que oscilarám entre 71 e $81 \%$, e também os relatados por McCOLLUM (1968), variando estes entre 78 e $81 \%$.

O teor de sólidos solúveis do bulbo é influenciado por vários efeitos ambientais que, por sua vez, aumentam a variação fenotípica total do caráter. Alguns dos efeitos ambientais que influem no teor de sólidos solúveis são: teor de enxofre no solo 
(KNOTT, 1951), suprimento adequado de ägua, e também competição entre plantas (JONES e MANN, 1963).

O possível sucesso na seleção para teor de sólidos so lúveis é confirmado pelos progressos genéticos esperados, com seleção massal estratificada, para cada local. A seleção feita em Piracicaba oferece possibilidades de sucesso mais rápido, como demonstram seus maiores valores de progresso esperado, para os dois esque mas de seleção massal.

As diferenças encontradas entre os dois locais para progresso genético, herdabilidade e também para os dois esquemas de seleção para um mesmo local, podem ser atribuídas às mesmas causas das diferenças citadas para peso, diâmetro e índice de formato.

A existência de variabilidade genética na população também é demonstrada pelo coeficiente de variação genética, respectivamente de 5,18 e 4,61\% para Piracicaba e Anhembi.

Deve-se ressaltar que a população estudada no presen te trabalho destina-se a ser utilizada como cultivar e/ou para a ob tenção de linhagens para híbridos, de cebola industrial ou de alta conservação 。

A vista dos resultados obtidos, pode-se afirmar que a população presta à seleção intrapopulacional, visando ao aumento dos genes favoráveis para teor de sólidos solúveis. A obtenção de linhagens, visando à produção de híbridos, deverá ser feita quando a população atingir maior teor de sólidos solúveis que o apresentado na geração $C_{5}$. Considerando-se apenas o caráter em questão, o 
coeficiente de variação genética não pode ser considerado elevado. Pode-se esperar que os aumentos do teor de sólidos solúveis não sejam constantes com a seleção. Deve haver um limite fisiológico, associado ao tamanho do bulbo, para o incremento do teor de sólidos solúveis. Na população há bulbos que apresentaram 12-13\% de teor de sólidos solúveis, valores ligeiramente superiores às médias da testemunha parental com maior teor de sólidos solúveis, cultivar Red Creole. Possivelmente, aumentando-se os genes favoráveis para teor de sólidos solúveis, a população atinja, para algumas linhagens,teo res de sólidos solūveis semelhantes à cultivar Red Creole, porém com produtividade superior.

As diferentes estimativas de herdabilidade e de progresso genético esperado para os caracteres de bulbo avaliados ao nível de indivíduos, para os dois locais, podem levar à questão de qual seria o melhor local para se fazer seleção mūltipla, simultânea e eficiente dos caracteres de bulbo de cebola.

JONES e MANN (1963) consideram que a melhor cultivar de cebola é aquela cujos bulbos são selecionados nas condições, sis temas de cultivo e épocas de plantio em que serão posteriormente cul tivadas. A produção de sementes poderá ser feita em outros locais e condições. Assim, pode-se afirmar que a melhor cultivar de cebola a ser obtida da população estudada será aquela selecionada para o local onde a mesma será cultivada. Possivelmente a seleção simultânea de uma cultivar para os dois locais não dará os resultados espera- 
68 .

dos com a seleção feita isoladamente para cada local. Uma possível interação genótipo por ambiente diminuirá a eficiência da seleção da população para os caracteres avaliados considerando-se os dois locais, simultaneamente.

A maneira tradicional de selecionar população de cebola para produção por área e qualidade do bulbo tem sido a seleção de bulbo "per se". Em outras espécies alógamas tem sido utiłizada a seleção através de progênies de meios irmãos, como demonstrado em PATERNIANI (1968), LIMA (1977), DIAS et alii (1971), VELLO (1976) e outros.

A cebola também possibilida a obtenção de progênies de meios irmãos. A vista das estimativas obtidas no presente trabaIho, pode-se sugerir para a cebola o método de seleção entre e dentro de progênies de meios irmãos (PATERNIANI, 1968). No presente tra balho, demonstrou-se a possibilidade de obter ganhos com a seleção entre progênies ou também com a seleção massal dentro das progênies. quando feitas isoladamente.

A vista dos resultados obtidos com milho (PATERNIANI, 1968; LIMA, 1977; ZINSLY, 1969), é de se esperar que o método sugerido possa vir a ser mais eficiente que o da seleção massal, à maneira tradicional. ZINSLY (1969) conduziu um estudo comparativo entre a seleção massal e a seleção entre e dentro de progênies de meios irmãos em milho. Obteve um progresso médio de $6,4 \%$ para a seleção massal e de $13_{0} 8 \%$ para a seleção entre e dentro de progênies de meios irmãos, por ciclo de seleção. 
A utilização de progènies de meios irmãos possibilitaria a realização de um teste de progênies (ALLARD, 1971), tornando a seleção mais segura que a seleção do bulbo "per se". A seleção das melhores progênies poderia ser feita no campo, talvez visualmen te, onde se observariam os caracteres avaliados no presente trabalho ao nivel de parcelas. Posteriormente nas progênies selecionadas seria feita seleção massal, dentro das parcelas, para os caracteres avaliados ao nível de indivíduos. O método sugerido deve acarretar algum trabalho adicional, por ser necessärio manter cada progênie isolada, da colheita de semente, até a avaliação final.

Selecionados os bulbos dentro das melhores progênies. estes seriam frigorificados e plantados no ano seguinte, em um campo isolado, para a recombinação gênica. O plantio em linhas,dos bul bos ao acaso, pode não proporcionar o máximo de recombinação gênica. Poder-se-iam aplicar em linhas alternadas, substâncias gametici das como o relatado em VAN DER MEER e VAN BENNEKON (1973 e 1976).

Nessas linhas é que seriam obtidas as progênies de meios irmãos, a serem avaliadas no próximo ciclo. Outro esquema seria a utilização de plantio com espaçamentos menores, com a escolha ao acaso dos bulbos que dariam as progênies de meios irmãos para o próximo ciclo de seleção.

Um método semelhante ao sugerido, utilizando-se progênies de autofecundação $\left(S_{1}\right)$ foi proposto por JONES e EMSWELLER (1933). A desvantagem desse método é que leva mais tempo que o da seleção massal ou o da seleção entre e dentro de progênies de meios 
70 .

irmãos, para completar um ciclo de seleção.

\section{3 - Correlações entre caracteres de planta e bulbo de cebola}

As correlações entre caracteres evidenciam suas associações. Apesar das correlações poderem ser de causas genéticas e ambientais, somente a correlação genética aditiva constitui uma cor relação herdável e de importância no melhoramento (FALCONER, 1964)。 Segundo ROBINSON et alii (1951) as correlações genéticas e fenotípicas não têm apenas interesse teórico. 0 valor prátí co das correlações é evidente, pois a seleção é relacionada, usualmente, com a mudança de dois ou mais caracteres simultaneamente. En tão, torna-se importante, para o melhoramento, quantificar as relações existentes entre os caracteres e as possiveis respostas correlacionadas da seleção de um carāter, nos outros caracteres.

Como as variâncias e covariâncias dependem da nature za da unidade de seleção (ROBINSON et alii, 1951), os coeficientes de correlação também dependem se a unidade de seleção é ao nível de parcelas ou ao nível de indivíduos.

\subsection{1 - Caracteres avaliados ao nivel de parcelas}

No melhoramento da cebola a produção por área é o ca ráter de maior importância, juntamente com as qualidades de bulbo.

A produção por área mostrou-se correlacionada fenoti picamente, de maneira positiva e significativa, com a sobrevivên- 
cia $\left(r_{\bar{F}}=0,5553\right)$ e também com o número de bulbos comerciais $\left(r_{\bar{F}}=\right.$ $=0,6732$ ), para Anhembi. 0 mesmo não ocorreu em Piracicaba.

As diferenças de comportamento das progênies para a produção por área nos locais considerados, podem ser, em parte, explicadas por uma menor sobrevivência e menor número de bulbos comer ciais em Anhembi. Para Piracicaba a sobrevivência não se mostrou as sociada à produção por área, pois, possivelmente nas progênies de menor sobrevivência, a produção por área foi mantida devido a uma compensação individual das plantas remanescentes. As condições rela tivas a solo, principalmente fertilidade e maior manutenção de umidade para Piracicaba, devem ter favorecido a formação dos bulbos re manescentes que, mesmo em menor número, deram produções stmelhantes às outras progênies com maior sobrevivência. Uma correlação fenotípica positiva entre produção por área e sobrevivência também foi ọ tida por DOWKER et alii (1976).

A produção por área não se mostrou correlacionada fe notipicamente, de maneira significativa, com o número de plantas im produtivas, para nenhum dos dois locais.

E marcante também a correlação fenotípica positiva e significativa, existente entre sobrevivência e número de bulbos comerciais para Piracicaba $\left(r_{\bar{F}}=0,7515\right)$ e Anhembi $\left(r_{\bar{F}}=0,6844\right)$. Essa correlação indica que as progênies que tiveram maiores médias de sobrevivência também tiveram maiores médias de número de bulbos comerciais. A associação entre sobrevivência e número de bulbos comer ciais pode ser explicada, em parte, devido à época favorável ao de- 
senvolvimento de plantas de cebola, na qual foram feitos os ensaios, nos dois locais considerados.

A incidência de plantas improdutivas manifestou-se de maneira aleatória, não estando correlacionada fenotipicamente à pro dução por ārea. Já o nümero de bulbos comerciais mostrou-se correla cionado fenotipicamente, de maneira negativa e significativa, com o número de plantas improdutivas tanto para Piracicaba $\left(r_{\bar{F}}=-0,8126\right)$ como para Anhembi $\left(r_{\bar{F}}=-0,5140\right)$. Esse comportamento entre os dois caracteres é esperado, visto serem caracteres antagônicos. 0 desejā vel é que ocorra sempre o maior nümero de bulbos comerciais por uni dade de ärea.

Das correlações genéticas, a mais importante para o melhoramento é a correlação genética aditiva. Pelas correlações genéticas existentes, pode-se considerar que para Piracicaba a produção por ärea é, geneticamente, resultado de outras componentes, entre elas da sobrevivência e do número de bulbos comerciais. Já para Anhembi, a produção por área mostrou-se associada geneticamente de maneira positiva à sobrevivência e nümero de bulbos comerciais, $e_{\text {o }}$ negativamente, ao nümero de plantas improdutivas. A correlação genê tica positiva entre produção e sobrevivência foi pequena tanto para Piracicaba $\left(r_{A}=0,1678\right)$, como para Anhembi $\left(r_{A}=0,2829\right)$.

Já a correlação genética entre produção por área e nū mero de bulbos comerciais não foi alta para Piracicaba $\left(r_{A}=0,2404\right)$, mas foi elevada para Anhembi $\left(r_{A}=0,8667\right)$. 
A correlação genética positiva entre produção por área e número de plantas improdutivas para o local Piracicaba é de difícil interpretação. Pode ter ocorrido algum erro associado à pre cisão das componentes estimadas, já que o coeficiente de variação pa ra o número de plantas improdutivas foi elevado $(40,88 \%)$, mas, para - local Anhembi, o coeficiente de variação foi mais elevado $(46,63 \%)$ e a correlação genética aditiva entre os mesmos caracteres foi nega tiva $\left(r_{A}=-0,2655\right)$.

A sobrevivência mostrou-se também associada genetica mente de maneira positiva ao número de bulbos comerciais para o local Piracicaba $\left(r_{A}=0,9375\right)$, mas de maneira negativa para o local Anhembi $\left(r_{A}=-0,4935\right)$. Igual comportamento apresentou a associação entre a sobrevivência e o número de plantas improdutivas. A correla ção genética entre sobrevivência e número de plantas improdutivas foi elevada e positiva para Piracicaba $\left(r_{A}=0,7386\right)$, e negativa pa ra Anhembi $\left(r_{A}=-0,3269\right)$.

A correlação genética aditiva entre número de bulbos comercials e número de plantas improdutivas foi elevada e negativa, tanto no local Piracicaba $\left(r_{A}=-0,9463\right)$, como no local Anhembi $\left(r_{A}=\right.$ $=-0,8051) \cdot 0$ comportamento semelhante das correlações genéticas e fenotípicas entre número de bulbos comerciais e número de plantas im produtivas, tanto em magnitude como em sinal, demonstra uma associa ção consistente entre os dois caracteres.

Deve-se ressaltar que muitas das correlações existen tes entre os caracteres avaliados ao nível de parcelas são de difí- 
cil interpretação, principalmente devido aos sinais diferentes entre as mesmas correlações para os dois locais considerados. Värias causas podem estar associadas aos sinais opostos quanto aos locais. para a mesma estimativa. Uma das causas pode ser o erro experimental elevado, obtido nos ensaios de alguns caracteres, como o. nümero de plantas improdutivas, erro esse que não possibilitou a obtenção de estimativas de componentes de variância mais precisas. A outra possível causa deve estar relacionada à existência de interações genótipo por ambiente, não isoladas das estimativas de variāncia e de covariāncia.

No presente trabalho as variâncias e covariāncias fo. ram estimadas a partir de dois experimentos, conduzidos em dois 10cais isoladamente, e em época favorável ao cultivo da cebola. Portanto, como o discutido por DUDLEY e MOLL (1969), as estimativas dos componentes de variāncia para os caracteres avaliados, em um só local ou época, ao nível de parcelas ou ao nível de indivíduos, incluem, além do valor dos componentes, os valores devidos às interações das progênies por locais e também por épocas. As interações podem ser a causa de superestimação dos componentes de variância. Já os componentes de covariāncia poderão estar sub ou superestimados.

A não realização de análises conjuntas para o mesmo caráter, nos dois locais, impossibilitou a obtenção de estimativas isentas da interação por locais. A não realização de ensaios nas di ferentes épocas de cultivo tornou impossível a obtenção de estimati vas isentas da interação por épocas. 
Trabalhos futuros deverão confirmar, ou não, as possiveis causas das discrepânciàs de sinais e os valores de correlações genéticas obtidas no k̉resente trabalho.

Considerando-se os valores de herdabilidade e correlações genéticas aditivas obtidos neste trabalho, e também a estrutura do método de seleção sugerido, o de seleção entre progênies de meios irmãos, utilizando-se de quatro repetições, pode-se esperar a existência de respostas correlacionadas.

Pode-se esperar que, para as condições do local Pira cicaba, ocorra uma resposta correlacionada na produção por área, ca ráter de maior importância, através da seleção para maior nümero de bulbos comerciais, tendo em vista o coeficiente de correlação genética aditiva entre os caracteres $\left(r_{A}=0,2404\right)$ e a herdabilidade pa ra o nümero de bulbos comerciais $(23,88 \%)$.

A existência de correlação genética aditiva e de alto valor de herdabilidade para o caráter a ser selecionado, são con dições para a ocorrência de resposta correlacionada, segundo DEMPSTER (1963)。

Porém, como argumenta FALCONER. (1964), a resposta cor relacionada serã mais efetiva que a seleção direta $(\Delta G)$, quando $\hat{r}_{A(x, y)} \cdot \hat{f}_{y}>\hat{h}_{x}$, onde, $\hat{r}_{A(x, y)}$ é o coeficiente de correlação gené tica aditiva, entre os caracteres $x$ e $y: f_{y}$ e $f_{x}$ são as raízes quadradas das estimativas das herdabilidades para os caracteres $x$ e $y$. respectivamente. Seguindo o argumento de FALCONER (1964), a seleção direta para a produção por área, no local Piracicaba, será mais efe 
tiva que a seleção indireta através de outros caracteres associados geneticamente a ela. 0 fato vem consubstanciar a idéia de que a pro dução final por área é um caráter complexo, que engloba outros à ma neira de um Índice de seleção. Cada componente da produção é associado a outro componente, isto é, sobrevivência, número de bulbos comerciais e outros, de maneira que a seleção isolada para cada com ponente não dará resultados mais compensadores que a seleção da pro dução por área "per se" .

Utilizando-se do mesmo argumento de FALCONER (1964). pode-se esperar um aumento mais elevado na sobrevivência no local Piracicaba através da seleção para aumento do nümero de bulbos comerciais, ou ainda, para diminuição do nümero de plantas improdutivas. Para Anhembi, pode-se esperar aumento na produção por ärea por meio da seleção para sobrevivência ou nümero de bulbos comerciais, ou diminuição do número de plantas improdutivas. A semelhança de Pí racicaba, nenhuma seleção para qualquer componente da produção será mais efetiva que a seleção direta, na produção por área, seguindo o argumento de FALCONER (1964).

A sobrevivência poderá ser mais facilmente elevada para Anhembi, através da seleção para diminuir o número de plantas improdutivas. A possibilidade de resposta correlacionada efetıva ē devida à correlação genética aditiva entre os caracteres $\left(r_{A}=-0,3269\right)$ e também à alta herdabilidade para o nümero de plantas improdutivas $(52,39 \%)$ 
As considerações acima demonstram que a seleção entre progênies para produção por área é mais efetiva quando feita dí retamente, selecionando-se aś progênies com maior produção por ärea, para cada local considerado.

\subsection{2 - Caracteres avaliados ao nivel de individuos}

As correlações fenotípicas entre os caracteres de bul bo, avaliados ao nível de indivíduos, encontram-se na tabela 22.

A correlação fenotị́pica entre peso e diâmetro do bu bo foi negativa, sendo de $-0,1930$ para o local Piracicaba e -0,3559 para o local Anhembi. Os valores obtidos não concordaram com os relatados por McCOLLUM (1966, 1968 e 1971), os quais foram positivos e elevados.

Entre peso e indice de formato, a correlação fenotípica foi de -0,8538 para Anhembi. Para.Piracicaba foi superior ao seu valor máximo, que por definição é o valor um. A obtenção de um valor inesperado, isto é, superior a l, pode ser atribuída a värias causas ou à reunião de värias delas. Uma das causas pode ser a amos tragem insuficiente dentro de parcelas, o que resultaria em um componente errado, tanto na variância como na covariância, apesar de que amostras de dez bulbos foram suficientes tanto para peso como para outros caracteres do bulbo.

Outra causa pode ser a existência de elevados desvios padrão associados a cada estimativa de componente, não calcula dos no presente trabalho. 
Uma possível interação genótipo por ambiente pode ser outra fonte de erro. No presente trabalho não foram obtidas componen tes devido a interações, que permaneceram associadas às componentes de variância e covariância, pois não foi feita nenhuma análise conjunta de caracteres, para os dois locais.

A correlação fenotípica negativa entre peso e índice de formato evidencia que os bulbos mais pesados tiveram o formato mais chato, característica desejável em cebolas para fins industriais (JONES e MANN, 1963)。

Deve-se ressaltar que a população se destina à produ ção de híbridos, ou à utilização direta como cultivar de cebola objetivando o processamento industrial de desidratação.

As correlações fenotípicas obtidas entre peso e índi ce de formato concordaram em sinal com os valores relatados por McCOLLUM (1966, 1968 e 1971) em dezessete populações de cebola de dias longos, porém os valores foram menores que os do presente irabalho. KOBABE (1968) também observou uma correlação fenotípica negativa en tre peso e índice de formato, para outra população.

A correlação fenotípica entre peso e teor de sólidos solúveis foi negativa para os dois locais, sendo elevada para Piracicaba $\left(r_{F}=-0,8561\right)$ e menor para Anhembi $\left(r_{F}=-0,2685\right)$. Os valores de correlação fenotípica entre peso e teor de sólidos solúveis encontrados diferem em magnitude e sinal do relatado por McCOLLUM (1968), que foi de 0,317, para uma população da cultivar de dias longos, a White Sweet Spanish. 
Entre diâmetro e índice de formațo, a correlação fenotípica foi negativa para Piracicaba $\left(r_{F}=-0,4965\right)$ e positiva para Anhembi $\left(r_{F}=0,2991\right)$. O valor obtido para Piracicaba foị concor dante em sinal, porém menor em magnitude, para as estimativas obtidas por McCOLLUM (1966)para seis populações de cebola de dias longos. Também houve concordância em magnitude e sinal da correlação fenotípica entre diâmetro e índice de formato, estimada em Piracica ba, com a relatada por McCOLLUM (1968) para uma população da culti var White Sweet Spanish. McCOLLUM (1971) também estimou correlações fenotípicas negativas entre diâmetro e índice de formato, para dez populações de cebola de dias longos. Para uma população, o valor es timado foi igual ao obtido no presente trabalho: já para as outras nove populações, os valores estimados foram maiores.

Em Anhembi os bulbos apresentaram uma correlação fenotípica positiva entre diâmetro e índice de formato. Devem ter apresentado alturas maiores que o diâmetro, de maneira não proporcio nal, resultando uma associação tal que, quanto maior o diâmetro,mai or ainda a altura, e consequentemente mais elevado o índice de formato.

Os caracteres diâmetro e teor de sölidos solüveis apresentaram-se correlacionados fenotipicamente de maneira negativa. tanto para Piracicaba $\left(r_{F}=-0,1032\right)$, como para Anhembi $\left(r_{F}=-0,1151\right)$.

Convém ressaltar que a região amostrada no bulbo foi a de maior diâmetro: e como o relatado anterịormente, o teor de sốlidos solüveis varia em gradiente nọ hułḅo, sendo menor nas camadas 
externas, como pode ser observado na figura 7. Mas existe uma corre lação significativa entre teor de sólidos solúveis da parte externa com o teor do bulbo como um todo.

As correlações fenotípicas entre diâmetro e teor de sólidos solúveis obtidos no presente trabalho discordaram, tanto em em sinal como em magnitude, da estimativa obtida por McCOLLUM(1968), que foi de 0,273 .

0 indice de formato apresentou-se correlacionado fenotipicamente com o teor de sólidos solúveis, de maneira negativa para Piracicaba $\left(r_{F}=-0,1581\right)$ e de maneira positiva para: Anhembi $\left(r_{F}=0,1554\right)$. 0 valor estimado para Piracicaba foi semelhante ao obtido por McCOLLUM (1968) para uma população de cebola de dies lon gos, o qual foi de $-0,147$.

As diferenças de sinal para a mesma correlação, para cada local, podem ter värias causas. A amostragem insuficiente dentro de parcelas e a existência de interações genótipo por ambiente podem ser duas dessas causas.

Como jä foi citado anteriormente, para o melhoramento as correlações importantes são as genéticas aditivas.

Entre peso e diâmetro de bulbo, a correlação genética aditiva foi elevada e negativa para Piracicaba $\left(r_{A}=-0,9622\right)$ e baixa e positiva para Anhembi $\left(r_{A}=0,2529\right)$. Significa que, fazendo-se a seleção para aumento do peso do bulbo em ambos os locais, poderão ocorrer modificações diferentes no diâmetro do bulbo, diminui indo em Piracicaba e aumentando em Anhembi. Os valores obtidos no 
presente trabalho não concordam com os obtidos por McCOLLUM (1966, 1971), nem em sinal, nem em magnitude. Para quatro populações de ce bola de dias longos, os valores obtidos por McCOLLUM (1966) variaram entre 0,753 a 0,985; para outras dez populações os valores também foram elevados (McCOLLUM, 1971).

As correlações genéticas e fenotípicas dependem da população estudada e do ambiente considerado. No presente trabalho, a população e os ambientes estudados diferem dos relatados na literatura.

A correlação genética aditiva entre peso e índice de formato, para Anhembi foi positiva, e pode ser considerada elevada $\left(r_{A}=0,6453\right)$. Para as condições do mesmo local, a seleção para maí or peso de bulbo poderá resultar em uma elevação do índice de forma

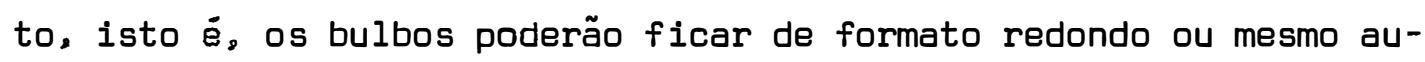
mentar a altura não proporcionalmente ao diâmetro, tornando-se peri formes.

Para Piracicaba a correlação genética aditiva entre peso e indice de formato ultrapassou o valor um, mesmo considerando-se o erro da estimativa. O valor inesperado superior a 1 pode ser atribuído a vários fatores. Um deles pode ser estimativas de componentes de variância e covariāncia não reais, devido a amostragem in satisfatöria dentro de parcelas, para um dos caracteres. Como o dis cutido anteriormente, uma amostra de dez bulbos talvez seja insuficiente para avaliar a variação e a covariação dentro de parcelas de maneira simultânea e eficiente para värios caracteres de bulbo. 
Outro fator pode estar associado ao erro da estimati va, já que o valor obtido para o desvio padrão da correlação genéti ca aditiva é aproximado. Pode ser que a correlação seja alta, próxí ma ao valor um, porém, devido a aproximação do erro da estimativa,o valor mais real talvez não seja englobado pelo intervalo de confian ça.

Outro fator que pode estar associado à estimativa fora do intervalo de valores, o qual, por definição para coeficiente de correlação estã entre $-1 \leq r_{A} \leq 1$, é uma possível interação genó tipo por ambiente, não isolada dos componentes de variância e covariância no presente trabalho.

A correlação genética aditiva obtida em Anhembi para peso e índice de formato não concordou com a obtida por McCOLLUM (1966, 1968 e 1971) para dezesseis populações de cebola. Porém, outra população estudada pelo mesmo autor apresentou uma correlação ge nética aditiva semelhante $\left(r_{A}=0,501\right)$ à obtida no presente traba1ho.

O caráter peso e teor de sólidos solúveis apresentou as correlações genéticas aditivas de $-0,6983$ para Piracicaba e de -0,3954 para Anhembi. A semelhança de sinais entre as correlações ge néticas e fenotípicas para peso e teor de sólidos solúveis, demonstra a consistência das correlações para ambos os locais. McCoLLUM (1968) também estimou uma correlação negativa entre peso e teor de sólidos solūveis, para uma populaçã́o da cultivar de dias longos, a White Sweet Spanish. Porém, o valor obtido, isto é, $-0,879$, foi mais 
alto que os obtidos no presente trabalho.

A correlação genética negativa entre peso e teor de sólidos solúveis mostra que a seleção para maior peso do bulbo pode rá trazer uma diminuição no seu teor de sólidos solúveis.

Os caracteres diâmetro e índice de formato apresentaram-se correlacionados geneticamente de maneira negativa, tanto para Piracicaba $\left(r_{A}=-0,4175\right)$, como para Anhembi $\left(r_{A}=-0,6189\right)$. Isso demonstra que a seleção para aumento do diâmetro poderá resultar em bulbos mais chatos, devido à diminuição do índice de formato.

As correlações genéticas entre diâmetro e índice de formato obtidas no presente trabalho concordaram em sinal e, para algumas populações, também em magnitude, com as correlações estimadas para os mesmos caracteres por McCOLLUM (1966, 1968 e 1971), em dezessete populações de cebola. Nessas populações os valores variaram entre $-0,496$ e $-0,788$.

A correlação genética aditiva entre diâmetro e teor de sólidos solúveis variou com o local, sendo de 0,1401 para Piraci caba e -0,4732 para Anhembi. A discrepância entre os sinais pode ser atribuída aos fatores já mencionados anteriormente, entre eles a in teração genótipo por ambiente.

A correlação genética aditiva entre diâmetro e teor de sólidos solúveis estimada para os bulbos em Anhembi foi semelhan te em sinal à obtida por McCOLLUM (1968), que foi de -0,610, mas dis corda ligeiramente em magnitude. O mesmo não ocorreu com a correlação genética estimada para os bulbos em Pịpacioạpa, que foi positi- 
va, embora pequena.

Foi negativa a correlação genética aditiva existente entre índice de formato e teor de sölidos solúveis, tanto para os bulbos obtidos em Piracicaba $\left(r_{A}=-0,6495\right)$ como para os obtidos em Anhembi $\left[r_{A}=-0,2480\right)$. Os valores estimados são diferentes em magnitude, mas iguais em sinal, à correḷação genética aditiva obtida por McCOLLUM (1968), a qual foi de $-0,147$, para os mesmos caracteres.

Vărios fatores podem dificultar a interpretação de algumas correlações genēticas, ou fazer estimá-las erradamente. Den tre esses fatores se colocariam o número de progênies de meios irmãos avaliadas, alguns baixos coeficientes de herdabilidade, um pos sível erro de estimativa devido a amostragem insuficiente, e também, a existência de interações genōtipo por ambiente, tanto por locais como por épocas.

Segundo VANVLECK e ANDERSON (1961), mesmo mil pares de observações podem ser insuficientes para se obterem estimativas precisas de correlações genéticas, especialmente quando a herdabili dade é baixa. McCOLLuM (1966, 1968 e 1971) estimou correlações entre caracteres de bulbo, utilizando-se de populações pequenas, que variaram de 17 a 89 progênies $S_{1}$, ou de progênies de meios irmãos. No presente trabalho, as estimativas foram obtidas a partir da avaliação de 54 progênies de meios.irmãos, um número intermediário ao utilizado por outros autores. 
Deve-se ressaltar a dificuldade de se avaliar individualmente, bulbo a bulbo, um grande nümero de progênies, utilizando-se de vārias repetições. Uma alternativa seria diminuir o número de repetições para no mínimo duas, o que possibilitaria aumentar-se o nümero de progênies passíveis de avaliação individual. Tam bém possibilitaria o aumento do nümero de bulbos avaliados dentro de parcelas.

Estimativas de correlação genētica aditiva entre teor de sólidos solúveis e outros caracteres do bulbo são apenas re latadas por McCOLLUM (1968), servindo para comparações com os valores obtidos no presente trabalho.

Considerando-se os valores de correlação genētica aditiva obtidos no presente trabalho e o fim a que se destina a popu lação, ou seja, o de obter híbrido ou cultivar de cebola com elevado teor de sölidos solúveis, podem-se prever algumas dificuldades e facilidades nos trabalhos de seleção da população.

As características consideradas importantes para uma cebola industrial são: produção satisfatória por área, formato chato, alto teor de sólidos solúveis, alta conservação e coloração bran ca.

A seleção massal para peso individual de bulbos dará resultado em Piracicaba, como demonstra o valor elevado de herdabilidade para esse caráter $(39,09 \%)$.

Em condições como as de Anhembi, métodos simples como a seleção massal não serão eficientes para aumentar o peso indi- 
86.

vidual e, conseqüentemente, a produção por ärea, devido à baixa her dabilidade.

0 aumento do teor de sölidos solụvveis também serápos sível, mesmo utilizando-se da seleção massal, em ambos os locais.

0 aumento de peso de bulbo e de teor de sólidos solü veis será dificultado se feito simultaneamente. A correlação genēti ca aditiva é negativa entre os dois caracteres, tanto para Piracica ba $\left(r_{A}=-0,6495\right)$, como para Anhembi $\left(r_{A}=-0,2480\right)$.

Isso significa que a seleção para aumento de teor de sólidos solúveis trará no.peso do bulbo uma resposta correlacionada negativa, para os dois locais. A diminuição do peso do bulbo poderá resultar em uma diminuição da produção de bulbos por área, o que é uma desvantagem para o agricultor, que vende sua produção por peso. Por outro lado, aumentará o rendimento industrial e a conservação dos bulbos. Portanto, é necessārio alcançar-se um teor não muito elevado de sólidos solúveis, associado a um peso de bulbo que não di minua a produção por área, considerando-se a densidade de plantas $\underline{u}$ tilizadas no presente trabalho $(200.000$ plantas por ha).

Se a cultivar ou o híbrido se destinar apenas à utilização industrial, o melhoramento poderá ser dirigido para o aumen to do teor de sölidos solúveis.

A influência da diminuição do peso do bulbo na produ ção por área poderá ser, em parte, anulada pelo aumento da densidade populacional nos cultivos comerciais. O objetivo seria então de se obter a maior produção de sólidos solúveis por área, não impor- 
tando o peso do bulbo.

Quanto ao formato, não haverá problemas no melhoramento, pois a correlação genética aditiva entre índice de formato e teor de sólidos solúveis é negativa para os dois locais. Significa que a seleção para alto teor de sólidos solúveis poderá resultar em uma diminuição no Índice de formato, com os bulbos se tornando mais chatos, o que é desejāvel em cebola industrial, pois é melhor a aco modação de bulbos no armazenamento a granel. 
88.

\section{CONCLUSÖES}

Com base nos resultados obtidos na população $C_{5}$ Baia Periforme Precoce $\times$ Red Creole, utilizando-se de progênies de meios irmãos, pode-se concluir no presente trabalho que:

1 - Há na população variabilidade genética aditiva para todos os caracteres estudados, à exceção de sobrevivência.

2 - Considerando-se seleção entre progênies de meios irmãos,al tas herdabilidades foram estimadas para produção por área e número de plantas improdutivas; herdabilidade média para número de bulbos comerciais, e baixa herdabilidade para sobrevivência. Todos os caracteres de bulbo, avaliados ao nível de individuos, apresentaram . em geral, herdabilidades elevadas.

3 - As correlações fenotípicas significativas para caracteres ao nível de parcelas foram entre produção por ärea e sobrevivência: 
e produção por area e numero de bulbos comerciais, considerando-se o local Anhembi. A correlação fenotípica entre sobrevivência e número de bulbos comerciais, e entre sobrevivência e número de plantas improdutivas, foi significativa para ambos. os locais considerados.

4 - Para os caracteres avaliados ao nível de parcelas, as correlações genéticas aditivas elevadas foram entre produção por ärea e número de bulbos comerciais para o local Anhembi; entre sobrevivência e número de bulbos comerciais, e entre sobrevivência e núme ro de plantas improdutivas para o local Piracicaba. A correlação ge nética aditiva entre número de bulbos comerciais e número de plan tas improdutivas foi elevada e negativa para os dois locais.

5 - As correlações fenotípicas mais elevadas entre caracteres avaliados ao nível de indivíduos foram entre peso e teor de sólidos solúveis e entre diāmetro e Índice de formato, ambos de maneira negativa para o local Piracicaba: $e_{1}$ também de maneira negativa, en tre peso e índice de formato para o local Anhembi.

6 - Para os caracteres avaliados ao nível de indivíduos, as maiores correlações genéticas aditịvas foram entre peso e diâmetfo de bulbo, entre peso e teor de sólidos solúveis e entre índice de formato e teor de sólidos solúveis, todos de maneira negativa para - local Piracicaba. Para Anhembi, as correlações também foram negativas entre os caracteres peso e índice de formato, diâmetro e índi ce de formato, e diâmetro e teor de sólidos solúveis. 
90.

7 - Há correlação fenotípica positiva e significativa entre o teor de sólidos solüveis das camadas externas do bulbo, obtida por técnicas não destrutivas, com o teor total de sólidos solúveis do bulbo. 
91.

8. SUMMARY

Heritability plus genetic and phenotipic correlations are genetic statistic parameters which characterize genetic variability and characteres association among poligenic characteres. This research aimed the estimation of heritabilities and correlations among plant and bulb onion characteres, for $C_{5}$ population of Baia Periforme Precoce versus Red Creole crossing. It was used 54 half-sib progenies, evaluated in two locations, Piracicaba and Anhembi $123^{\circ}$ latitude South), at the most favorable onion growing season, i.e., seeding in May. Characteres evaluated at plot level were: yield, survival, unproductive plants, commercial bulbs. Characteres evaluated at individual level, based on sample of ten bulbs per plot, were: weight, diameter, shape index, and solid soluble percentage. The experimental design was in randomize blocks, with four replications. Genetic parameters were estimated through variance components and 
covariance. Characteres heritabilities evalueted at plot level were estimated based on half-sib progenies means. The highest heritabilities were for yield per area unit: 67.63 and $41.64 \%$; plant unproductive number: 39.92 and $52.39 \%$. respectively for Piracicaba and Anhem bi. It was positive the phenotipic correlation based on progenies mean between yield and survival, yield and commercial bulb number. It was negative between commercial bulb number and unproductive plants number for Anhembi location. For Piracicaba, the significative phenotipic correlation was positive between' survival and commercial bulb number, but negative between commercial bulb number and unproductive plants number. The highest additive genetic correlations among progenies were: survival versus commercial bulbs number: 0.9375 and -0.4934 ; and commercial bulbs number versus improduc tive plants number: -0.9436 and -0.8051 respectively for Piracicaba and Anhembi. The highest bulb characteres heritabilities were: weight: 39.09 and $12.01 \%$ : and solid soluble percentage: 40.73 and 32.98 respectively for Piracicaba and Anhembi. The heritability for shape index was $99.57 \%$ for Anhembi location. The highest phenotipic correlations among characteres at individual level were between weight and solid soluble percentage: -0.8561 and -0.2685 ; diameter and shape index: -0.4965 and 0.2991 . The highest genetic correlation for bulb characteres were between weight and diameter: -0.9622 and 0.2529; weight and soluble solid percentage: -0.6983 and -0.3954 ; diameter and shape. index: -0.4175 and -0.6189 , respectively for Piracicaba and Anhembi. Onion breeding for yiæld increase is promis- 
ing by selecting the best half-sib progenies or mass selection within progeny.

The $C_{5}$ population Baia versus Red Creole shows genetic variability for the majority of considered characteres. 
94.

\section{LITERATURA CITADA}

AlLLARD, R.W., 1971. Princípios do Melhoramento Genético das Plantas. São Paulo, Edgard Blücher Ltda. 381 p.

BACON, J.S.D., 1957. The water-soluble carbohydrates of the onion, Allium cepa L. Biochemical Journal. Cambridge, 67: 5-6.

BREWBAKER, J.L。, 1969. Genética na Agricultura. São Paulo. Polígo no e Editora da Universidade de São Paulo. $224 \mathrm{p}$.

CARMO, C.M. , 1969. Avaliação de Progênies de Meios Irmãos em Populações Heterogêneas de Milho (Zea mays L。). Piracicaba, ESALQ/ USP, 48 p. (Dissertação de Mestrado)。

COCKERHAM, C.C., 1963. Estimation of Genetic Variances. In: HANSON, W.D. e H.F. ROBINSON, Ed. Statistical Genetics and Plant Breeding. Washington, National Academic Science - National Research Council, p.53-93. 
CONCEIÇÃO, F。A.D。, 1972. Influência da Cobertura Morta e de Diferentes Tensões de Unidade do Solo no Comportamentọ da Cultura da Cebola (AZZium cepa L.) pelo Processo do Bulbinho. Piracicaba, ESALQ/USP, 184 p. (Tese de Doutoramento)。

DEMPSTER, E。R。 1963. Concepts and Definitions in Relation to Selection Schemes. In: HANSON, W.D. e H.F. ROBINSON, Ed. Statistical Genetics and Plant Breeding. Washington, National Academic Science - National Research Council, p. 125-139.

DIAS, M。 e C.P. COSTA, 1967. Eficiència de um ciclo de seleção mas sal contra florescimento prematura na variedade de cebola Barrei ro. In: VII Reunião An. da Soc. de Dlericultura do Brasil. 2p. Mimeografado。

DIAS, M。 e C.P. COSTA 1970. Programa de melhoramento da cebola (AZlium cepa $L_{0}$ ), em andamento no Setor de Melhoramento de Horta liças. Inst, de Genética. ESALQ/USP, Piracicaba.6p. Mimeografado.

DIAS, M。: R。 VENCOVSKY e C.R.M. GODOI, 1971. Seleção entre e dentro de famílias de meios irmãos em brocoli ramoso (Brassica oleracea var. italica L., cultivar Santana). Rel. Cient. Inst. Genética. ESALQ/USP, Piracicaba, 5: 57-62.

DOWKER, B.D॰: R.C: HARDWICK; J.F.M. FENNELL \& D.J. ANDREWS, 1976. Genotypic and environmental correlations between leaf growth and bulb size in onions. Annals of Applied Biology。 Cambridge, 82: 341-348。

DUDLEY, J.W. e R.H. MOLL, 1969. Interpretation and use of estimates of heritability and genetic variances in plant breeding. Crop Science. Madison, 9: 257-262. 
FALCONER, D.S. 1964. 'Introduction to Quantitative Genetics. 3a ed。 London, Oliver and Boyed Ltda. 365 p.

FISHER, R。H。 e F。 YATES, 1971. Tabelas Estatisticas: para Pesquisa em Biologia, Medicina e Agricultura. Editora Polígono e Editora da Universidade de São Paulo. São Paulo, 150 p.

FOSKETT, R.L。 e C.E。 PETERSON, 1950. Relation of dry matter content to storage quality in some onion varieties and hybrids. Proceedings of the American Society for Horticultural Science. East Lansing, 55: 314-318.

GARDNER, C.0., 1963. Estimates of Genetics Parameters in Cross-Fertilizing Plants and their Implications in Plant Breeding. In: HANSON, W.D. e H.F. ROBINSON, Ed, Statistical Genetics and Plant Breeding。 Washington, National Academic Science-National Research Council, P. 225-249。

HANSON, W.D., 1963. Heritability。 In: HANSON, W.D. e H.F. ROBINSON, Ed. Statistical Genetics and Plant Breeding. Washington, National Academic Science - National Research Council, p. 125-139.

JONES, H.A. e L.K. MANN, 1963, Onions and their Allies, New York, Leonard Hill Books. 286 p.

JONES, H.A. e S.L. EMSWELLER, 1933. Methods of Breeding Onions. Hilgardia. Berkeley, $\underline{7}$ : 625-642。

KEMPTHORNE, 0., 1966. An Introduction to Genetic Statistic. 3? ed. New York, John Wiley \& Sons, 545 p.

KNOTT, J.E., 1951. Palestras sobre Horticultura, (s.1.), Reitoria da USP, $214 \mathrm{p}$ 。 
KOBABE, G., 1968. Beziehungen $z$ wischen standweite, zwiebelgewicht and zwiebelform bei AZZium cépa L. . Z. Pflanzenzucht. Berlin, 60: 102-112.

LIMA。 M。 , 1977. Seleção Entre e. Dentro de Famílias de Miios Irmãos na População de Milho (Zea mays L。) ESALQ-VD 2. Piracicaba, ESALQ/USP, 71 p. (Dissertação de Mestrado).

LONNQUIST, J。H. 1965. Métoḍos de selección útiles para mejoramien to dentro de poblaciones. Fitotecnia Latinoamericana. Lima, 2 : 1-10.

MANN, L.K. e B.J. HOYLE, 1945: Use for the refractometer for selecting onions bulb high in dry matter for breeding. Proceedings of the American Society for Horticultural Science. New York, 46: 285-292.

McCOLLUM, G.D., 1966. Heritability and genetic correlation of some onion bulb traits. Estimates from $S_{1}$ offspring-on-parent regression. Journal of Heredity. Baltimore, 57: 105-110.

McCOLLUM, G.D., 1968. Heritability and genetic correlation of soluble solids bulb size and shape in White Sweet Spanish onion. Canadian Journal of Genetics and Cytology. Ottawa, 10: 508-514.

McCOLLUM, G.D., 1971. Hereditability of onion bulb shape and size estimating from half-sib families. Journal of Heredity. Baltimore, 62: 101-104。

MELO, P.C.T. et alii, 1975. Estudos preliminares sobre o teor de só lidos solúveis de alguns cultivares de cebola (AZZium cepa $L_{0}$ ) no submédio São Francisco. In: III Seminário Nacional de Irrigação e Drenagem. Fortaleza.5p. Mimeografado. 
NAKAMURA, No, 1959. Studies on the breeding of AZZium cepa $L_{0}$ (I)

- Estimating heritability. Japanese Journal Breeding, 8: 255-260. In: Plant Breeding Abstracts, 29, $n^{8} 4538$.

NAKAMURA, No e M. TERABUN, 1956. Studies on seed production of the onion. II Genotypic Correlations of mother plants. Hyogo Noka Daigaku Ken Kyu Hokoko. Nogaku Heny Sci. Rep. Hyogo Univ. Agr. Ser.Agr. 2: 174-176。 In: Plant Breeding Abstracts.29, $\pi^{8} 4537$.

PATERNIANI, E。, 1968. Avaliação do Método de Seleção entre e dentro de Famílias de Meios Irmãos no Melhoramento de Milho (Zea mays L.). Piracicaba, ESALQ/USP, 92 p. (Tese de Professor Catedrático).

PATERNIANI, E。, 1974. Estudos Recentes sobre Heterose. S. Paulo, Fundação Cargill, 36 p.

PIMENTEL GOMES, F。, 1973. Curso de Estatística Experimental. 5. ed. Piracicaba, Editora Nobel, $430 \mathrm{p}$.

QUEIROZ, M。A。, 1969. Correlações Genéticas e Fenotípicas em Progênies de Meios Irmãos de Milho (Zea mays $L_{0}$ ) e suas Implicações com o Melhoramento. Piracicaba, ESALQ/USP, 71 p. CDissertação de Mestradol.

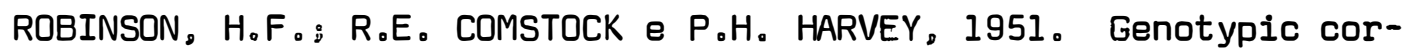
relations in corn and their implications in selection. Agronomy Journal. Madison, 43: 282-287.

SCHWEISGUTH, B。, 1974. Etude de la teneur en matière seche de l'oignon, Alzium cepa L. II. Heredité de la teneur em matière seche du bulbe. Annales de l'Amélioration des Plantes. Versailles, 24: 185-196. 
SINGH, R. e R。B。ALDERFER, 1966. Effects of soil-moisture stress at different periods of growth of some vegetable crops. Soil Science. New Brunswich, 101: 69-80.

STEBBINS, G.L。, 1957. Self-fertilization and population variability in the higher plants. Amer. Nat。 Lancaster, 91:337-354。

STEEL, R.G.D. e J.H. TORRIE, 1960. Principles and Procedures of Statistics, with Special Reference to the Biological Sciences. New York, McGraw Hill. 481 p.

VAN DER MEER, Q。P。e J.L. VAN BENNEKON, 1968. Research on pollen distribution in onion seed fields. Euphytica. Wageningen, 17: 216-219.

VAN DER MEER, Q.P。 e J.L. VAN BENNEKON, 1973. Gibberellic acid as a gametocide for the common onion (AlZium cepaL.). Euphytica. Wageningen, 22: 239-243.

VAN DER MEER, Q.P。 e J.L. VAN BENNEKON, 1976. Gibberellic acid as a gametocide for the comnon onion (Allium cepa $L_{0}$ ). II. The efr fect of GA 4/7. Euphytica. Wageningen, 25: 293-296.

VANVLECK, L。D。 e C.R. HENDERSON, 1961. Empirical sampling estimates of genetic correlations. Biometrics. Oak Ridge, 17: 359-371.

VELLO, N.A. . 1977. Seleção Dentro de Progênies e Recombinação por Policruzamento em Couve-Brócolos Ramosa (Brassica oleracea L. var. italica Plenck). Piracicaba, ESALQ/USP, 88 P. (Tese de Doutoramento\}.

VELLO, N.A。 e R。 VENCOVSKY, 1974. Variâncias associadas às estimativas de variâncias genéticas e coeficlentes de herdabilidade. 
100 .

Rel.Cient.Inst. Genética. ESALQ/USP.Piracicaba, 8: 238-248.

VENCOVSKY, R。 1969. Genética Quantitativa. In: KERR, WoE。, Org; Melhoramento e Genética. São Paulo, Edições Melhoramentos, P. 17-18。

YOKOYAMA, S., 1976. Comportamento de Populações de Cebola Baia Periforme (AlZium cepa L.), com relação a Épocas e Técnicas de Cul tivo. Piracicaba, ESALQ/USP, 77 p. (Dissertação de Mestrado).

ZIMMERMANN, M.J.O., 1973. Efeitos da Autofecundação na Variedade de Cebola Barreiros (AlZium cepa L。) 。Piracicaba, ESALQ/USP, 97 P. (Dissertação de Mestrado)。

ZINSLY, J.R. s 1969. Estudo Comparativo Entre a Seleção Massal e a Seleção Entre e Dentro de Famílias de Meios Irmãos em Milho (Zea mays L.).Piracicaba, ESALQ/USP, 88 po (Tese de Doutoramento). 
101.

APENDICE I

T A B E L A S 
102.

Tabela 1 - Modelo da Análise de Variância, no Delineamento de Blocos ao Acaso, para Caracteres ao Nível de Parcelas, e as Respectivas Esperanças Matemáticas dos Quadrados Médios, Considerando-se um Local.

\begin{tabular}{lccc}
\hline Fonte de Variação & G.L. & $Q_{0} M_{0}$ & $E\left(Q_{0} M_{0}\right)$ \\
\hline Blocos & $r-1$ & - & - \\
Progênies & $p-1$ & $Q_{2}^{\prime}$ & $\hat{\sigma}_{e}^{2}+r \hat{\sigma}_{p}^{2}$ \\
Erro & $(r-1)(p-1)$ & $Q^{\prime}$ & $\hat{\sigma}_{e}^{2}$ \\
\hline
\end{tabular}

onde: G.L. = graus de liberdade:

Q.M. = quadrado médio;

$E\left(Q . M_{.}\right)$= esperança matemática dos quadrados médios;

$r=$ nümero de repetições;

$p=$ número de progênies de meios irmãos;

$Q_{1}^{\prime}=$ quadrado médio do erro entre parcelas;

$Q_{2}^{\prime}=$ quadrado médio entre progênies, ao nível de parcelas:

$\hat{\sigma}^{2}=$ variância do erro entre parcelas;

$\hat{\sigma}_{p}^{2}=$ variância genética entre progênies de meios irmãos,ao nível de parcelas. 
Tabela 2 - Modelo da Análise de Variância, no Delineamento de Blocos ao Acaso, para Caracteres ao Nível de Indivíduos, e as Respectivas Esperanças Matemáticas dos Quadrados Médios, Considerando-se um Local.

\begin{tabular}{lccc}
\hline Fonte de Variação & G.L. & $Q_{0} M_{0}$ & $E(Q . M)$. \\
\hline Blocos & $r-1$ & - & - \\
Progênies & $p-1$ & $Q_{3}$ & $\sigma_{d}^{2}+k \sigma_{e}^{2}+r k \sigma_{p}^{2}$ \\
Erro entre Parcelas & $(r-1)(p-1)$ & $Q_{2}$ & $\sigma_{d}^{2}+k \sigma_{e}^{2}$ \\
Dentro de Parcelas & $r p(k-1)$ & $Q_{1}$ & $\sigma_{d}^{2}$ \\
\hline
\end{tabular}

$$
\begin{aligned}
& \text { onde: G.L. = graus de liberdada; } \\
& \text { Q.M. = quadrados médios; } \\
& E(Q . M .) \text { = esperança matemática dos quadrados médios: } \\
& r \text { = número de repetições ou blocos; } \\
& p=\text { número de progēnies de meios irmãos; } \\
& k=\text { número de bulbos avaliados por parcela; } \\
& Q_{3}=\text { quadrado médio entre progênies, ao nível de indivíduos: } \\
& Q_{2}=\text { quadrado médio do erro entre parcelas, ao nível de in } \\
& \text { divíduos; } \\
& Q_{1}=\text { quadrado médio dentro de percelas, ao nível de indiví } \\
& \sigma_{e}^{2}=\text { variância do erro ambiental entre parcelas dentro dos } \\
& \sigma_{p}^{2}=\text { variância genética entre progênies de meios irmãos,ao }
\end{aligned}
$$


Tabela 3 - Esquema da Anälise de Covariância, ao Nível de Indivíduos, no Delineamento em Blocos ao Acaso, e Respectivas Es peranças Matemáticas dos Produtos Médios, Segundo a Metodologia em KEMPTHORNE (1966), Considerando-se um Local.

\begin{tabular}{|c|c|c|}
\hline F.Variação & G.L. & $E(P M)$ \\
\hline Blocos & $p-1$ & - \\
\hline Progênies & $p-1$ & $\operatorname{cov}_{d(x, y)^{+k \operatorname{COV}_{e}}(x, y)^{+r k \operatorname{COV}} p(x, y)}$ \\
\hline $\begin{array}{l}\text { Erro entre } \\
\text { Parcelas }\end{array}$ & $(r-1)(p-1)$ & $\operatorname{cov}_{d(x, y)}+k \operatorname{Cov}_{e}(x, y)$ \\
\hline $\begin{array}{l}\text { Dentro de } \\
\text { Parcelas }\end{array}$ & $\operatorname{rp}(k-1)$ & $\operatorname{cov}_{d(x, y)}$ \\
\hline \multicolumn{3}{|c|}{$\begin{aligned} \text { onde: } r & =\text { número de repetições; } \\
p & =\text { número de progênies de meios irmãos; } \\
k & =\text { número de bulbos avaliados por parcela; } \\
P M & =\text { produto médio; } \\
E(P M) & =\text { esperança matemática dos produtos médios; }\end{aligned}$} \\
\hline \multicolumn{3}{|c|}{$\begin{array}{l}P M_{P(x, y)}=\text { produto médio entre progênies para oa caracteres } x \text { e } \\
P M_{e(x, y)}=\text { produto médio do erro entre parcelas, para os caracte }\end{array}$} \\
\hline $\operatorname{Cov}_{p(x, y)}=$ & $\begin{aligned} \text { covariância } \\
\\
\text { x e y, ao } n\end{aligned}$ & $\begin{array}{l}\text { genética entre progênies para os caracteres } \\
\text { vel de indivíduos; }\end{array}$ \\
\hline $\operatorname{cov}_{e(x, y)}=$ & $\begin{aligned} \text { covariância } \\
\text { caracteres }\end{aligned}$ & $\begin{array}{l}\text { do erro ambiental entre parcelas, para os } \\
\text { e y: }\end{array}$ \\
\hline $\operatorname{cov}_{d(x, y)}=$ & $\begin{array}{l}\text { covariância } \\
\text { las, para o }\end{array}$ & $\begin{array}{l}\text { fenotípica entre bulbos dentro das parce- } \\
\text { caracteres } x \mathrm{e} y \text {. }\end{array}$ \\
\hline
\end{tabular}




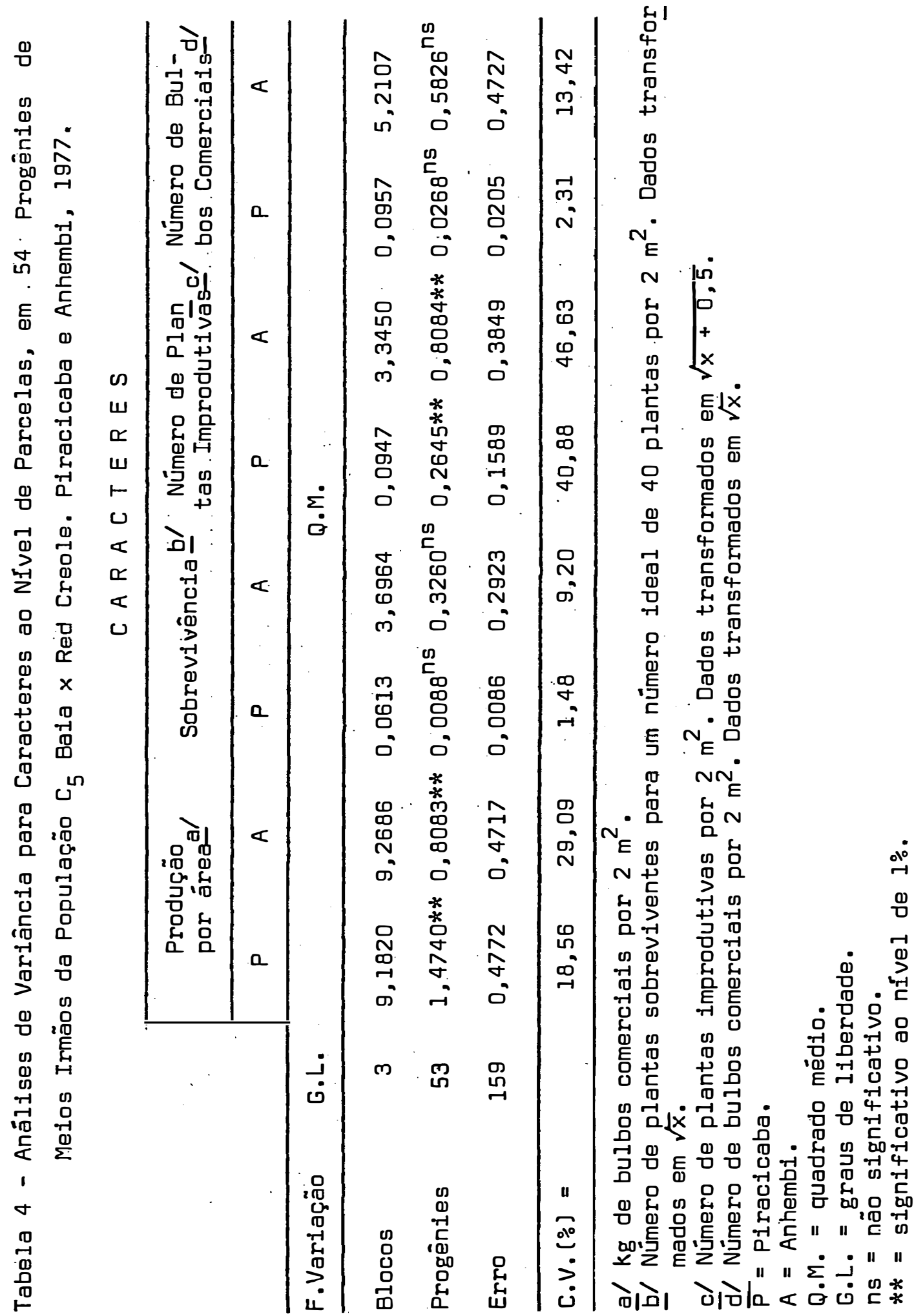


106.

Tabela 5 - Análises de Variāncia do Caráter Peso do Bulbo, ao Nível de Indivíduos, para 54 Progênies de Meios Irmãos da Popü lação $C_{5}$ Baia $\times$ Red Creole. Piracicaba e Anhembi, 1977.

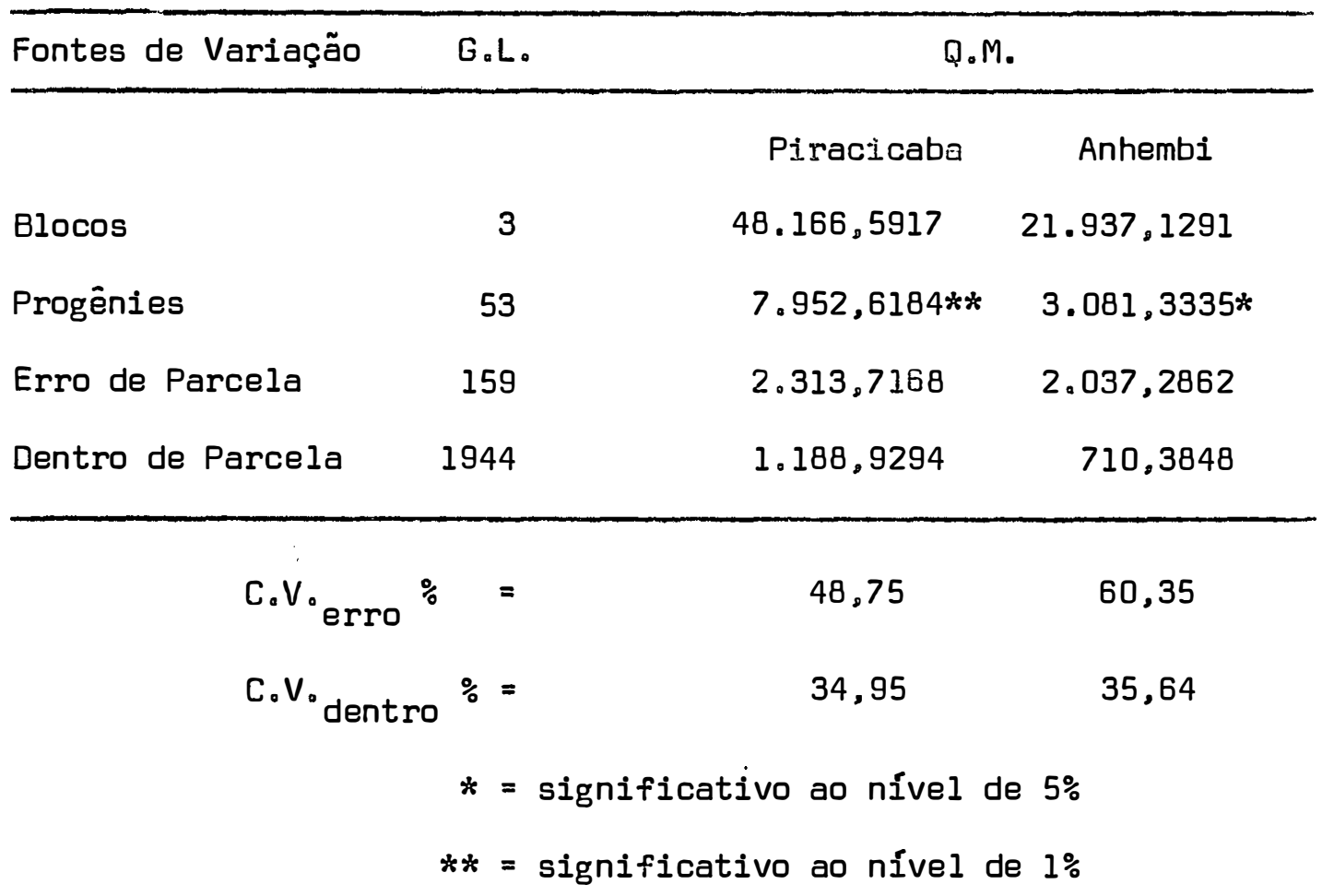


107.

Tabela 6 - Análises de Variância do Caráter Diâmetro de Bulbo, ao Nível de Indivíduos, em 54 Progênies de Meios Irmãos da População $C_{5}$ Baia $\times$ Red Creole. Piracicaba e Anhembi, 1977 .

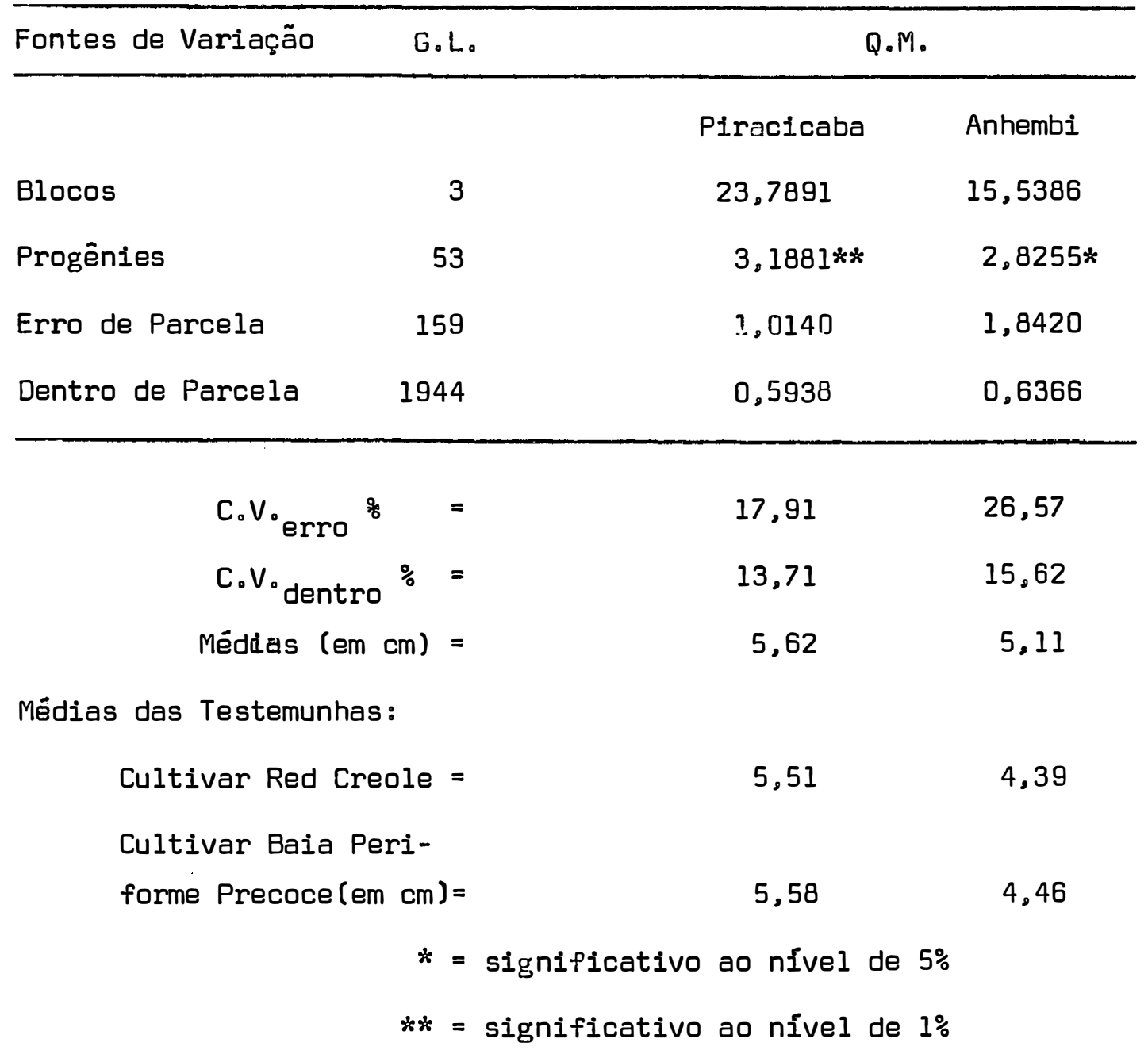


108 。

Tabela 7 - Análises de Variância do Caräter Indice de Formato, ao Nível de Indivíduos, de 54 Progênies de Meios Irmãos, da População $C_{5}$ Baia $\times$ Red Creole. Piracicaba e Anhembi, 1977 .

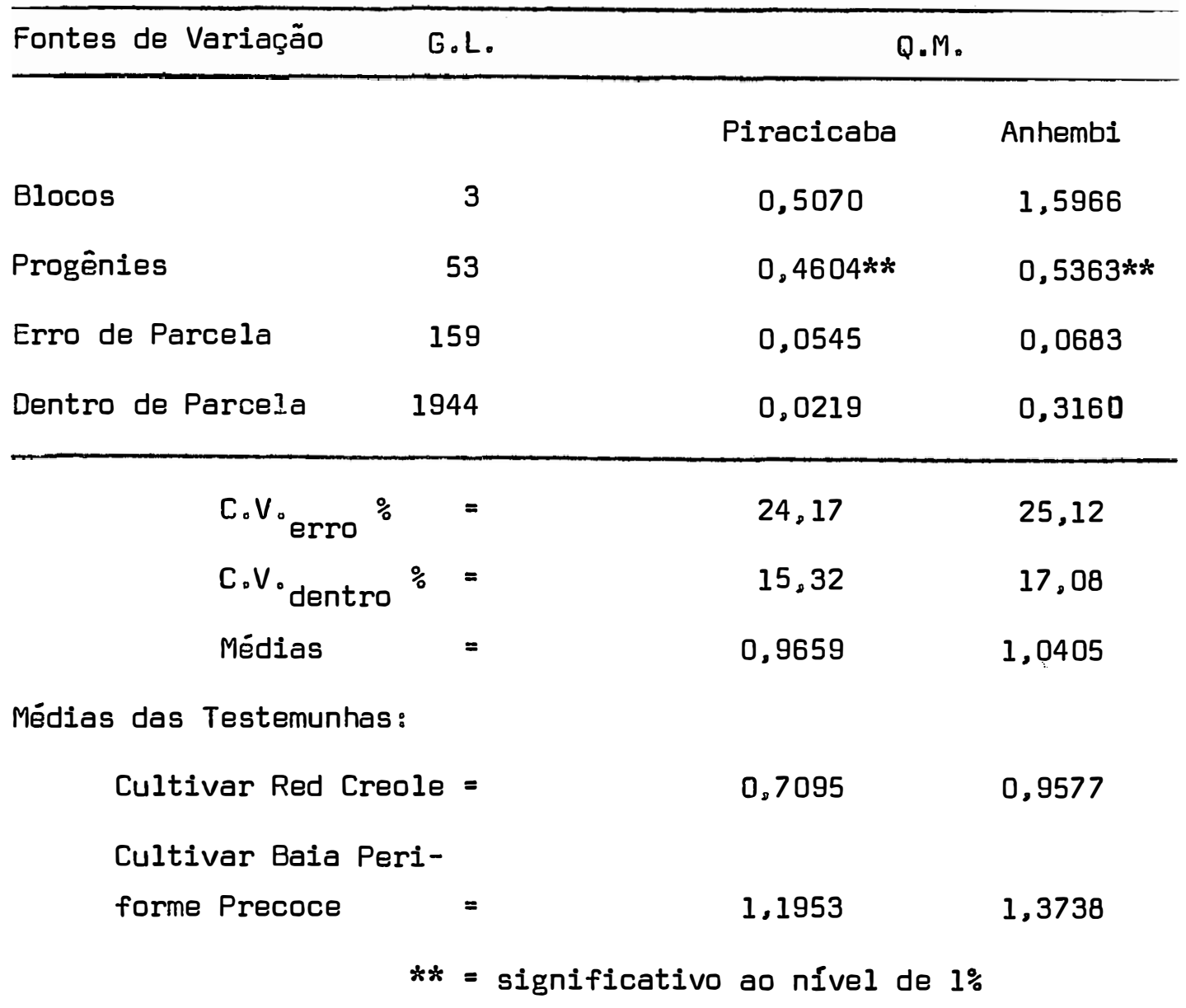


109.

Tabela 8 - Análises de Variância do Caráter Teor de Sólidos Solúveis, ao Nível de Indivíduos, de Progênies de Meios Irmãos da População $C_{5}$ Baia $\times$ Red Creole. Piracicaba e Anhembi。 1977.

\begin{tabular}{|c|c|c|c|}
\hline \multirow[t]{2}{*}{ Fontes de Variação } & \multirow[t]{2}{*}{ G.L. } & \multicolumn{2}{|c|}{ Q.M. } \\
\hline & & Piracicaba & Anhembi \\
\hline Blocos & 3 & 29,1349 & 7,7329 \\
\hline Progênies & 53 & $10,8365 * *$ & $8,9538 * *$ \\
\hline Erro de Parcela & 159 & 3,3021 & 3,1383 \\
\hline Dentro de Parcela & 1944 & 1,4787 & 1,4492 \\
\hline C.V.erro $\%$ & $=$ & 22,06 & 21,44 \\
\hline C.V.dentro & $\%=$ & 14.76 & 14,57 \\
\hline
\end{tabular}


Tabela 9 - Estimativas cios Componentes da Variância de Caracteres, ao Nível de Parcelas, Referentes a 54 Progênies de Meios Irmãos da População $C_{5}$ Baia $\times$ Red Creole. Piracicaba e Anhembi。1977.

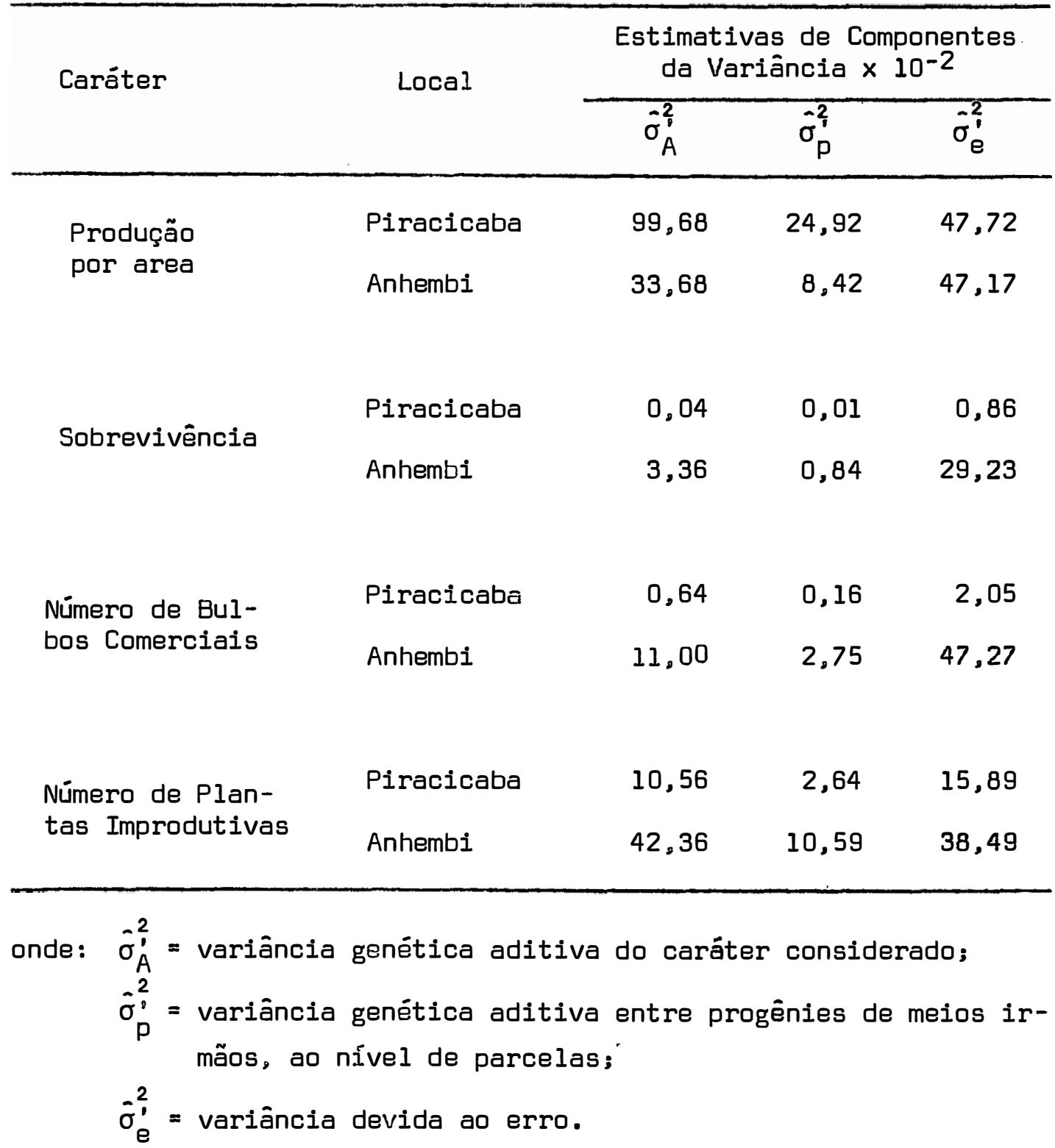


Tabela 10 - Estimativas do Coeficiente de Herdabilidade, Consideran do-se Seleção entre Médias de Progênies e do Progresso Genético Esperado de Caracteres ao Nível de Parcelas, Re ferentes a 54 Progênies de Meios Irmãos da População $C_{5}$ Baia $\times$ Red Creole. Piracicaba e Anhembi, 1977.

\begin{tabular}{|c|c|c|c|c|}
\hline Caráter & Local & $\hat{h}_{\bar{F}}^{2}=\%$ & $\hat{\Delta G} \%$ & $\mathrm{CV}_{\text {gen }}^{\prime}$ \\
\hline \multirow{2}{*}{$\begin{array}{l}\text { Produção } \\
\text { por área }\end{array}$} & Piracicaba & 67.63 & 19,41 & 13,41 \\
\hline & Anhembi & 41,64 & 13,96 & 12,30 \\
\hline \multirow{2}{*}{ Sobrevivência } & Piracicaba & 4,35 & 0,06 & 0,16 \\
\hline & Anhembi & 10,34 & 0,88 & 1,56 \\
\hline \multirow{2}{*}{$\begin{array}{l}\text { Número de Bul- } \\
\text { bos Comerciais }\end{array}$} & Piracicaba & 23,88 & 5,55 & 2,64 \\
\hline & Anhembi & 18,86 & 2,23 & 2,91 \\
\hline \multirow{2}{*}{$\begin{array}{l}\text { Número de Plan- } \\
\text { tas Improdutivas }\end{array}$} & Piracicata & 39,92 & $-18,07$ & 17.75 \\
\hline & Anhembi & 52,39 & $-31,16$ & 24,46 \\
\hline
\end{tabular}

onde: $\quad f_{F}^{2} \%=$ coeficiente de herdabilidade, considerando-se seleção entre médias de progênies;

$\hat{\Delta G^{\prime} \%=~ g a n h o ~ g e n e ́ t i c o ~ e s p e r a d o ~ c o m ~ s e l e c ̧ a ̃ o ~ e n t r e ~ p r o g e ̂ n i e s ~ d e ~}$ meios irmãos e com intensidade de seleção de $10 \%$, em ambos os sexos:

$\mathrm{CV}_{\text {gen }} \%$ coeficiente de variação genética expressa em porcentagem. 
Tabela 11 - Estimativas de Componentes de Variância de Caracteres do Bulbo, ao Nível de. Indivíduos, da População $C_{5}$ Baia $x$ Red Creole. Piracicaba e Anhembi, 1977.

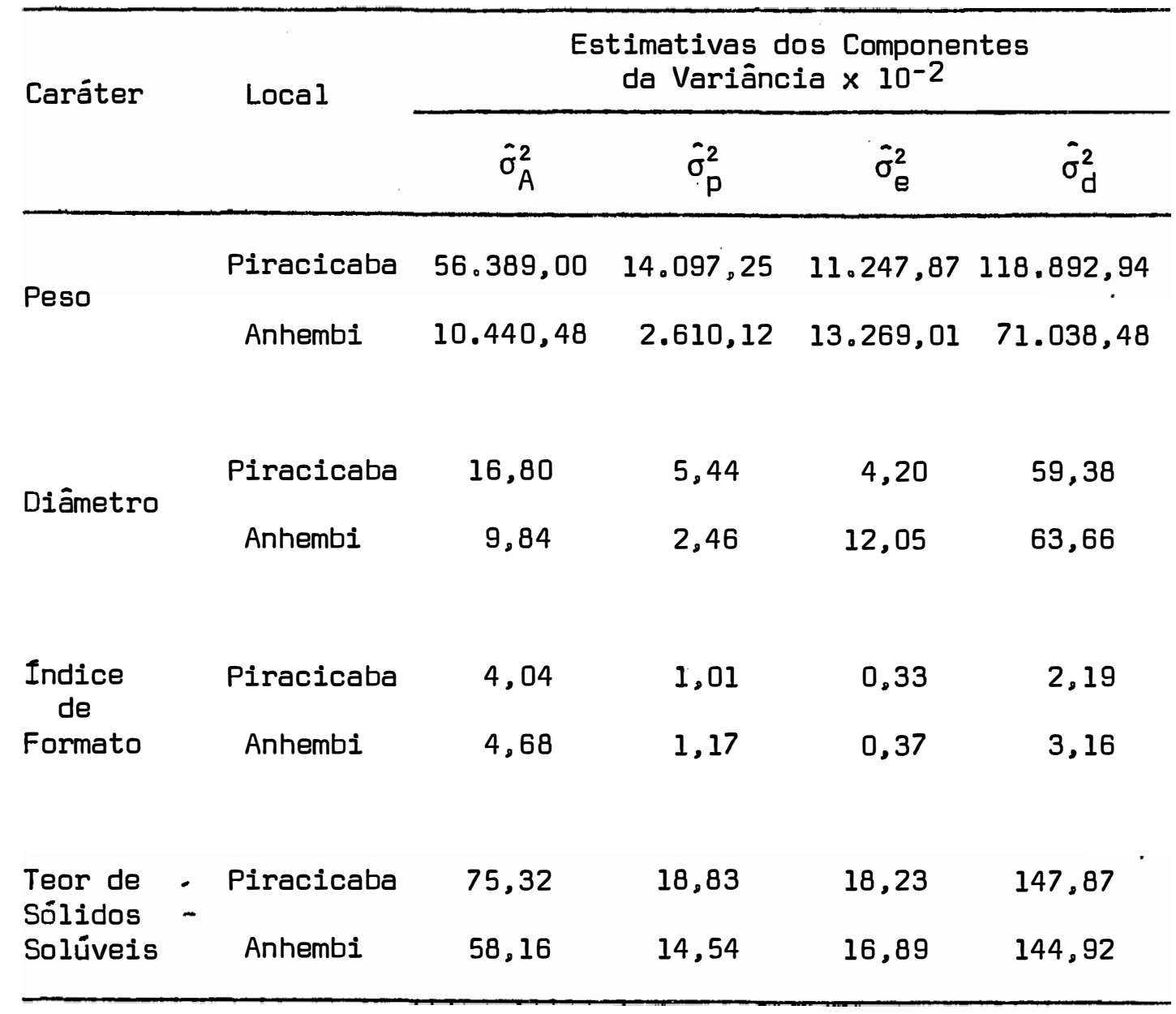

onde: $\tilde{\sigma}_{A}^{2}=$ variância genética aditiva, ao nível de indivíduos; $\hat{\sigma}_{p}^{2}=$ variância genética aditiva entre progênies de meios irmãos, ao nível de indivíduos;

$\hat{\sigma}_{e}^{2}=$ variância devida ao erro ambiental entre parcelas; $\hat{\sigma}_{d}^{2}=$ variância fenotípica entre plantas dentro de parcelas. 
Tabela 12 - Estimativas do Coeficiente de Herdabilidade e Progresso Genético Esperado para Caracteres do Bulbo, ao Nível de Indivíduos, da População $C_{5}$ Baia $\times$ Red Creole. Piracica ba e Anhembi。 1977.

\begin{tabular}{|c|c|c|c|c|c|}
\hline Caráter & Local & $f^{2} \%$ & $\hat{\Delta G}_{1} \%$ & $\hat{\Delta G}_{2} \%$ & CV ${ }_{\text {gen }} \%$ \\
\hline \multirow{2}{*}{ Peso } & Piracicaba & 39,09 & 21,07 & 15,79 & 12,03 \\
\hline & Anhembi & 12,01 & 6,63 & 4,51 & 6,83 \\
\hline \multirow{2}{*}{ Diâmetro } & Piracicaba & 24,34 & 5,04 & 4,78 & 4,15 \\
\hline & Anhembi & 12,59 & 3,05 & 2,30 & 3,07 \\
\hline \multirow{2}{*}{$\begin{array}{l}\text { Indice de } \\
\text { Formato }\end{array}$} & Piracicaba & (a) & 31,17 & 26,00 & 10,40 \\
\hline & Anhembi & 99,57 & 29,05 & 25,12 & 10,40 \\
\hline \multirow{2}{*}{$\begin{array}{l}\text { Teor de Sóli } \\
\text { dos Solúveis }\end{array}$} & Piracicaba & 40,73 & 9,41 & 7,16 & 5,18 \\
\hline & Anhembi & 32,98 & 7,42 & 5,57 & 4,61 \\
\hline
\end{tabular}

onde: $f^{2} \%=$ coeficiente de herdabilidade no sentido restrito, em por centagem:

$\hat{\Delta G}_{1} \%$ progresso genético esperado em porcentagem, com seleção massal estratificada, sendo cada bloco um estrato, em ambos os sexos e intensidade de seleção de $20 \%$;

$\hat{\Delta G}_{2} \%$ progresso genético esperado em porcentagem, com seleção massal estratificada, sendo cada parcela um estrato, em ambos os sexos e intensidade de seleção de $20 \%$

$(a)=0$ valor da estimativa foi superior a 1 , possivelmente de vido a amostragem insatisfatória; resultando uma variação muito pequena dentro de parcelas. 
Tabela 13 - Análises de Covariância para os Pares de Caracteres,aos Níveis de Parcelas, Referentes a 54 Progênies de Meios Irmãos da População $C_{5}$ Baia $\times$ Red Creole. Piracicaba e Anhembi, 1977.

PRODUTOS MEDIOS

\begin{tabular}{lcccc}
\hline Fontes de Variação & $G . L_{0}$ & $P+S$ & $P+N B C$ & $P+N P I$ \\
\hline Blocos & 3 & - & - & - \\
Progênies & 53 & 0,1850 & $-0,0003$ & 0,0718 \\
& & $(0,2851)$ & $(0,4619)$ & $(-0,2999)$ \\
Erro & 159 & 0,0151 & $-0,0195$ & $-0,1787$ \\
& & $(0,2550)$ & $(0,2985)$ & $(-0,1996)$ \\
\hline
\end{tabular}

PRODUTOS MEDIOS

\begin{tabular}{lcccc}
\hline Fontes de Variação & G.L. & $S+N B C$ & $S+N P I$ & $N B C+N P I$ \\
\hline Blocos & 3 & - & - & - \\
Progênies & 53 & 0,0117 & $-0,0035$ & $-0,0682$ \\
& & $(0,2984)$ & $(-0,0987)$ & $(-0,3527)$ \\
Erro & 159 & 0,0102 & $-0,0083$ & $-0,0436$ \\
& & $(0,3284)$ & $(-0,0597)$ & $(-0,1789)$ \\
\hline
\end{tabular}

onde: $P=$ produção por área:

$S$ = sobrevivência;

NBC = nümero de bulbos comerciais;

NPI = número de plantas improdutivas;

(a) = valores entre parênteses referem-se ao local Anhembi, os demais a Piracicaba. 
Tabela 14 - Estimativas dos Componentes dos Produtos Médios dos Pares de Caracteres, Avaliados ao Nível de Parcelas, de 54 Progênies de Meios Irmãos da População $C_{5}$ Baia $\times$ Red Creole. Piracicaba e Anhembi, 1977.

\begin{tabular}{|c|c|c|c|}
\hline \multirow{2}{*}{$\begin{array}{l}\text { Pares de } \\
\text { Caracteres }\end{array}$} & \multirow[b]{2}{*}{ Local } & \multicolumn{2}{|c|}{ Estimativas de Componentes dos PM } \\
\hline & & côv. & Côv' \\
\hline \multirow{2}{*}{$P-S$} & Piracicaba & 0,0008 & 0,0151 \\
\hline & Anhembi & 0,0075 & 0,2550 \\
\hline \multirow{2}{*}{ P-NBC } & Piracicaba & 0,0048 & $-0,0195$ \\
\hline & Anhembi & 0,0409 & 0,2985 \\
\hline \multirow{2}{*}{$P-N P I$} & Piracicaba & 0,0626 & $-0,1787$ \\
\hline & Anhembi & $-0,0251$ & $-0,1996$ \\
\hline \multirow{2}{*}{ S-NBC } & Piracicaba & 0,0004 & 0,0102 \\
\hline & Anhembi & $-0,0075$ & 0,3284 \\
\hline \multirow{2}{*}{ S-NPI } & Piracicaba & 0,0012 & $-0,0083$ \\
\hline & Anhembi & $-0,0098$ & $-0,0597$ \\
\hline \multirow{2}{*}{ NBC-NPI } & Piracicaba & $-0,0062$ & $-0,0436$ \\
\hline & Aninembi & $-0,0435$ & $-0,1789$ \\
\hline
\end{tabular}

onde: $P=$ produção por área:

$S=$ sobrevivência:

NBC = nümero de bulbos comerciais;

NPI = número de plantas improdutivas;

Cố ' = covariância genética aditiva entre progênies de meios irmãos: $\operatorname{côv}_{e}^{\prime}=$ covariância devida ao erro. 
116 .

Tabela 15 - Estimativas das Variāncias Fenotípicas (Dispostas na Dia gonal) e das Covariàncias Fenotípicas (Dispostas acima da Diagonal) entre Médias de Caracteres, Referentes a 54 Progênies de Meiós Irmãos da População $C_{5}$ Baia $\times$ Red Creole. Piracicaba e Anhembi, 1977.

\begin{tabular}{ccccc}
\hline Caracteres & $P$ & $S$ & NBC & NPI \\
\hline P & 0,3685 & 0,0046 & 0,0001 & 0,0180 \\
& $(0,2021)$ & $(0,0713)^{a}$ & $(0,1155)$ & $(-0,0248)$ \\
S & 0,0023 & 0,0030 & $-0,0009$ \\
& $(0,0815)$ & $(0,0746)$ & $(-0,0247)$ \\
NBC & & 0,0670 & $-0,0171$ \\
& & & $(0,1457)$ & $(-0,0882)$ \\
NPI & & & 0,0661 \\
& & & & $(0,2021)$ \\
\hline
\end{tabular}

onde: $P=$ produção por ärea:

$S$ = sobrevivência;

NBC = número de bulbos comerciais;

NPI = número de plantas improdutivas:

(a) = valores entre parênteses referem-se ao local Anhembi; os demais ao local Piracicaba. 
Tabela 16 - Estimativas dos Coeficientes de Correlação Fenotípica en tre Médias dos Caracteres ao Nível de Parcelas, de 54 Progênies de Meios Irmãos da População $C_{5}$ Baia $x$ Red Creole. Piracicaba e Anhembi. 1977.

\begin{tabular}{cccc}
\hline Caracteres & $S$ & NBC & NPI \\
\hline$P$ & $0,1616^{\mathrm{ns}}$ & $0,0020^{\mathrm{ns}}$ & $0,1200^{\mathrm{ns}}$ \\
& $(0,5553)^{a_{* *}}$ & $(0,6732) * *$ & $(-0,1227)^{\mathrm{ns}}$ \\
& & & \\
& & $0,7515 * *$ & $-0,0730^{\mathrm{ns}}$ \\
& $(0,6844)^{* * *}$ & $(-0,1923)^{\mathrm{ns}}$ \\
NBC & & $-0,8126 * *$ \\
& & $(-0,5140) * *$ \\
\hline
\end{tabular}

onde: $P=$ produção por àrea:

$S$ = sobrevivência;

NBC = número de bulbos comerciais;

NPI = número de plantas improdutivas:

** = significativo ao nível de $1 \%$ de probabilidade;

$n s$ = não significativo;

(a) = os valores entre parênteses referem-se ao local Anhembi; os demais, a Piracicaba. 
Tabela 17 - Estimativas de 1/4 das Variâncias Genéticas Aditivas(Dis postas na Diagonal) e das Covariâncias Genéticas Aditivas (Dispostas acima da Diagonal) dos Caracteres, ao $\mathrm{Ni}$. vel de Parcelas,de. 54 Progênies de Meios Irmãos da População $C_{5}$ Baia x Red Creole. Piracicaba e Anhembi, 1977.

\begin{tabular}{ccccc}
\hline Caracteres & $P$ & $S$ & NBC & NPI \\
\hline$P$ & 0,2492 & 0,0008 & 0,0048 & 0,0626 \\
& $(0,0842)^{a}$ & $(0,0075)$ & $(0,0409)$ & $(-0,0251)$ \\
& & & & \\
$S$ & 0,0001 & 0,0004 & 0,0012 \\
& $(0,0084)$ & $(-0,0075)$ & $(-0,0098)$ \\
NBC & & 0,0016 & $-0,0062$ \\
& & & $(0,0275)$ & $(-0,0435)$ \\
NPI & & & 0,0264 \\
& & & & $(0,1059)$ \\
\hline
\end{tabular}

onde: $P$ = produção por àrea:

$S$ = sobrevivência;

$\mathrm{NBC}=$ nümero de bulbos comerciais:

NPI = número de plantas improdutivas;

(a) = os valores entre parênteses referem-se ao local Anhembi: os demais, a Piracicaba. 
Tabela 18 - Estimativas dos Coeficientes de Correlação Genética Adi tiva dos Caracteres Avaliados ao Nível de Parcelas, de 54 Progênies de Meios Irmãos da População $C_{5}$ Baia $\times$ Red Creole. Piracicaba e Anhembi, 1977.

\begin{tabular}{cccc}
\hline Caracteres & S & NBC & NPI \\
\hline P & 0,1678 & 0,2404 & 0,7721 \\
& $(0,2829)^{a}$ & $(0,8667)$ & $(-0,2655)$ \\
& & & \\
& & 0,9375 & 0,7386 \\
& & $(-0,4935)$ & $(-0,3269)$ \\
NBC & & $-0,9463$ \\
\end{tabular}

onde: $P=$ produção por área;

$S$ = sobrevivência:

$\mathrm{NBC}=$ número de bulbos comerciais;

NPI = número de plantas improdutivas;

(a) = os valores entre parênteses referem-se ao local Anhembi; os demais, a Piracicaba. 
Tabela 19 - Análises de Covariância Para os Pares Formados com os Ca racteres de Bulbo, ao Nível de Indivíduos, Referentes a 54 Progênies de Meios Irmãos da População $C_{5}$ Baia $\times$ Red Creole. Piracicaba e Anhembi, 1977.

PRODUTOS MEDIOS

\begin{tabular}{lcccc}
\hline Fontes de Variação & G.Lo & $P e+D$ & $P e+I F$ & $P e+S S$ \\
\hline Progênies & 53 & $-67,9792$ & $-174,1196$ & $-214,5509$ \\
& & $(117,7977)$ & $(54,0264)$ & $(1,7833)$ \\
Erro de Parcela & 159 & 25,6692 & 16,2841 & $-70,6438$ \\
& & $(90,7609)$ & $(39,7623)$ & $(32,5957)$ \\
Dentro de Parcela & 1944 & $-6,9697$ & $-48,6282$ & $-36,9411$ \\
& & $(-21,1426)$ & $(-10,8774)$ & $(-14,4456)$ \\
\hline
\end{tabular}

PRODUTOS MERIOS

\begin{tabular}{lcccc}
\hline Fontes de Variação & G.L. & $D+I F$ & $0+S S$ & IF + SS \\
\hline Progênies & 53 & $-0,3712$ & 0,5682 & $-1,0571$ \\
& & $(-0,6373)$ & $(-0,5851)$ & $(-0,3284)$ \\
Erro de Parcela & 159 & $-0,0280$ & 0,0697 & $-0,0756$ \\
& & $(-0,2156)$ & $(0,5465)$ & $(0,0809)$ \\
Dentro de Parcela & 1944 & $-0,0734$ & $-0,1512$ & $-0,0093$ \\
& & $(0,0992)$ & $(-0,1794)$ & $(0,0238)$ \\
\hline
\end{tabular}

onde: G.L: = graus de liberdade;

$$
\begin{aligned}
\mathrm{Pe}= & \text { peso de bulbo; } \\
D= & \text { diâmetro de bulbo: } \\
\mathrm{IF}= & \text { indice de formato: } \\
\mathrm{SS}= & \text { teor de sólidos solúveis: } \\
(\mathrm{a})= & \text { os valores entre parênteses correspondem ao local Anhem } \\
& \text { bi: os demais, a Piracicaba. }
\end{aligned}
$$


Tabela 20 - Estimativas de Componentes dos Produtos Médios dos Pares de Caracteres ao Nivivel de Indivíduos, Referentes a 54 Progênies de Meios Irmãos da População $c_{5}$ Baia $\times$ Red Creole. Piracicaba e Anhembi, 1977.

\begin{tabular}{|c|c|c|c|c|c|}
\hline \multirow{2}{*}{$\begin{array}{l}\text { Pares de } \\
\text { Caracteres }\end{array}$} & \multirow{2}{*}{ Local } & \multicolumn{4}{|c|}{ Estimativas dos Componentes dos PM } \\
\hline & & $\operatorname{cov}_{A}$ & côv & côv & côv \\
\hline \multirow{2}{*}{ Pe-D } & Piracicaba & $-9,3648$ & $-2,3412$ & 3,2639 & $-6,9697$ \\
\hline & Anhembi & 0,6759 & 0,6759 & 11,1904 & $-21,1426$ \\
\hline \multirow{2}{*}{$\mathrm{Pe}-\mathrm{IF}$} & Piracicaba & $-19,0404$ & $-4,7601$ & 6,4912 & $-48,6282$ \\
\hline & Anhembi & 1,4264 & 0,3566 & 5,0640 & $-10,8774$ \\
\hline \multirow{2}{*}{ Pe-SS } & Piracicaba & $-14,3907$ & $-3,5977$ & $-3,3703$ & $-36,9411$ \\
\hline & Anhembi & $-3,0812$ & $-0,7703$ & 4,7041 & $-14,4456$ \\
\hline \multirow{2}{*}{$D-I F$} & Piracicaba & $-0,0343$ & $-0,0086$ & 0,0045 & $-0,0734$ \\
\hline & Anhembi & $-0,0420$ & $-0,0105$ & $-0,0315$ & 0,0992 \\
\hline \multirow{2}{*}{ D-SS } & Piracicaba & 0,0499 & 0,0125 & 0,0221 & $-0,1512$ \\
\hline & Anhembi & $-0,1132$ & $-0,0283$ & 0,0726 & $-0,1794$ \\
\hline \multirow{2}{*}{ IF-SS } & Piracicaba & $-0,0980$ & $-0,0245$ & $-0,0066$ & $-0,0093$ \\
\hline & Anhembi & $-0,0409$ & $-0,0102$ & 0,0570 & 0,0238 \\
\hline
\end{tabular}

onde: $\mathrm{Pe}=$ peso de bulbo;

$D=$ diâmetro de bulbo;

IF = Índice de formato;

SS = teor de sólidos solüveis: Côv $_{A}=\begin{gathered}\text { covariância genética aditiva entre caracteres ao nível de } \\ \text { indivíduos; }\end{gathered}$

CÔV ${ }_{p}=$ covariância genética aditiva entre progênies para os caracteres, ao nível de indivíduos:

Côv $_{e}=$ covariância do erro ambiental entre parcelas;

Côv $_{\mathrm{d}}=$ covariância fenotípica entre bulbos dentro de parcelas. 
Tabela 21 - Estimativas das Variàncias Fenotípicas (Dispostas na Dia gonal) e Covariâncias Fenotípicas (Dispostas acima da Diagonal) entre Caracteres de Bulbo, ao Nível de Indiví duos, Relativas a 54 Progênies de Meios Irmãos da População $C_{5}$ Baia $\times$ Red Creole. Piracicabe e Anhembi, 1977.

\begin{tabular}{ccccc}
\hline Caracteres & Pe & D & IF & SS \\
\hline Pe & 1422,3806 & $-6,0470$ & $-46,8971$ & $-43,9091$ \\
& $(869,1761)^{a}$ & $(-9,2763)$ & $(-5,4568)$ & $(-10,5118)$ \\
& & & & \\
D & 0,6902 & $-0,0775$ & $-0,1166$ \\
& $(0,7817)$ & $(0,0572)$ & $(-0,1351)$ \\
IF & & 0,0353 & $-0,0404$ \\
& & & $(0,0470)$ & $(0,0706)$ \\
& & & & 1,8493 \\
SS & & & 1,7635 \\
\hline
\end{tabular}

onde: $\mathrm{Pe}=$ peso de bulbo:

$D$ = diâmetro de bulbo:

IF = Indice de formato:

SS = teor de sólidos solúveis;

(a) = os valores entre parênteses referem-se ao local Anhembi: os demais, a Piracicaba. 
Tabela 22 - Estimativas de Coeficientes de Correlação Fenotípica en tre Caracteres ao Nível de Individuos, Relativas a $\overline{54}$ Progênies de Meios Irmãos da População $C_{5}$ Baia $x$ Red Creole. Piracicaba e Anhembi, 1977.

\begin{tabular}{cccc}
\hline Caracteres & D & IF & SS \\
\hline Pe & $-0,1930$ & $-b$ & $-0,8561$ \\
& $(-0,3559)^{a}$ & $(-0,8538)$ & $(-0,2685)$ \\
D & & $-0,4965$ & $-0,1032$ \\
& & $(0,2991)$ & $(-0,1151)$ \\
IF & & $-0,1581$ \\
& & $(0,1554)$ \\
\hline
\end{tabular}

onde: $\mathrm{Pe}=$ peso de bulbo:

$D=$ diâmetro de bulbo:

IF = Índice de formato:

SS = teor de sólidos solúveis:

(a) = os valores entre parênteses referem-se ao local Anhembi: os demais, a Piracicaba;

(b) = valor acima de 1 , relacionado a estimativas possivelmente erradas, devido a amostragem insuficiente. 


\begin{abstract}
Tabela 23 - Estimativas das Variâncias Genéticas Aditivas (Dispostas na Diagonal) e Covariâncias Genéticas Aditivas (Dis postas acima da Diagonal) entre Caracteres de Bulbo, ao Nível de Indivíduos, Relativas a 54 Progênies de Meios Irmãos da População $C_{5}$ Baia x Red Creole. Piracicaba e Anhembi, 1977 .
\end{abstract}

\begin{tabular}{ccccc}
\hline Caracteres & Pe & D & IF & SS \\
\hline Pe & 563,8900 & $-9,3648$ & $-19,0404$ & $-14,3907$ \\
& $(104,4048)^{a}$ & $(0,6759)$ & $(1,4264)$ & $(-3,0812)$ \\
& & & & \\
& & 0,1680 & $-0,0344$ & 0,0499 \\
& $(0,0984)$ & $(-0,0420)$ & $(-0,1132)$ \\
IF & & $-0,0404$ & $-0,0980$ \\
& & & $(0,0468)$ & $(-0,0409)$ \\
SS & & & 0,7532 \\
& & & & $(0,5816)$ \\
\hline
\end{tabular}

onde: $\mathrm{Pe}=$ peso de bulbo;

$D=$ diämetro de bulbo;

IF = indice de formato;

SS = teor de sólidos solúveis;

(a) = os valores entre parênteses referem-se ao local Anhembi; os demais, a Piracicaba. 
Tabela 24 - Estimativas de Coeficientes de Correlação Genética Aditiva entre Caracteres ao Nível de Indivíduos, Relativas a 54 Progênies de Meios Irmãos da População $C_{5}$ Baia $x$ Red Creole. Piracicaba e Anhembi, 1977.

\begin{tabular}{crc}
\hline Pares de Caracteres & $\begin{array}{c}\text { Piracicaba } \\
\left(\hat{r}_{A} \pm \hat{\sigma}_{\hat{r}_{A}}\right)\end{array}$ & $\begin{array}{c}\text { Anhembi } \\
\left(\hat{r}_{A} \pm \hat{\sigma}_{\hat{r}_{A}}\right)\end{array}$ \\
\hline Pe-D & $-0,9622 \pm 0,0029$ & $-0,2529 \pm 0,0574$ \\
Pe-IF & $--\quad \pm \quad-\quad a$ & $-0,6453 \pm 0,0214$ \\
Pe-SS & $-0,6983 \pm 0,0175$ & $-0,3954 \pm 0,0407$ \\
D-IF & $-0,4175 \pm 0,0245$ & $-0,6189 \pm 0,0374$ \\
D-SS & $-0,1401 \pm 0,0376$ & $-0,4732 \pm 0,0370$ \\
IF-SS & $-0,6495 \pm 0,0105$ & $-0,2480 \pm 0,0267$ \\
\hline
\end{tabular}

onde: $\mathrm{Pe}=$ peso de bulbo:

$D=$ diâmetro de bulbo;

IF = Indice de formato:

SS = teor de sólidos solúveis;

(a) = valor obtido > 1; relacionado, possivelmente, a estimati vas erradas devido a amostragem não satisfatória para um dos caracteres;

$\hat{r}_{A}=$ coeficiente de correlação genética aditiva, ao nível de indivíduos:

$\begin{aligned} \bar{\sigma}_{\hat{\Gamma}_{A}}= & \text { desvio padrão do coeficiente de correlação genética adi- } \\ & \text { tiva, ao nível de indivíduos. }\end{aligned}$ 
126.

APENDICE 2

$F$ I G U R A S 


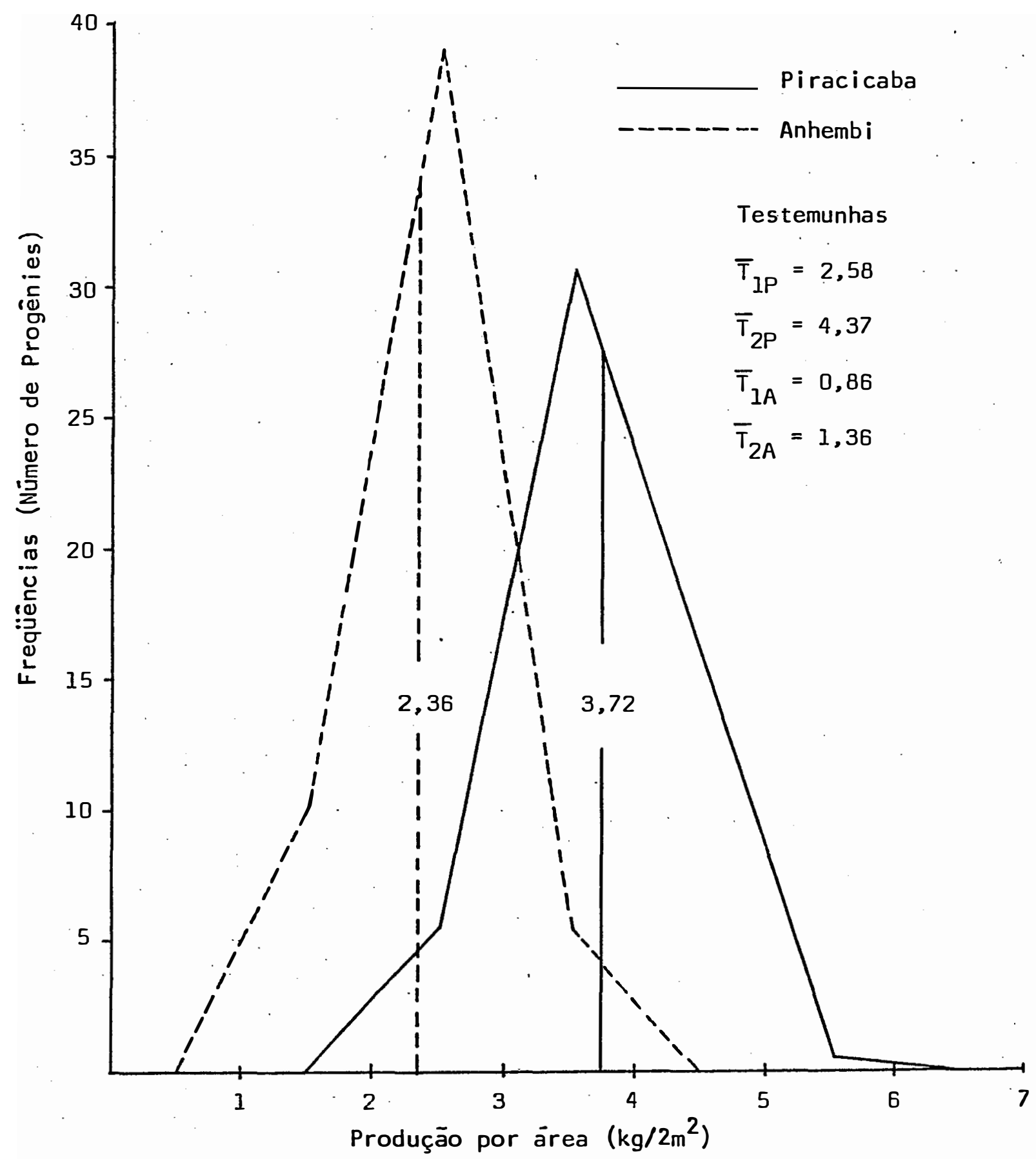

Fig. 1 - Distribuições das freqüências das produções por área, das 54 Progênies de meios irmãos da população $C_{5}$ Baia $\times$ Red Creole. Piracicaba e Anhembi, 1977 ( $T_{1}=$ média da cultivar . Red Creole; $\bar{T}_{2}=$ média da cultivar Composto Baia; P = Pira cicaba e $A=$ Anhembi $)$. 


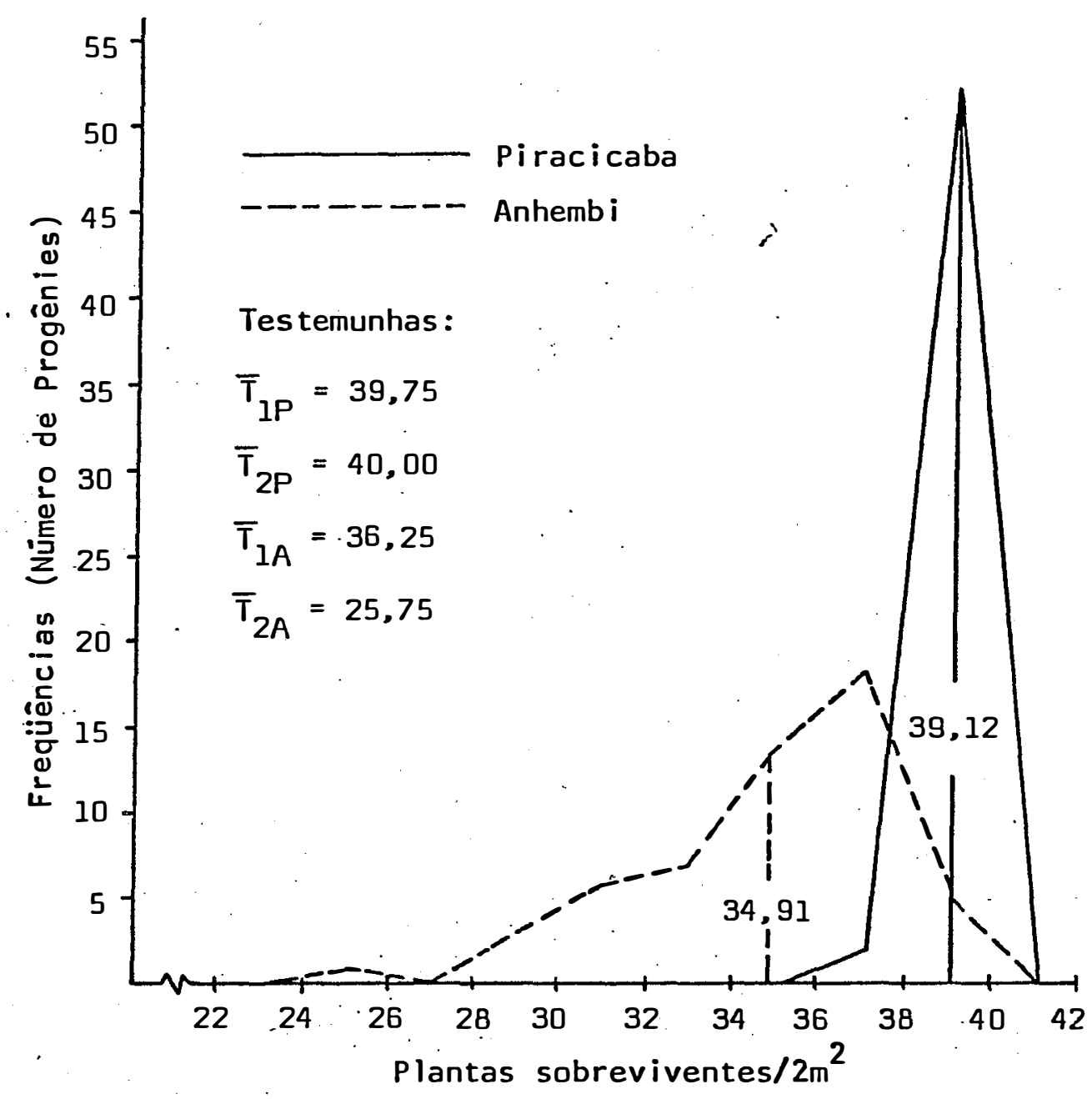

Fig. 2 - Distribuições das freqüēncias do carātèr sobrevivēncia,das 54 Progēnies de meios irmãos da população $C_{5}$ Baia $\times$ Red Creole. Piracicaba e Anhembi, 1977. (Dados não transformados e $\bar{T}_{1}=$ média dạ cultivar Red Creole; $\bar{T}_{2}=$ média da cul tivar Composto Baia; $P=$ Piracicaba; $A=$ Anhembi). 
129.

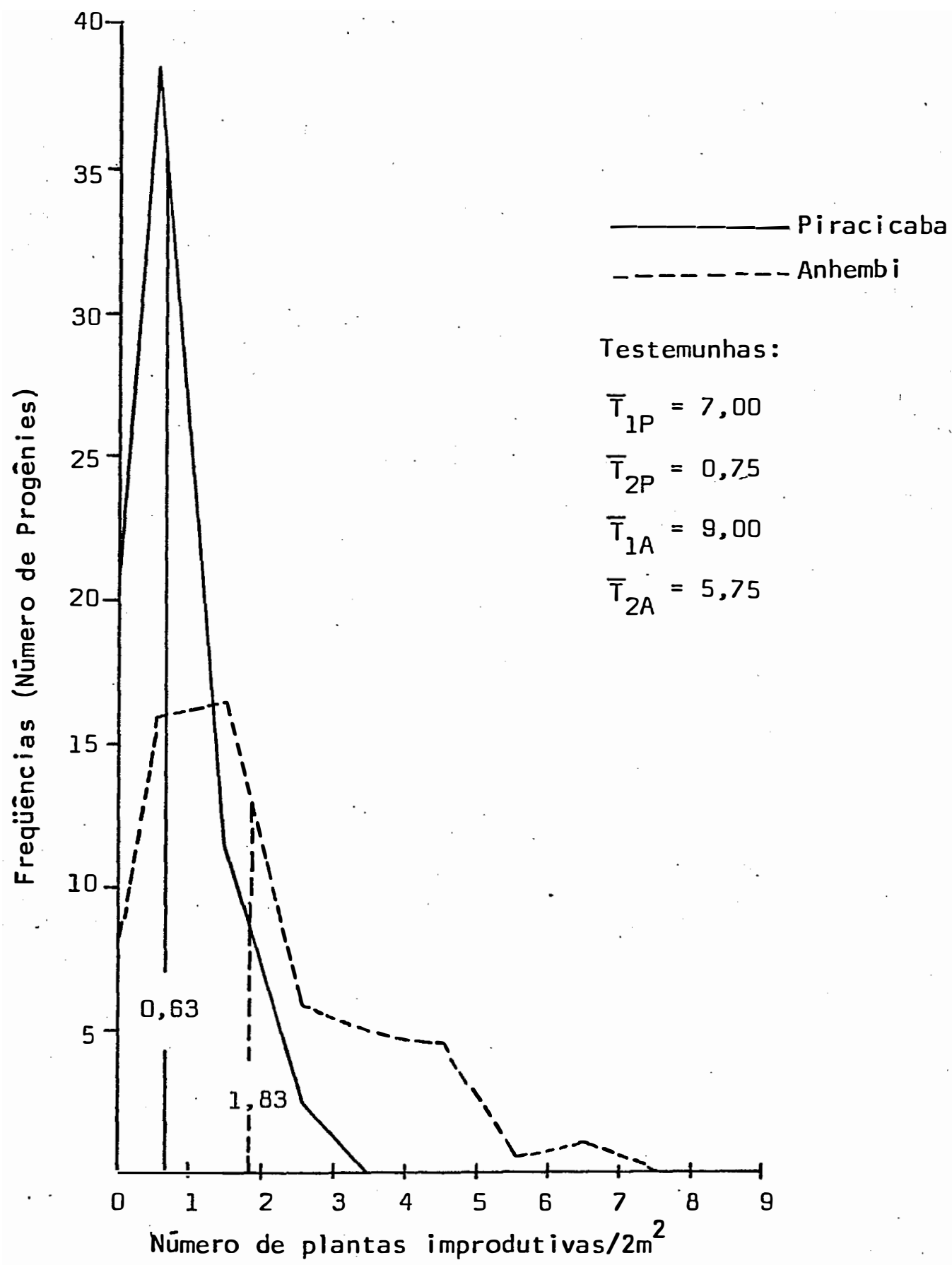

Fig. 3 - Distribuições das freqüências do número de plantas improdutivas, das 54 Progénies de meios irmãos da população $C_{5}$ Baia x Red Creole. Piracicaba e Anhembi, 1977. CDados näo transformados: $\bar{T}_{j}=$ média da cultivar Red Creole; $\bar{T}_{2}=$ mé dia da cultivar Composto Baia; $P=$ Piracicaba e $A=$ Anhembi). 


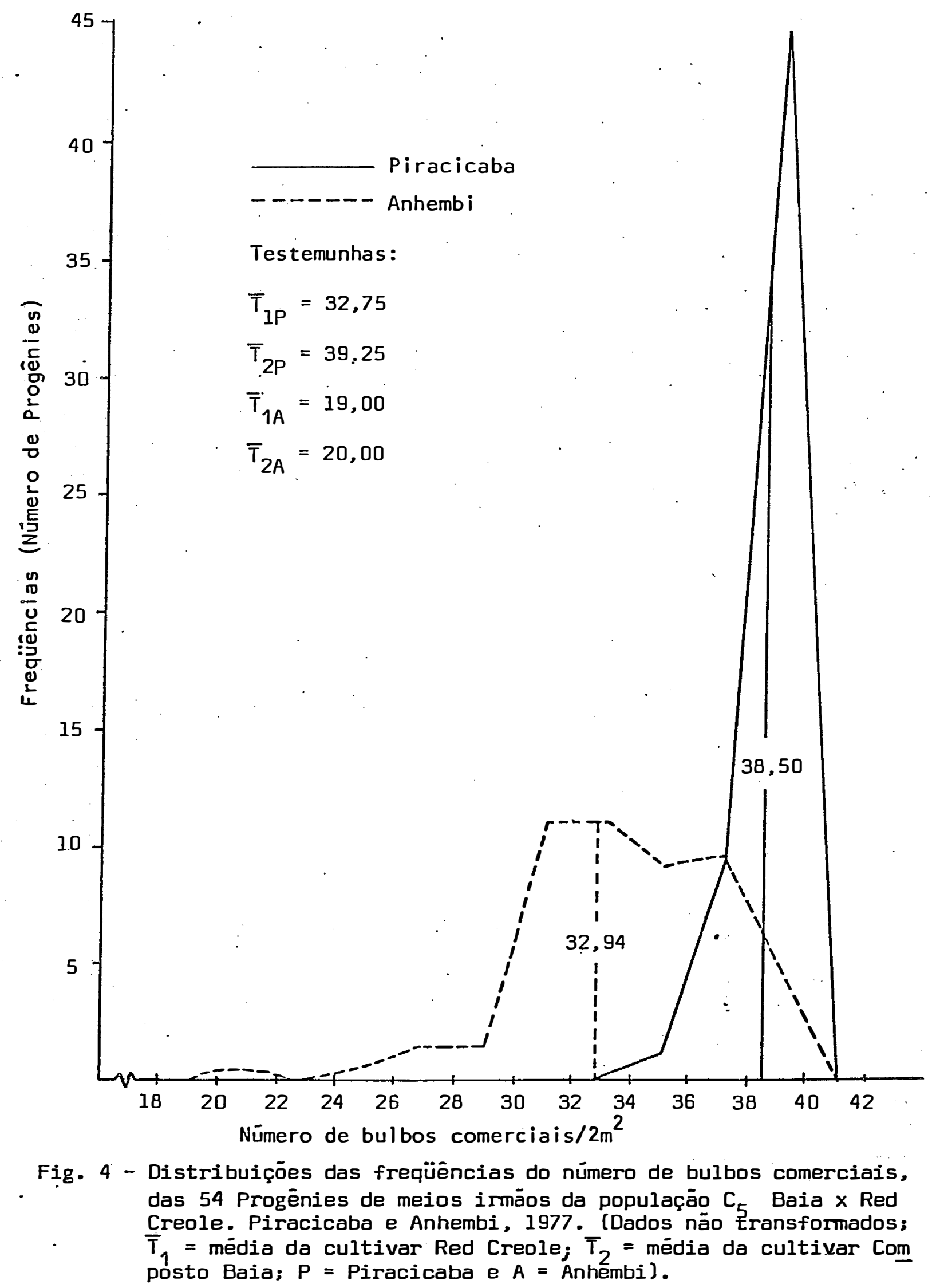




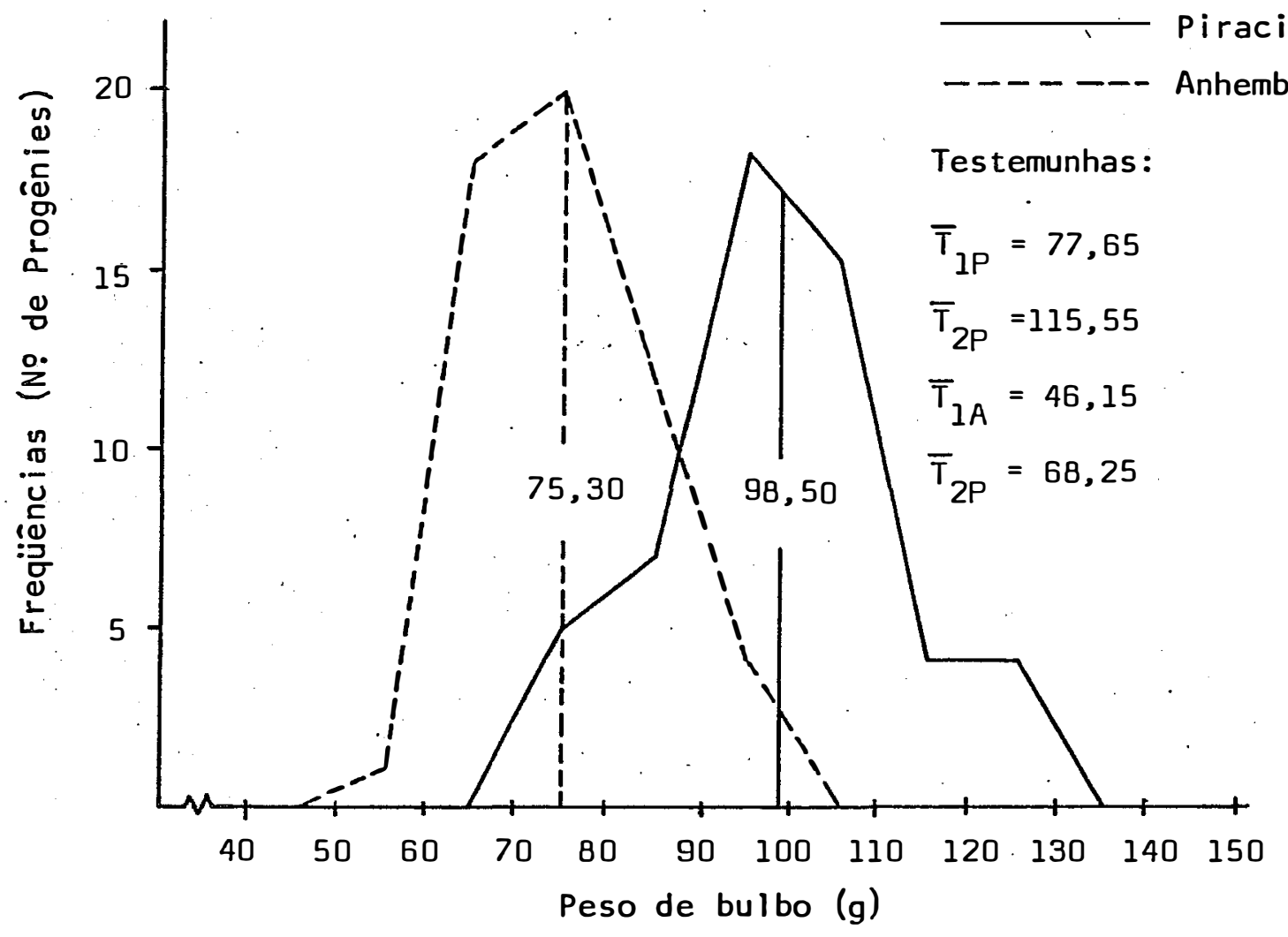

Fig. 5 - Distribuiçōes das freqüēncias do peso de bulbo, em gramas.

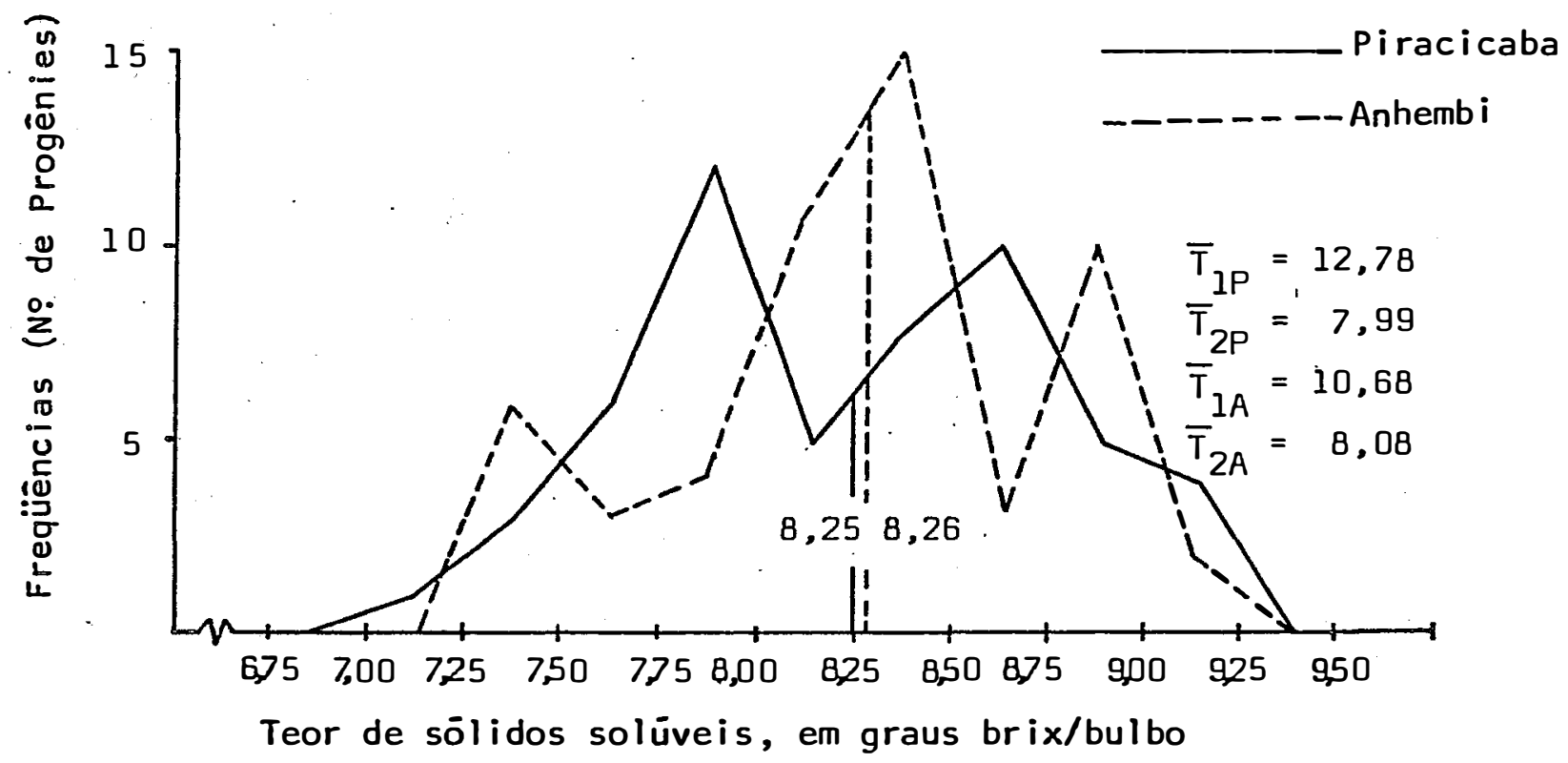

Fig. 6 - Distribuições de freqüèncias dos teores de sólidos solúveis por bulbo, em graus brix, das 54 Progênies de meios irmãos da população $C_{5}$ Baia $\times$ Red Creole. Piracicaba e Antiembi, 1977. (Obtido de amostra de dez bulbos por parcela; $\bar{T}_{\text {, }}=\mathrm{me}$ dia da cultivar Red Creole; $\bar{T}_{2}=$ média da cultivar Bala Com posto Baia; $P$.= Piracicaba e $\AA=$ Anhembi). 

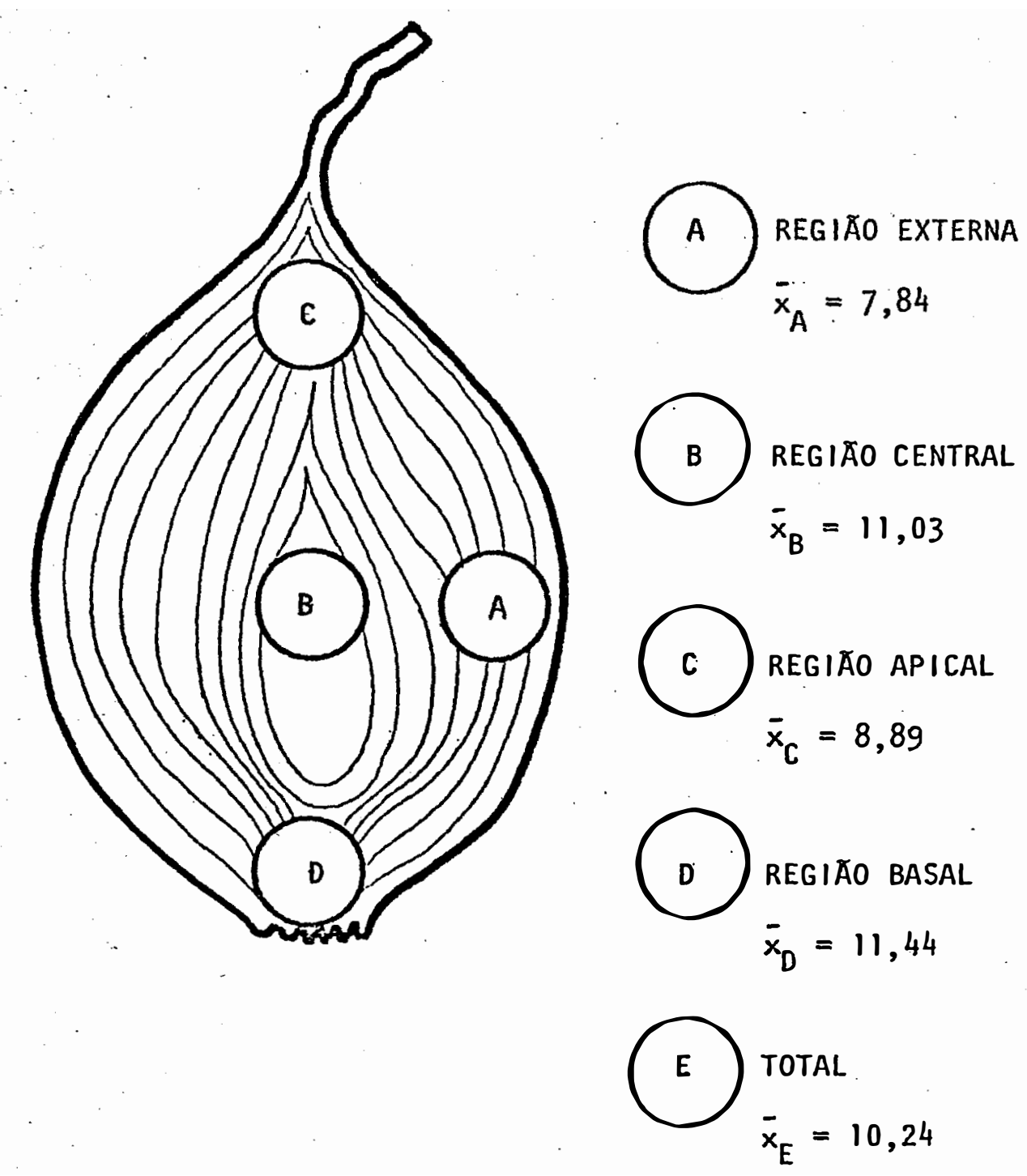

\footnotetext{
Fig. 7 - Gradiente do teor de sólidos solúveis no bulbo de cebola [em graus brix].
} 